\title{
THE RELATIONSHIP BETWEEN JOB SATISFACTION AND THE PERCEPTION OF ADMINISTRATIVE SUPPORT AMONG EARLY CAREER SECONDARY CHORAL MUSIC EDUCATORS
}

by

VICKI DOROTHY BAKER, B.A., M.A.

A DISSERTATION

IN

FINE ARTS
Submitted to the Graduate Faculty of Texas Tech University in
Partial Fulfillment of the Requirements for the Degree of

\section{DOCTOR OF PHILOSOPHY}

Approved

Janice Killian

Chairperson of the Committee

Brent Cejda

Linda Donahue

Jason Sifford

Bruce Wood

\author{
Accepted \\ John Borrelli \\ Dean of the Graduate School
}

May, 2005 


\section{ACKNOWLEDGEMENTS}

I would like to express my appreciation to Dr. Janice Killian for her inspiration, encouragement, and many hours of consultation and assistance. Her wisdom and expertise have been invaluable.

To my precious husband, Mark, I offer my deepest level of gratitude for being my patron and supporter. Thank you for walking by my side throughout my doctoral journey.

I offer a special word of thanks to Michael Vance for sharing his knowledge and insight as an administrator.

Thanks to all of the early career secondary choral directors and principals who participated in this study. This dissertation would not have been possible without your assistance. 


\section{TABLE OF CONTENTS}

ACKNOWLEDGEMENTS ................................................ ii

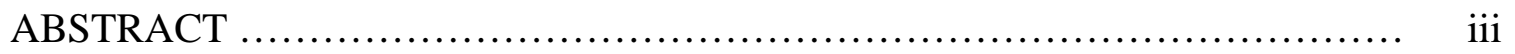

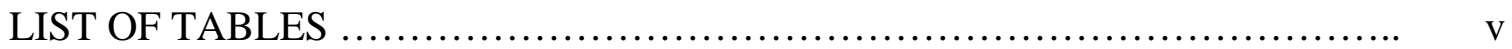

\section{CHAPTER}

I. $\quad$ ORIENTATION TO THE STUDY $\ldots \ldots \ldots \ldots \ldots \ldots \ldots \ldots \ldots \ldots \ldots . \ldots \ldots$

Statement of the Problem ................................ 1

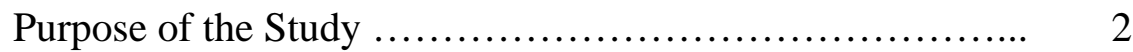

Research Questions ..................................... 3

Contribution and Significance of Study $\ldots \ldots \ldots \ldots \ldots \ldots \ldots \ldots . \quad 3$

Limitations of the Study ................................. 4

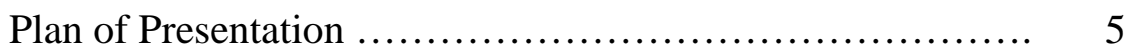

II. REVIEW OF THE LITERATURE ............................ 6

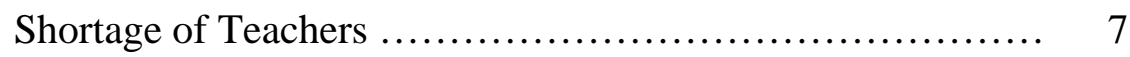

Rates of Teacher Attrition $\ldots . \ldots \ldots \ldots \ldots \ldots \ldots \ldots \ldots \ldots \ldots . . \ldots$

Impact of Teacher Attrition ............................ 12

Causes of Teacher Attrition .............................. 15

Administrative Support ............................... 21

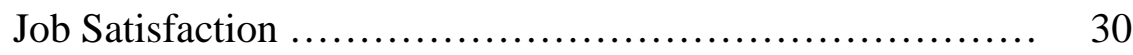

III. DESIGN AND METHODOLOGY OF THE STUDY .............. 35

Research Questions ..................................... 35

Design of the Study ................................. 36 
Questionnaire Components .......................... 36

Pilot Study of the Instrument .......................... 44

Selection of Subjects ................................. 44

Administration of the Survey $\ldots \ldots \ldots \ldots \ldots \ldots \ldots \ldots \ldots \ldots \ldots \ldots, 46$

Data Analysis ....................................... 46

IV. $\quad$ RESULTS ............................................... 48

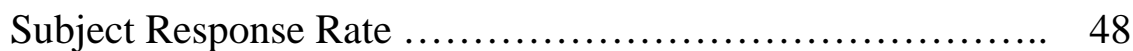

Demographic Findings .............................. 50

Teacher Job Satisfaction $\ldots \ldots \ldots \ldots \ldots \ldots \ldots \ldots \ldots \ldots \ldots \ldots . \ldots \ldots$

Methods of Professional Assistance ......................... 95

Comparison of Teacher and Principal Perception of

Professional Assistance

Teacher Attrition and Retention ........................ 158

Teacher Intention to Stay or Leave Current

Teaching Position ...................................... 173

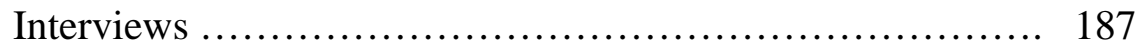

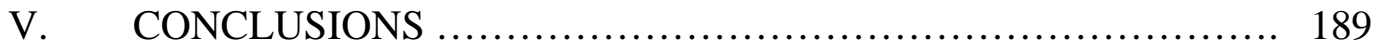

Discussion of Major Findings ........................ 189

Teacher Job Satisfaction ............................... 190

Methods of Professional Assistance ........................ 193

Teacher Attrition and Retention ........................ 193

Teacher Intention to Stay or Leave Current

Teaching Position ................................... 202

Role of Administrators ............................... 204 
A. THE QUESTIONNAIRE

B. EARLY CAREER SECONDARY CHORAL MUSIC TEACHER SURVEY

C. UNIVERSITY INTERSCHOLASTIC LEAGUE SCHOOL CONFERENCE POPULATION

D. TEXAS EDUCATION AGENCY SCHOOL DISTRICT CATEGORIES

E. EARLY CAREER TEACHER QUESTIONNAIRE COVER LETTER

F. PRINCIPALS OF EARLY CAREER TEACHERS COVER LETTER

G. OTHER FACTORS LEADING TO GREATER JOB SATISFACTION

H. OTHER REASONS FOR STAYING IN THE TEACHING PROFESSION

I. OTHER REASONS FOR CHANGING SCHOOLS 242

J. TRANSCRIPT OF INTERVIEWS 244 


\begin{abstract}
The purpose of this study was to examine the relationship between job satisfaction and administrative support as perceived by secondary choral music educators in selected schools in the state of Texas. Further, the study ascertained whether or not perceived administrative support contributes to the teachers' decision to stay or leave the profession.
\end{abstract}

Subjects included early career teachers $(n=87)$ and their principals $(n=53)$ from five geographical regions in North Texas. Identical questionnaires were distributed to teachers and principals to ascertain their level of agreement regarding music education philosophy and the value of methods of professional assistance. In addition, teachers answered questions regarding job satisfaction, intention to stay or leave the teaching profession, and intention to stay or leave their current teaching position.

Results indicated that factors leading to greater job satisfaction include community and parent support, higher salary, and administrative support. Early career teachers intending to leave the profession included inadequate administrative support, lack of student motivation, job stress, and lack of student discipline among their primary reasons. Teachers intending to change schools indicated job stress, lack of student motivation, and lack of student discipline were primary factors. An examination of methods of professional assistance revealed that early career teachers rank colleagues in music field and music workshops and conferences as being the most beneficial.

A comparison of teachers' and their administrators' ratings of the value of various 
methods of assistance showed a non-significant positive correlation. In addition, a comparison of teachers' and their administrators’ philosophies of music education revealed a non-significant positive correlation. The low level of agreement between teachers and principals was consistent among teachers intending to leave the teaching profession, as well as those planning to change schools.

The study seemed to indicate that administrators do have an impact on job satisfaction, as well as the retention of early career teachers. A lack of agreement teachers and principals regarding philosophy of music education and the value of various methods of assistance seemed to be related to teachers' intention to both leave the teaching profession and to leave their current teaching position. 


\section{LIST OF TABLES}

4.1 Response rate of secondary choral directors by Region .................. 48

4.2 Response rate of early career teachers by Region ......................... 49

4.3 Response rate of principals of early career teachers by Region ............. 50

E.4 Early career teachers and principals by Region $\ldots \ldots \ldots \ldots \ldots \ldots \ldots \ldots \ldots \ldots \ldots \ldots$

4.5 Early career teachers and principals by District ...................... 51

4.6 Early career teachers and principals by School Type .................... 52

4.7 Early career teachers and principals by School Level .................... 53

4. 8 Early career teachers and principals by Conference ...................... 53

4. 9 Early career teachers and principals by Years of Teaching Experience

4.10 Early career teachers and principals by Years in Current

Teaching Position

4.11 Early career teachers and principals by Position on Choral

Staff

4.12 Early career teachers and principals by Number of People on

Choral Staff

4.13 Job satisfaction of early career teachers by Region .................... 57

4.14 Job satisfaction of early career teachers by District $\ldots \ldots \ldots \ldots \ldots \ldots \ldots \ldots \ldots . \quad 57$

4.15 Job satisfaction of early career teachers by School Type ................. 58

4.16 Job satisfaction of early career teachers by School Level ................. 58

4.17 Job satisfaction of early career teachers by Conference ................... 59

4.18 Job satisfaction of early career teachers by Years of Teaching

Experience 
4.19 Job satisfaction of early career teachers by Years in Current

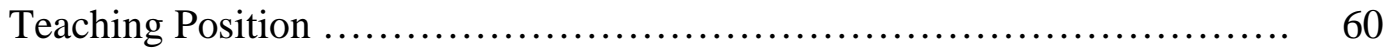

4.20 Job satisfaction of early career teachers by Position on

Choral Staff.

4. 21 Job satisfaction of early career teachers by Number of People

on Choral Staff

4.22 Frequency and percentage of factors increasing job satisfaction

in current teaching assignment of early career teachers

4.24 Frequency and percentage of factors increasing job satisfaction in current teaching assignment of early career teachers in Region 3

4.25 Frequency and percentage of factors increasing job satisfaction in current teaching assignment of early career teachers in Region 5

4.26 Frequency and percentage of factors increasing job satisfaction in current teaching assignment of early career teachers in Region 7

4.27 Frequency and percentage of factors increasing job satisfaction in current teaching assignment of early career teachers in Region 20

4.28 Frequency and percentage of factors increasing job satisfaction in current teaching assignment of early career teachers in Region 24

4.29 Frequency and percentage of factors increasing job satisfaction in current teaching assignment of early career teachers in District A

4.30 Frequency and percentage of factors increasing job satisfaction in current teaching assignment of early career teachers in District B

4.31 Frequency and percentage of factors increasing job satisfaction in current teaching assignment of early career teachers in District C

4.32 Frequency and percentage of factors increasing job satisfaction in current teaching assignment of early career teachers in District D

4.33 Frequency and percentage of factors increasing job satisfaction in current teaching assignment of early career teachers in District E - I

4.34 Frequency and percentage of factors increasing job satisfaction in current teaching assignment of early career teachers in rural schools 
4.35 Frequency and percentage of factors increasing job satisfaction in current teaching assignment of early career teachers in suburban schools

4.36 Frequency and percentage of factors increasing job satisfaction in current teaching assignment of early career teachers in urban schools

4.37 Frequency and percentage of factors increasing job satisfaction in current teaching assignment of early career teachers in high schools

4.38 Frequency and percentage of factors increasing job satisfaction in current teaching assignment of early career teachers in junior high schools

4.39 Frequency and percentage of factors increasing job satisfaction in current teaching assignment of early career teachers in middle schools

4.40 Frequency and percentage of factors increasing job satisfaction in current teaching assignment of early career teachers in Conference AA - AAAA schools

4.41 Frequency and percentage of factors increasing job satisfaction in current teaching assignment of early career teachers in Conference AAAAA schools

4.42 Frequency and percentage of factors increasing job satisfaction in current teaching assignment of early career teachers in Conference BB - BBB schools

4.43 Frequency and percentage of factors increasing job satisfaction in current teaching assignment of early career teachers in Conference CC schools

4.44 Frequency and percentage of factors increasing job satisfaction in current teaching assignment of early career teachers in Conference CCC schools

4.45 Frequency and percentage of factors increasing job satisfaction in current teaching assignment of early career teachers with 1 to 1.5 years of teaching experience

4.46 Frequency and percentage of factors increasing job satisfaction in current teaching assignment of early career teachers with 2 years of teaching experience 
4.47 Frequency and percentage of factors increasing job satisfaction in current teaching assignment of early career teachers with 3 to 3.5 years

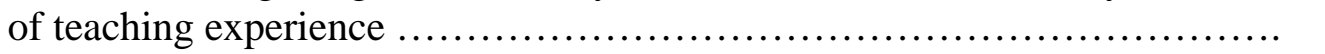

4.48 Frequency and percentage of factors increasing job satisfaction in current teaching assignment of early career teachers with 4 years of teaching experience

4.49 Frequency and percentage of factors increasing job satisfaction in current teaching assignment of early career teachers with 5 years of teaching experience

4.50 Frequency and percentage of factors increasing job satisfaction of early career teachers teaching in current school from 1 to 1.5 years

4.51 Frequency and percentage of factors increasing job satisfaction of early career teachers teaching in current school for 2 years

4.52 Frequency and percentage of factors increasing job satisfaction of early career teachers teaching in current school for 3 years

4.53 Frequency and percentage of factors increasing job satisfaction of early career teachers teaching in current school for 4 years

4.54 Frequency and percentage of factors increasing job satisfaction of early career teachers teaching in current school for 5 years

4.55 Frequency and percentage of factors increasing job satisfaction in current teaching assignment of early career teachers who are the head director

4.56 Frequency and percentage of factors increasing job satisfaction in current teaching assignment of early career teachers who are the assistant director

4.57 Frequency and percentage of factors increasing job satisfaction in current teaching assignment of early career teachers with 1 person on the choral staff

4.58 Frequency and percentage of factors increasing job satisfaction in current teaching assignment of early career teachers with 1.5 to 3 people on the choral staff 
4.59 Frequency and percentage of methods of professional assistance

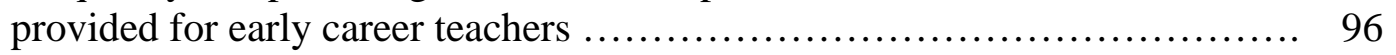

4.60 Methods of professional assistance provided for early career teachers in Region 3

4.61 Methods of professional assistance provided for early career teachers in Region 5

4.62 Methods of professional assistance provided for early career teachers in Region 7 100

4.63 Methods of professional assistance provided for early career teachers in Region 20 ...

4.64 Methods of professional assistance provided for early career teachers in Region 24 ..... 102

4.65 Methods of professional assistance provided for early career teachers in District A schools

4.66 Methods of professional assistance provided for early career teachers in District B schools

4.67 Methods of professional assistance provided for early career teachers in District C schools

4.68 Methods of professional assistance provided for early career teachers in District D schools

4.69 Methods of professional assistance provided for early career teachers in District E - I schools

4.70 Methods of professional assistance provided for early career teachers in rural schools

4.71 Methods of professional assistance provided for early career teachers in suburban schools

4.72 Methods of professional assistance provided for early career teachers in urban schools 
4.73 Methods of professional assistance provided for early career teachers in high schools

4.74 Methods of professional assistance provided for early career teachers in junior high schools

4.75 Methods of professional assistance provided for early career teachers in middle schools

4.76 Methods of professional assistance provided for early career teachers in Conference AA to AAAA schools

4.77 Methods of professional assistance provided for early career teachers in Conference AAAAA schools

4.78 Methods of professional assistance provided for early career teachers in Conference BB - BBB schools

4.79 Methods of professional assistance provided for early career teachers in Conference CC schools

4.80 Methods of professional assistance provided for early career teachers in Conference CCC schools

4.81 Methods of professional assistance provided for early career teachers with 1 to 1.5 years of teaching experience

4.82 Methods of professional assistance provided for early career teachers with 2 years of teaching experience

4.83 Methods of professional assistance provided for early career teachers with 3 to 3.5 years of teaching experience

4.84 Methods of professional assistance provided for early career teachers with 4 years of teaching experience

4.85 Methods of professional assistance provided for early career teachers with 5 years of teaching experience

4.86 Teachers' and principals' ratings of importance of methods of professional assistance to early career teachers 
4.87 Teachers' and principals' ratings of importance of methods of professional assistance to early career teachers in Region 3

4.88 Teachers' and principals' ratings of importance of methods of professional assistance to early career teachers in Region 5

4.89 Teachers' and principals' ratings of importance of methods of professional assistance to early career teachers in Region 7 ........................ 128

4.90 Teachers' and principals' ratings of importance of methods of professional assistance to early career teachers in Region 20

4.91 Teachers' and principals' ratings of importance of methods of professional assistance to early career teachers in Region 24

4.92 Correlation of mean teacher/principal responses to value of 19 methods of assistance by Region

4.93 Teachers' and principals' ratings of importance of methods of professional assistance to early career teachers in District A schools

4.94 Teachers' and principals' ratings of importance of methods of professional assistance to early career teachers in District B schools

4.95 Teachers' and principals' ratings of importance of methods of professional assistance to early career teachers in District C schools

4.96 Teachers' and principals' ratings of importance of methods of professional assistance to early career teachers in District D schools

4.97 Teachers' and principals' ratings of importance of methods of professional assistance to early career teachers in District E - I schools ....

4.98 Correlation of mean teacher/principal responses to value of 19 methods of assistance by District

4.99 Teachers' and principals' ratings of importance of methods of professional assistance to early career teachers in rural schools

4.100 Teachers' and principals' ratings of importance of methods of professional assistance to early career teachers in suburban schools

4.101 Teachers' and principals' ratings of importance of methods of professional assistance to early career teachers in urban schools

4.102 Correlation of mean teacher/principal responses to value of 19 methods of assistance by School Type 
4.103 Teachers' and principals' ratings of importance of methods of professional assistance to early career teachers in high schools

4.104 Teachers' and principals' ratings of importance of methods of professional assistance to early career teachers in junior high schools

4.105 Teachers' and principals' ratings of importance of methods of professional assistance to early career teachers in middle schools

4.106 Correlation of mean teacher/principal responses to value of 19 methods of assistance by School Level

4.107 Teachers' and principals' ratings of importance of methods of professional assistance to early career teachers in Conference AA to AAAA schools

4.108 Teachers' and principals' ratings of importance of methods of professional assistance to early career teachers in Conference AAAAA schools

4.109 Teachers' and principals' ratings of importance of methods of professional assistance to early career teachers in Conference BB to BBB schools

4.110 Teachers' and principals' ratings of importance of methods of professional assistance to early career teachers in Conference CC schools

4.111 Teachers' and principals' ratings of importance of methods of professional assistance to early career teachers in Conference CCC schools

4.112 Correlation of mean teacher/principal responses to value of 19 methods of assistance by Conference

4.113 Teachers' and principals’ ratings of importance of methods of professional assistance to early career teachers with 1 to 1.5 years of teaching experience

4.114 Teachers' and principals' ratings of importance of methods of professional assistance to early career teachers with 2 years of teaching

experience

4.115 Teachers' and principals' ratings of importance of methods of professional assistance to early career teachers with 3 years of teaching experience

4.116 Teachers' and principals' ratings of importance of methods of professional assistance to early career teachers with 4 years of teaching experience

4.117 Teachers' and principals' ratings of importance of methods of professional assistance to early career teachers with 5 years of teaching experience 
4.118 Correlation of mean teacher/principal responses to value of 19 methods of assistance by Years of Teaching Experience

4.119 Intention of early career teachers to either stay or leave the teaching profession by Region

4.120 Intention of early career teachers to either stay or leave the teaching profession by District

4.121 Intention of early career teachers to either stay or leave the teaching profession by School Type

4.122 Intention of early career teachers to either stay or leave the teaching profession by School Level

4.123 Intention of early career teachers to either stay or leave the teaching profession by Conference

4.124 Intention of early career teachers to either stay or leave the teaching profession by Years of Teaching Experience

4.125 Intention of early career teachers to either stay or leave the teaching profession by Years in Current Teaching Position

4.126 Intention of early career teachers to either stay or leave the teaching profession by Position on Choral Staff

4.127 Intention of early career teachers to either stay or leave the teaching profession by Number of People on Choral Staff

4.128 Frequency and percentage of early career teachers' reasons for intending to leave the teaching profession

4.129 Frequency and percentage of early career teachers intending to leave the teaching profession by Region

4.130 Frequency and percentage of early career teachers intending to leave the teaching profession by District 165

4.131 Frequency and percentage of early career teachers intending to leave the teaching profession by School Type

4.132 Frequency and percentage of early career teachers intending to leave the teaching profession by School Level 
4.133 Frequency and percentage of early career teachers intending to leave the teaching profession by Conference

4.134 Frequency and percentage of early career teachers intending to leave the teaching profession by Years of Teaching Experience.

4.135 Frequency and percentage of early career teachers intending to leave the teaching profession by Years in Current Teaching Position

4.136 Frequency and percentage of early career teachers intending to leave the teaching profession by Position on Choral Staff

4.137 Frequency and percentage of early career teachers intending to leave the teaching profession by Number of People on Choral Staff ....

4.138 Correlation of teacher/principal philosophy of music education among early career teachers intending to leave the teaching profession

4.139 Correlation of teacher/principal perception of professional assistance among early career teachers intending to leave the teaching profession

4.140 Frequency and percentage of early career teachers' reasons for intending to stay the teaching profession

4.141 Other reasons for staying in the teaching profession

4.142 Intention of early career teachers to either stay or leave their present teaching assignment by Region

4.143 Intention of early career teachers to either stay or leave their present teaching assignment by District 
4.144 Intention of early career teachers to either stay or leave their present teaching assignment by School Type

4.145 Intention of early career teachers to either stay or leave their present teaching assignment by School Level

4.146 Intention of early career teachers to either stay or leave their present teaching assignment by Conference

4.147 Intention of early career teachers to either stay or leave their present teaching assignment by Years of Teaching Experience

4.148 Intention of early career teachers to either stay or leave their present teaching assignment by Years in Current Teaching Position

4.149 Intention of early career teachers to either stay or leave their present teaching assignment by Position on Choral Staff

4.150 Intention of early career teachers to either stay or leave their present teaching assignment by Number of People on Choral Staff

4.151 Frequency and percentage of early career teachers' reasons for intending to change schools

4.152 Other reasons for early career teacher's intention to change schools

4.153 Early career teacher intention to change current teaching assignment by Region

4.154 Early career teacher intention to change current teaching assignment by District

4.155 Early career teacher intention to change current teaching assignment by School Type

4.156 Early career teacher intention to change current teaching assignment by School Level

4.157 Early career teacher intention to change current teaching assignment by Conference

4.158 Early career teacher intention to change current teaching assignment by Years of Teaching Experience

4.159 Early career teacher intention to change current teaching assignment by Years in Current Teaching Position

xviii 
4.160 Early career teacher intention to change current teaching assignment by Position on Choral Staff

4.161 Early career teacher intention to change current teaching assignment by Number of People on Choral Staff

4.162 Correlation of teacher/principal philosophy of music education of early career teachers intending to leave their current teaching position

4.163 Correlation of teacher/principal perception of professional assistance among early career teachers intending to leave their current teaching position

4.164 Demographic profile of interviewees

4.165 Teaching profile of interviewees

5.1 Rate of early career teacher intention to leave the teaching profession by Years of Teaching Experience

5.2 Subgroup correlation between early career teachers' and principals' ratings of methods of professional assistance and job satisfaction 


\section{CHAPTER I}

\section{ORIENTATION TO THE STUDY}

\section{Statement of the Problem}

Retention of qualified educators to fill teaching positions in our nation's schools is one of the most critical challenges facing the field of education today. The United States Department of Education estimates that as many as 2.7 million new teachers will be needed to staff public schools by 2009 (Henke, Choy, Geis \& Broughman, 1996).

The high rate of teacher attrition has substantially contributed to the teacher shortage (Ingersoll \& Smith, 2004). Hunt and Carroll (2002) point out that "the teacher 'shortage' turns out to be just the visible side of a coin, whose underside is high attrition rates" (p. 3). According to a survey conducted by Education Week (Merrow, 1999), about $20 \%$ of all beginning teachers quit teaching after 3 years, while $50 \%$ leave after 5 years. Ingersoll (2001) compares teacher turnover to a "revolving door" whereby teachers enter the field, then leave shortly thereafter in large numbers.

The alarming statistics on teacher shortages in the general education populace apply to the field of music education as well. The National Association for Music Education recently published a research report stating that approximately 11,000 new music teachers are needed to fill vacancies in the United States annually, yet only about 5, 500 new music educators join the profession each year (Hill, 2003).

One of the leading factors contributing to teacher attrition is lack of administrative support (Krueger, 2000; Natale, 1993). Research indicates that the reason new teachers 
are most likely to leave the profession is because they feel a lack of support during their early years in teaching, the most challenging in a teacher's career (Natale, 1993).

Studies demonstrate that job satisfaction among teachers is strongly contingent on positive administrative support (Heston, Dedrick, Raschke, and Whitehead, 1996). Beginning teachers who have a positive relationship with their principals are more likely to stay in the profession (Chapman \& Green, 1986; Colley, 2002; Fredricks, 2001; Ives, 2003; Jorissen, 2002; Peck, 2002; Westfall, 2003).

Because the quality of music programs may be considered to be contingent on the continuity of music personnel, music teacher attrition can diminish the effectiveness of music programs in the schools (Krueger, 2000). Thus, in order to improve the quality of music education in the United States, it is crucial that the shortage of music teachers be abated (Anderson, 2000). Retention of educators is a fundamental solution to alleviating the teacher shortage (Merrow, 1999). To ensure that beginning music teachers remain in the teaching profession, factors strongly affecting attrition need to be examined and evaluated (DeLorenzo, 1992; Madsen \& Hancock, 2002). Investigation into issues surrounding administrative support is particularly critical, in that a strong relationship appears to exist between teacher retention and support from administration (DeLorenzo, 1992).

\section{Purpose of the Study}

The purpose of this study is to examine the relationship between job satisfaction and administrative support and curricular philosophy as perceived by among secondary choral music educators in selected schools in the state of Texas. Further, the study will 
ascertain whether or not perceived administrative support and curricular philosophy contributes to the teachers' decision to stay or leave the profession. Finally, the study will determine whether or not perceived administrative support and curricular philosophy contributes to a teacher's decision to change schools.

\section{$\underline{\text { Research Questions }}$}

This study addresses the following questions: Is there a difference between the administrators' and teachers' perception of administrative support for beginning music teachers? Which issues are related to teacher job satisfaction? Which factors impact a teacher's decision to stay or leave the profession? Which factors affect a teacher's decision to stay or leave their current teaching assignment?

\section{Contribution and Significance of Study}

This study contributes to the body of research relating to beginning music teacher retention and attrition. As the review of literature will reveal, many studies have been conducted regarding why beginning teachers stay or leave the teaching profession. However, despite the fact that principals strongly influence teacher attrition and retention, there is a paucity of research regarding ways administrators can meets the needs of beginning teachers (Brock \& Grady, 1998). This holds true for beginning music teachers, as well. Conway (2003) states: "If music education researchers can create a solid research base dealing with beginning music teachers, we may be able to provide administrators and policy-makers with evidence of the needs of music teachers" (p. 21). 
The mass exodus of teachers early in the early phase of their careers and the burgeoning teacher shortage poses a problem for school administrators. Principals are in a position of authority whereby they can engage strategies to retain the teachers they hire. The findings of this study are intended to assist administrators in identifying variables influencing beginning choral music teachers' job satisfaction and their decision to stay or leave the teaching profession. Thus, providing principals a clearer understanding of pertinent factors can enable them to more successfully address the challenge of retaining beginning secondary choral music educators.

\section{Limitations of the Study}

This study contains several limitations. First, it is imperative to define attrition and retention as it will be used in this investigation. Billingsley (1993) points out that the research does not provide a decisive definition of the terms attrition and retention, thus their use is inconsistent. Grissmer and Kirby (1987) add that there is "no single appropriate definition of teacher attrition. Indeed, one cannot define teacher attrition until one defines the policy or research context in which a particular definition will be used" (p. 7).

This study only approximated teacher attrition or retention in that the new music teachers were questioned regarding their intention to continue teaching or to remain at the same school. Thus, for purposes of this study, attrition will include those teachers intending to leave the teaching profession or transferring to a different school. Retention pertains to new teachers intending to remain at the same school in the same teaching assignment. 
A second limitation to this study is that the data gathering instrument used is a questionnaire, which allows respondents to answer questions in ways they perceive to be favorable, rather than being truthful. Schloss and Smith (1999) explain:

Standardized questions can also be limiting. By trying to devise items that are minimally appropriate for a large number of people, you may miss what is important to some. In addition, responses can be artificial because, frankly, your respondents can lie. Surveys are self-reports of what people say they think or do. You have no way of knowing if the information they are providing is accurate; thus, the validity of your study may be undermined. (p. 57)

The element of anonymity is used in this study to encourage more truthful and accurate responses.

Finally, the subjects for this study consisted of 87 secondary choral teachers with four or fewer years of teaching experience at the beginning of the 2004-2005 school year. Subjects were selected from public schools in the North Texas area, including Regions 3, 5, 7, 20, and 24, as delineated by Texas Music Educators Association (TMEA).

Administrators used for this study consisted of 53 principals who were the immediate supervisors of beginning music teachers used in the study.

\section{$\underline{\text { Plan of Presentation }}$}

Chapter 2 includes a review of the pertinent literature related to teacher shortage, teacher attrition, administrative support, and job satisfaction.

Chapter 3 explicates the study design, including the development of the questionnaires, selection of subjects, implementation of data collection, and the statistical tests used. 
Chapter 4 contains the results of the study pertaining to the perception of administrative support and its relationship to job satisfaction and teacher attrition and retention.

Chapter 5 presents a discussion and explanation of the results. Recommendations for further research are included. 


\section{CHAPTER II}

\section{REVIEW OF THE LITERATURE}

\section{$\underline{\text { Shortage of Teachers }}$}

The growing shortage of teachers is an epidemic that plagues our nation's schools. Although the teaching profession has traditionally experienced high rates of turnover and attrition (Heyns, 1988), current trends potentially place our country's educational system in jeopardy. Studies indicate that more than two million teachers will be needed in the next ten years to staff our nation's schools. However, out of the approximately 200,000 new teachers that will be needed annually for the next ten years, estimates indicate that only about half that number will enter the teaching profession, and many of the new entrants will not stay. In addition, $25 \%$ of our nation's teachers are 50 years or older and are predicted to retire in the next ten years, creating additional positions that must be filled (Lucksinger, 2000).

A survey conducted by Scholastic Inc. and the Council of Chief State School Officers in 2000 revealed that nearly $50 \%$ of respondents reported a shortage of qualified teachers in their schools (Anderson, 2000). The American Institute for Employment in Education anticipates that the number of teachers needed in our nation's classroom will rise between 12 and $14 \%$ by the year 2008 (Anderson, 2000).

Texas Workforce Commission reports that Texas will need over 82,000 new teachers by 2008. The Bureau of Labor Statistics projects teaching as one of the fastest growing occupations over the next 5 to 10 years and beyond, with demand and growth continuing to increase (State Board for Educator Certification, 2004). 
The national teaching shortage is felt acutely in the field of music, with demand for music teachers at an all-time high, while the number of entrants is declining (Asmus, 1999). National statistics indicate that annually half as many music teachers as are needed graduate from colleges, with approximately half of those leaving the profession within their first years of service ("Teacher shortage"). The Montana Office of Public Instruction reported that music was the primary area of teaching shortage in the state for the 1999-2000 school year (Anderson, 2000).

As a result of the shortage of music teachers, many districts are forced to hire teachers who have do not have a degree in music education. In Florida, $12.1 \%$ of the new hires for music in 1999 were from "out of field," suggesting that there were an insufficient number of trained music educators to apply for the available jobs (Anderson, 2000). The Music Educators National Conference reports that between 9 and 27 million students in the United States do not receive a satisfactory music education due to a lack of trained music educators (Hill, 2003).

\section{$\underline{\text { Rate of Teacher Attrition }}$}

High rates of attrition are responsible for magnifying the teacher shortage. A study by the National Commission on Teaching and America's Future (Hunt \& Carroll, 2002) warns that "an alarming and unsustainable number of teachers" are leaving the profession during the first few years (p.3). Teaching has traditionally been characterized as a vocation with high levels of attrition, particularly among the beginners (Grissmer \& Kirby, 1987, 1997; Hunt \& Carroll, 2002; Lortie, 1975; Murnane, Singer, Willett, 
Kemple, \& Olsen, 1991; Veenman, 1984). Ingersoll (2002) notes that the attrition rate among teachers is significantly higher than for other vocations.

Research indicates that the highest rates of attrition occur during the early years of teaching (Curran, Abrahams, \& Manuel, 2000; Heyns, 1988; Ingersoll \& Smith, 2003; Keller, 2003; Merseth, 1992; Murnane, Singer \& Willett, 1988; Shenn, 1997b). Studies have found that $25 \%$ of teachers leave after one year (Norton, 1999) and $9.3 \%$ do not complete their first full year (Weiss \& Weiss, 1999). Additional studies show that as many as $40 \%$ of teachers will leave two years after entering the profession (Karge, 1993; Lucksinger, 2000; Sclan, 1993) and only 50\% remain in teaching after five years (Kestner, 19994; Norton, 1999). In 2002 , the Oregon Quality Assurance in Teaching Program (O-QAT) published a Teacher Attrition/Retention Study that revealed that onethird of Oregon's new teachers leave after only three years of teaching, which is in keeping with the national rate (Daly, 2002). A recent study reports that Texas has a $40 \%$ turnover rate among public school teachers in their first three years of teaching (Texas Center for Educational Research, 2000). Murnane, Singer, and Willett (1988) describe the likelihood of a beginning teacher surviving in the profession as follows:

At the very beginning of the study, when all the teachers have just started their employment, $100 \%$ of them are 'alive,' engaged in teaching, and their survival probability is 1 . As time passes, teachers gradually 'die,' leave the profession, and the survival probability drops steadily towards zero. (p. 25)

The first years of teaching have been described as a time of keen disillusionment (Gaede, 1978). Certo and Fox (2002) found that new teachers are largely unprepared for the demands of teaching. One teacher explains: 
[I] didn't realize that it would be like this...all the ways you are pulled by several different people, all the expectations, paperwork, after school, how to manage your time, how to organize it all when you feel like things are coming at you from all different directions. (p. 72)

As early as 1983 , Schlechty and Vance reported that $40 \%$ to $50 \%$ of teachers leave the profession within the first seven years. Many studies place the teacher attrition rate as high as $50 \%$ within the first 5 years (Chapman \& Hutcheson, 1982; Charters, 1970; Colbert \& Wolff, 1992; Colley, 2002; Huling-Austin, 1990; Ingersoll \& Smith, 2003; Mark \& Anderson, 1978; Murnane, Singer, Willett, Kemple, \& Olsen, 1991; Odell \& Ferrano, 1992). Beginning in the early 1990s, the number of teachers leaving has exceeded the number of entrants by an increasing rate (Darling-Hammond, 2003).

Attrition rates are even higher in high-poverty and urban schools (Delgado, 1999; Quartz, 2003). Ingersoll (2001) reports that teachers in high-poverty schools are 50\% more likely to leave than in low-poverty schools and that beginning teachers in urban districts leave at higher rates than their counterparts in suburban schools. Studies show that 30 to $50 \%$ of beginning teachers who teach in urban schools leave within the first three years (Hill, 2003).

A study by the National Commission on Teaching and America's Future (Hunt \& Carroll, 2002) indicates that while the teacher retention problem is found, in varying degrees, in every state, Texas was found to be one of the more dramatic cases. In 199899 school year, of the over 63,000 teaching positions opened in the state, about 46,600 , or $74 \%$ were due to teachers leaving the profession prior to retirement. Further, it was found that many of the teachers who left were new to the profession. Between 1993 and 1996 as many as 19\% of beginning teachers in Texas left teaching after their first year. 
Alternative certification, a provisional licensing arrangement whereby an applicant generally is required to have a bachelor's degree in the subject area taught and must take teacher preparation courses to meet state certification requirements, has been used by some districts to help alleviate the teaching shortages created by attrition (Anderson, 2000). However, a recent study in Texas which revealed that alternatively certified teachers had higher attrition rates than their certified counterparts (Fuller \& Alexander, 2003). Research indicates that the attrition rate for teachers who enter the profession through an alternative means can be as high as 60\% (Darling-Hammond, L., Berry, B., \& Thoreson, A., 2001). Moir (2003) explains that alternative certification contributes to the attrition rate, rather than diminishing teacher shortages. He states:

The loss of new teachers also has a follow-on effect, as replacement teachers are recruited in haste to meet class-size requirements. Often, these emergency hires lack adequate training. In some large urban cities, as many as 50\% of their new hires are on qualification waivers of some kind. Expected to complete their credentials even as they struggle to acquire real-life teaching experience, these replacement teachers' first years prove still more challenging, and the chances of them living up to their aspirations as educators are even lower. As each new generation of teachers face greater difficulties, the stage is set for a selfperpetuating cycle of attrition. Taxpayers, new teachers and, most importantly, students all bear the cost of this cycle. (p. 2)

Music education is also challenged by what Lautzenheiser (2001) describes as "the dual problem of a music teacher shortage and an alarming attrition rate" (p. 38). A survey of new members to the Texas Music Educators Association conducted by Killian and Baker (2004) found that $20 \%$ of music teachers intend to leave the profession regardless of years of experience, age, or teaching field. Madsen and Hancock (2002) conducted a longitudinal study of certified music teachers who graduated from the same university and found that $34.4 \%$ of them had left the teaching field after 6 years. 
Although numerous studies report music teacher shortages, a paucity of data is available regarding the attrition rate of music educators.

\section{$\underline{\text { Impact of Teacher Attrition }}$}

A low level of employee turnover is normal and healthy in any occupation in that it offsets potential stagnancy, eliminates low performers, and encourages innovation with the insertion of new blood (Ingersoll \& Smith, 2004). However, high levels of employee turnover lead to low performance and ineffectiveness in organizations, and result in a number of costs and negative consequences.

The expense of teacher turnover is far-reaching. A study by the National Commission on Teaching and America's Future (Hunt \& Carroll, 2002) reported that nationwide schools hired 534,861 teachers, but by the end of the school year, 539,778 had left their positions, resulting in a net loss of 4,917 teachers. Hunt and Carroll (2002) describe the result of the high turnover as follows:

This churning staff turnover keeps school administrators scrambling to find replacements, and in too many cases quality teaching is compromised in an effort to find a sufficient number of warm bodies to staff the classrooms. In the wake of this turmoil, student achievement declines. (p. 8)

Elevated rates of teacher attrition are costly in the recruitment, hiring, and training of new personnel. (Chapman, 1984; Brewster \& Railsback, 2001; Shen, 1997b). Norton (1999) explains that replacing employees costs $25 \%$ of each person's salary. Thus, if a school district loses $6 \%$ of 1,000 teachers earning $\$ 25,000$ annually, the replacement cost would be $\$ 375,000$. The price tag on the cost of replacing almost $16 \%$ of our nation's teachers annually is astronomical (Hunt \& Carroll, 2002). A study of Texas educators 
conducted in 2000 estimated that the annual turnover rate of $15 \%$, including a $40 \%$ attrition rate for teachers in their first three years, costs the state approximately $\$ 329$ million annually, or $\$ 8,000$ per recruit who leaves within the first few years. If the costs include termination, substitutes, learning curve loss, and new training, then the price could be as high as \$2.1 billion (Texas Center for Educational Research, 2000).

The high price tag of teacher turnover does not include the cost of what Kastelic calls "the loss of intellectual capital" (Ettorre, 1997, p. 4). Studies have found that teachers leaving the profession were more gifted academically and were more qualified than those who stayed (Chapman \& Green, 1986; Halford, 1998; Henke, Geis, \& Chen, 2000; Heyns, 1988; Murnane, Singer, Willett, Kemple, \& Olsen, 1991; Schlecty \& Vance, 1981). A study conducted by Davis (1988) found that $67.7 \%$ of the 108 teachers who had voluntarily withdrawn from teaching had average to superior performance ratings by their principals.

An additional consequence of high employee turnover is its negative effect on organizational coherence, stability, and morale. This is felt more acutely in education, in that extensive interaction is required between teachers, students, and families, thus making coherence, continuity, and cohesiveness critical (Ingersoll \& Smith, 2004). High teacher turnover has the potential to seriously undermine a positive sense of community among families, teachers, and students that has long been considered by education researchers to be one of the most important gauges and conditions of successful schools (Ingersoll, 2001). 
High rates of teacher attrition undermine both the quality and stability of school programs (Boe, Bobbitt, \& Cook, 1997; Lucksinger, 2000; Shen, 1997b). Millinger (2004) describes the negative outgrowth of teacher turnover as follows: "Principals find school culture difficult to establish, students consistently get inexperienced teachers, and the school community hesitates to make significant personal and financial investments in people who may not stay long enough to give something back" (p. 66).

The most severe consequence of high teacher turnover is its negative effect on teaching quality and student achievement. Evidence suggests that teacher ability is the single most important factor affecting student achievement (Curran, Abrahams, \& Manuel, 2000; Geringer, 2000). Research indicates that beginning teachers (those with fewer than two to three years of experience) are considerably less effective than more experienced teachers (Hunt \& Carroll, 2002). Evidence suggests that teacher effectiveness dramatically increases after the first few years of teaching (Kain \& Singleton, 1996); thus, schools fail to receive a long-term payoff from their investment in beginning teachers who leave (Carroll, Reichardt, \& Guarino, 2000; Darling-Hammond, 2003; Lucksinger, 2000). Berry (2004) points out:

With new teachers turning over at astronomical rates, school and district resources are withered away as more dollars have to be spent preparing a constant new crop of novices who arrive with little teaching knowledge and leave before they become skilled. (p. 22)

Attrition negatively affects the quality of music programs as well. When music teachers leave the profession and teaching positions go unfilled, music programs are cut from the curriculum (Bergee \& Demorest, 2003). Further, music programs are most 
effective when there is stability within the teaching staff and when that continuity is disrupted, student learning is hindered (Krueger, 2000; Shen, 1997b).

\section{Causes of Teacher Attrition}

A number of factors have been cited as causes of the high rate of teacher attrition, including student discipline problems (Eggen, 2002; Ingersoll, 1002; Langdon, 1996; Madsen \& Madsen, 1998; Norton, 1999; Norton \& Kelly, 1997; Veenman, 1984), salary (Colley, 2002; Ingersoll, 2001; Kim \& Loadman, 1994; Kirby \& Grissmer, 1993; Norton \& Kelly, 1997), and poor student motivation (Ingersoll, 2001; Ingersoll \& Smith, 2003; Jorissen, 2002). In addition, new teachers decide to leave the profession due to work environment issues, such as their assignment to the most difficult classes (Chapman \& Green, 1986; Colley, 2002; Halford, 1998; Norton, 1999; Ponessa, 1996), large numbers of students (Billingsley \& Cross, 1992; Eggen, 2002; Ingersoll, 2001; Norton, 1999; Norton \& Kelly, 1997), requirement to teach classes outside their teaching field (Johnson \& Birkeland, 2003a; Norton, 1999), the additional burden of extracurricular duties (Colley, 2002; Eggen, 2002; Norton, 1999; Norton \& Kelly, 1997; Ponessa, 1996), and a sense of isolation and abandonment (Chapman \& Green, 1986; Colley, 2002; Conway, 2003; Hope, 1999; Johnson \& Birkeland, 2003b; Jorissen, 2002; Krueger, 1999; Lortie, 1975; Lucksinger, 2000; Merrow, 1999; Norton, 1999).

Due to their lack of veteran status, most beginning teachers are assigned the remedial classes containing large numbers of low-achieving, unmotivated students with diverse needs (DePaul, 2000; Gordon, 1991; Halford, 1999; Huling-Austin, 1986; 
Kestner, 1994; Peck, 2002; Veenman, 1984; Yee, 1990). This is a major factor in their decision to defect from the teaching profession.

Education has been described as "the profession that eats its young" (Halford, 1998, p. 33). New teachers are held accountable for skills than can only be gained through experience (Huberman, 1989). Renard (2003) states: "we expect brand-new, just-out-of-the-wrapper teachers to assume the same responsibilities and duties as our most seasoned professionals, and we expect them to carry out those duties with the same level of expertise and within the same time constraints" (p. 63). Brewster and Railsback (2001) add that, unlike other fields in which new employees spend years training and preparing for challenging assignments, first-year teachers are oftentimes expected to carry out the same duties and responsibilities as veteran teachers who have taught for 20 years. Scott (1995) points out that it is no wonder that new teachers often feel "demoralized and dispirited, anxious about their efficacy and their capacity to cope" (p. 96).

Renard (2003) adds that veteran teachers can share stories about their first years when they received the worst students, the worst classrooms and supplies, the worst teaching assignments, had to teach from a cart with no classroom of their own, and were assigned unwanted duties, yet were expected to take it all in stride because they were expected to pay their dues. The culture of many high schools perpetuates the system whereby new teachers must survive overwhelming working conditions in order to "earn their stripes" (Peck, 2002). DePaul (2000) posits that vast numbers of promising teachers 
leave education due to lack of confidence, disillusionment, exhaustion, and lack of support.

Norton (1999) explains that new personnel are frequently given the heaviest teaching loads or are assigned to the most difficult schools in the district. He goes on to say that when first year teachers are placed in situations that provide them opportunities to capitalize on their strengths, to refer to their background and experiences, and to pursue their own interests, they are much more likely to be successful. Jorrisen (2002) points to appropriate teaching assignments as a major factor in teacher attrition: "Teaching subjects for which one is unprepared is a precursor to discouragement, disillusionment, dissatisfaction, and the abandonment of teaching" (p. 50).

A lack of input in decision-making regarding assessment, curriculum, policy and scheduling also results in teachers leaving the profession (Certo \& Fox, 2002). An additional factor leading to new personnel leaving the teaching profession is frustration and difficulties associated with administrative routines and the paperwork required (Eggen, 2002; Norton, 1999).

Music educators face challenges that are unique to their subject area, resulting in high levels of burnout and making them primary targets for attrition (Heston, Dedrick, Raschke, \& Whitehead, 1996). Madsen and Hancock (2002) explain that "although [general education] findings suggest relationships transferable to an investigation of music educators, the reinforcing nature of music, idiosyncratic teacher prerequisites, and unique demands placed on the in-service music teacher (e.g., performances) obfuscate generalization" (p. 8). 
Because music teaching frequently involves specialized skills and responsibilities that are not required of general educators, early career music teachers may require additional types of assistance (DeLorenzo, 1992). While both beginning music teachers and general classroom teachers encounter difficulties dealing with classroom management, assessment, curriculum, and a sense of isolation, the nature of the music classroom demands a unique approach to these challenges (Conway, Krueger, Robinson, Haack \& Smith, 2002). Conway, et al. (2002) explicate: "A novice often finds that strategies that work in a typical desk-lined classroom do not completely transfer to the challenges of a studio or rehearsal classroom" (p. 11). Whereas most regular classrooms contain a maximum of 30 students, secondary music classes can contain over 100 students. This large student population compounds the challenge of classroom discipline, planning curriculum, seating assignments, taking attendance, distribution of instructional and informative materials, and grading (Scheib, 2002).

Beginning secondary music teachers require assistance with the numerous administrative duties associated with their various ensembles. These duties include: (1) instrument assignment, purchasing, inventory, and maintenance; (2) uniform assignment, purchasing, alterations, and maintenance; (3) music inventory, selection, distribution, and arranging; (4) rehearsal scheduling; (5) performance scheduling; (6) transportation arrangements; (7) trip planning (e.g. schedule, lodging, chaperones, transportation, fundraising); and (8) booster club organization (Scheib, 2002).

Music educators are assigned numerous responsibilities beyond their teaching duties in order to manage and maintain a music program, including recruitment, planning 
concerts and trips, conducting rehearsals before and after school, fundraising, and pressures of public performances and competitions (Conway, 2003; Hamann, Daugherty \& Mills, 1987; Heston, Dedrick, Raschke \& Whitehead, 1996; Hylton, 1989; Scheib, 2002). Conway (2003) adds that secondary music teachers are required to take their ensembles to perform at football games, basketball games, graduation ceremonies, musicals, solo and ensemble festivals, tours, and many community events.

Jones (1978) points out that a whole spectrum of problems is faced by early career music teachers, including:

isolation, loneliness, culture-shock, in-service help, community relations, feelings of failure, of being in a 'sink-or-swim' situation, of feeling overworked, overburdened, overwhelmed, over-tired, of being confused by or in disagreement with administrative policies and evaluations, dealing with parents, and feeling threatened, insecure, or vulnerable. (p. 7)

Isolation during the first year of teaching is prevalent and often traumatic for beginning music teachers (Krueger, 2000; Thompson, 1988). A study conducted by Krueger (1999) found that a sense of isolation is a dominant pattern among beginning music teachers. Subjects reported that working an extended day, being the only music teacher in their school, traveling among several schools, and being removed from daily interaction with the other teachers in their schools contributed to their feelings of isolation. The subjects added that their sense of isolation was enhanced by the perception of classroom teachers that the music teacher's job was primarily to provide a planning period for the classroom teachers.

Factors leading to music teacher attrition include difficult teaching loads, inappropriate student behavior, and a perceived lack of support from school 
administrators and the community at large (Heston, Dedrick, and Raschke, 1996; Hoffer, 1982). Much of the research on beginning music teachers suggests that they are more frequently assigned to more difficult classes and more difficult teaching loads than the general educators (Conway, 2003; Gold, 1996; Odell \& Ferraro, 1992). A number of beginning teachers struggle with teaching assignments outside of their specialized content area (e.g., choir, orchestra, or band). Although some state certification programs include an all-encompassing music K-12, it does not necessarily follow that teachers are qualified to teach areas in music in which they have not had sufficient preparation or experience (Conway, 2003; Conway, 2002; Conway, 2001).

Additional factors leading to dissatisfaction among music teachers include inadequate music facilities and/or a deficient budget for equipment, supplies, and materials (Krueger, 2000). One teacher described her situation as follows:

The music facilities at our school were terrible; there was asbestos in the room, and it was so horrible that you knew the kids didn't feel good about it. They kept saying it was next on the list to be remodeled, but it had been for years. We could hear the band constantly since there was no soundproofing between rooms. Sometimes the rain on the metal room got so loud that we couldn't even sing. (Krueger, 2000, p. 24)

In a poll of music teachers who spent less than three years in the classroom, subjects disclosed the following reasons for leaving the profession: I had no idea I would spend so much time taking care of things outside of the music teaching. I didn't understand how to deal with budgets, schedules, other faculty members, administrators, and the ongoing responsibilities that just showed up every day. I found myself living in constant stress because I couldn't get everything accomplished. It was great working with the students making music, but that was such a small part of my day. There were so many things out of my control, and I didn't have anyone to turn to for help. (Lautzenheiser, 2001, p. 39) 


\section{$\underline{\text { Administrative Support }}$}

Studies indicate, additionally, that one of the leading causes of teacher attrition is lack of administrative support (Billingsley \& Cross, 1992; Certo \& Fox, 2002; Eggen, 2002; Hunt \& Carroll, 2002; Ingersoll, 1999; Ingersoll, 2001; Johnson \& Birkeland, 2003b; Krueger, 2000; Lucksinger, 2000; Marlow, Inman, Betancourt-Smith, 1997; Metzke, 1988; Natale, 1993; National Center for Educational Statistics, 1991; Norton, 1999; Norton \& Kelly, 1997; Ponessa, 1996; Ponick, Keating, Pontiff, \& Wilcox, 2003; Quartz, 2003; Whitener, Gruber, Lynch, Tingos, Perona, \& Fondelier, 1997).

Over $45 \%$ of the youngest public school teachers cited lack of administrative support as the primary reason why they left the teaching profession (Natale, 1993). Seventy-three percent of Oregon teachers named lack of administrative support as a factor influencing their decision to leave the profession during their first five years of teaching (Ankeny \& Zanville, 2002). In a study conducted by the National Education Association in 1990-91, teachers ranked "incompetent and uncooperative administrators" as the primary hindrance to doing their jobs well (Natale, 1993, p. 15). When asked what they found least satisfying about their job, teachers' number one response was lack of support from parents, administration, and community (Heston, Dedrick, Raschke, \& Whitehead, 1996). A study conducted by Ulriksen (1996) found that job dissatisfaction among teachers is most closely connected to administration and interpersonal relations.

A survey of 100 new teachers in a large metropolitan school district, revealed that $75 \%$ of the teachers received minimal help from principals and supervisors (Deal and Chatman, 1989). In a study conducted by the Teacher Standards and Practices 
Commission in Oregon (Myton,1984) it was found that school administrators reported providing more assistance than beginning teachers reported receiving. Administrative support was described as "ceremonial and ritualistic" and supervision was regarded as being "perfunctory and infrequent." Research indicates that principals have an inaccurate perception of the impact that they have upon teachers' job satisfaction (Ulriksen, 1996). Administrative support is defined by Certo and Fox (2002) as "policies or practices that support teacher work and create an environment that treats teachers as professionals" (p. 62). The principal is responsible for providing a nurturing work environment that encourages the retention of new teachers (Hipp \& Bredeson, 1995). Peck (2002) describes the administrator's role in teacher retention as follows: “The principal as the instructional leader of his or her school, has responsibility for hiring and retaining the best new teachers and is ultimately responsible for alleviating, and if possible, overcoming barriers that interfere with retention of new teachers" (p. 3).

A survey of 359 former South Carolina teachers indicated that the primary issue in teacher attrition is lack of support in areas over which administrators have some authority, including behavior management support, supportive environment, workload/work role support, and financial support (Eggen, 2002). National survey data show that teachers' decisions to remain in teaching are closely associated with the teachers' perceptions about administrative support, resources, and teacher input in policy and decision making in their schools (Darling-Hammond, 1997).

Administrative support encompasses a large domain, including: new teacher assignment practices; visibility/spending time in classrooms; listening to teachers' needs 
and positions; professional development practices; resources and supplies; and teacher recognition (Certo \& Fox, 2002). Beginning teachers look to their principals to provide instructional leadership and support, thus providing "opportunities to experiment, refine their craft, and mature" (Colley, 2002). In a study conducted by Brock and Grady (1998) first-year teachers named the school principal a primary source of guidance and support. However, new teachers pointed out that principals often overlook two important issues: the need for assistance throughout the first year and the vital role the principal performs in the new teacher induction process.

The quality of the first teaching experience is the factor that is most closely connected with attrition (Ankeny \& Zanville, 2002; Chapman, 1984; Hope, 1999; Karge, 1993). Chapman (1984) points out that administrators can influence attrition by "shaping the tone and quality of a new teacher's first teaching experience" (p. 655). The first year of teaching is critical in that it strongly influences what kind of teacher a person will become (Hope, 1999).

Working conditions are largely viewed as the most critical factor in high rates of teacher attrition (Heyns, 1988; Hunt \& Carroll, 2002; Lucksinger, 2000). School administrators are primarily responsible for setting the tone for the school's working environment (Fredricks, 2001). Administrative support plays a key role in either positively or negatively impacting the working conditions of a new teacher (Peck, 2002). Billingsley (1993) posits: “Administrators influence the conditions in which teachers work; therefore, it is not surprising that administrative support has been consistently linked to attrition or retention" (p. 153). 
The working conditions that teachers face upon their entrance into the teaching profession strongly influences their decision to either leave or stay (Peck, 2002). New teachers' comfort levels and their desire to stay in teaching are in direct relationship with their perception of administrative, collegial and parental support (Ankeny \& Zanville, 2002; Karge, 1993). In the Eggen (2002) study, beginning teachers who left the profession described administrators as "not caring, avoiding visibility in the school, staying out of classrooms, and giving little feedback to new teachers" (p. 2). In a study 50 new teachers in Massachusetts, the leavers described principals as being "arbitrary, abusive, and neglectful," as well as "absent, punitive, and controlling” (Johnson \& Birkeland, 2003a, p. 594, 599).

Research shows that retention of new teachers is strongly affected by work conditions over which administrators wield control, such as resources for teaching, professional development, spending time in the classroom (visibility), listening to teachers' needs, and input in decision making (Certo \& Fox, 2002; Chapman \& Green, 1986; Colley, 2002; Daly, 2002; Darling-Hammond, 2003; Karge, 1993; Shen, 1997b; Wells, 1993).

The classroom of a new entrant into teaching often becomes an "isolation chamber" in which they must either "sink or swim" (Ingersoll, 2003; Johnson, 1990; Johnson \& Birkeland, 2003a). Principals can address this sense of isolation by visiting new teachers' classrooms regularly and providing constructive feedback (Hope, 1999). Colley (2002) explains that “it is when the principal's support and affirmation is absent 
that beginners feel abandoned and that they lack the resources to succeed" (p. 22). Gold

(1996) maintains:

From the perceptions of new teachers, the beginning months of teaching are crucial in their decision to make a commitment to teaching and to remain in the profession. One of their major goals for this first state of teaching is to be in an assignment that is congruent with how they perceive themselves and the teaching role. If the situation is too challenging, they feel overwhelmed. If it is too lacking in opportunities for growth and development, they tend to be disappointed and discouraged. The context, therefore, into which the new teacher is placed is of utmost importance for the new teacher's success. (p. 578)

Beginning teachers oftentimes receive teaching assignments that diminish

their chances of success (Lucksinger, 2000). As one teacher explained:

Administrators give new teachers the hardest, most challenging classes and the most preparations, so they have maybe four different classes to prepare for every day, and then administrators expect that that's going to make them excited about teaching. It's just not conducive to retaining young, enthusiastic people.

(Morrow, 2000, p. 51)

Ingersoll and Smith (2003) state that four school working conditions

predominantly influence a teacher's decision to quit: lack of support from school

administration; classroom management; lack of student motivation; and no influence over classroom and school wide decision making. Administrators can play a vital role in solving school staffing problems by “improving teachers' working conditions [which] would contribute to lower rates of new teacher turnover, thereby diminishing school staffing problems and improving the performance of schools" (Ingersoll \& Smith, 2003, p. 33).

Conversely, administrators strongly influence a teacher's decision to remain in the profession (Betancourt-Smith, Inman, \& Marlow, 1994; Billingsley, 1993; Bobbitt, Faupel, \& Burns, 1991; Brewster \& Railsback, 2001; Chitton \& Sistrunk, 1990; Ingeroll, 
1999; Johnson \& Birkeland, 2003a; Metzke, 1988; Peck, 2002). In a study investigating teacher retention and attrition in Virginia schools, Certo and Fox (2002) discovered that quality administration was one of the primary reasons teachers remain in the profession. Certo and Fox (2002) found that "reasons for leaving and reasons for staying often acted as inverse variables (for example, a teacher may leave because of poor administration or stay because of quality administration)" (p. 60). The results of a study conducted by Ingersoll (2001) indicate that turnover rates are decidedly lower in schools that provide greater administrative support to teachers. Wong (2004) describes effective administrators as those who provide support to new teachers by believing in their potential to become effective educators, collaborating with them, teaching them, and being an effective role model.

Certo and Fox (2002) explain:

Principals play a crucial part in administrative support by supporting and encouraging teachers. When principals communicate their expectations clearly, enforce student rules of conduct consistently, and support teachers in doing so, provide professional development or resources when necessary, and when teachers are evaluated fairly and recognized for their strengths and accomplishments, teachers are more inclined to have high morale and to be committed to their teaching positions. (p. 72)

Fredricks (2001) adds:

The most important thing an administrator can do is support the teachers. Teachers who know they have the backing of their administrators will feel the freedom to experiment with new teaching techniques and find the best way to help their students succeed. (p. 48)

Shen (1997a) noted that a statistical difference exists between teachers remaining in the profession and those leaving in terms of their perception of their working 
conditions. Stayers tend to perceive that administrators are more aware of their problems and that they have more input in the formulation of school- and teaching-related policies (Shen, 1997b). Research indicates that teacher retention is linked to working conditions which include a supportive principal who provides opportunities for teacher leadership, teacher input in decision making, time to observe colleagues, and a smaller workload (Berry, 2004).

Lucksinger (2000) reports that having a supportive work environment appears to be more influential in retaining new teachers than salaries. She compares teaching to business and industry, where $70 \%$ of employees quit their jobs because they are dissatisfied with their immediate supervisor. Jorrisen (2002) states: "Principals who keep good teachers are those who provide an environment in which new teachers develop competence, gain a sense of efficacy, and take pride in being teachers. These are the teachers who stay" (p. 54).

With appropriate administrative support, "new teachers ought to emerge from their first few years of teaching feeling empowered, supported, and capable in all roles of the classroom teacher" (Renard, 2003, p. 64). Colley (2002) summarizes the influence of administrators on teacher attrition as follows:

Given the projections for teacher shortages in the next decade, the principal's role as a supporter and nurturer of new teachers becomes increasingly significant. By providing instructional leadership, cultivating a positive culture, and fostering mentor relationships, principals create conditions that will provide their schools with a staff of stable, competent, and successful teachers. (p. 24)

Hope (1999) suggests a number of ways in which administrators can retain teachers, including: (1) a positive orientation and induction process, (2) intervention to 
diminish teacher isolation, (3) facilitation of mentoring and collegial relationships, (4) maximizing potential for success through appropriate teaching assignments, (5) providing development opportunities, and (6) offering development opportunities.

Jorissen (2002) lists 10 ways in which a principal can help new teachers stay in the profession: (1) hire teachers whose profile indicates they are likely to stay; (2) assign new teachers to positions in which they are licensed and have previous experience; (3) limit extra duties, preparations, and traveling; (4) develop a system of collaborative problem solving; (5) assign an experienced teacher mentor; (6) depend on mentors to help novice teachers deal with the culture shock of the first year; (7) establish and maintain a positive personal relationship with the new teacher; (8) involve new teachers in decision making; (9) facilitate professional integration during the first three years; and (10) recognize teacher accomplishments.

A study conducted by Brewster and Railsback (2001) listed the following methods administrators can provide support for new teachers: (1) make the development of a formal program of new teacher support a priority; (2) fund programs for new teachers; (3) do not assign beginning teachers to the most challenging classes; (4) assign teachers to the same subject area and grade level in which they did their student teaching, if possible; (5) conduct orientations designed for new teachers at the beginning of the school year; (6) provide teachers with student background information before school begins; (7) give new teachers the teaching materials they need; (8) clearly outline expectations for new teachers; (9) make beginning teachers aware that you support their success; (10) meet with novice teachers on a weekly basis; (11) include beginning 
teachers in the larger school community; (12) provide and support professional development activities for new teachers.

Based on the data from his study, Ingersoll (2001) offers the following:

Improvements in organizational conditions, such as increased salaries, increased support from the school administration, reduction of student discipline problems, and enhanced faculty input into school decision-making, would all contribute to lower rates of turnover, thus diminish school staffing problems, and ultimately aid the performance of schools. (p. 24)

Sclan (1993) summarizes the way supportive and collaborative school environments influence teacher retention as follows:

Feeling involved in important decision making, working cooperatively, and setting school discipline policy crucially shape beginning teachers' perceptions of school leadership and culture, which, in turn, predicts beginning teacher's work commitment, career choice commitment, and planned retention. (p. 153)

Lack of administrative support strongly impacts music teacher attrition.

Beginning music teachers described administrative support issues as including "differing understandings of the importance of music education, a perception of music as an extracurricular activity, challenges to the content of instruction, apathy for music education, music valued solely for utilitarian purposes, and music classes used as a respite for 'academic' teachers" (Madsen \& Hancock, 2002, p. 15). Additionally, secondary music teachers experience conflict in that the community largely discounts the value of music education and places them "more in the business of entertainment than education" (Hoffer, 1982, p. 60).

In a 1984 study conducted by Hamann and Daugherty, music educators indicated that the primary frustration of their job included lack of recognition by administration, and unclear goals from principals and music administration. In a similar study conducted 
by Stubblefield (1984) “...interviews of 24 randomly selected music teachers indicated that little or no support from school system, lack of administrative staff support, lack of budget, and pay incentive were major sources of stress" (p. 50). Krueger (1999) points out that many music educators feel that music is "marginalized or misunderstood within the school curriculum by being labeled as a 'special' subject" (p. 9).

In a study conducted by Krueger (2002) early career music teachers cited insufficient administrative support as a primary problem. Subjects viewed relations between administrators and teachers as greatly affecting teacher autonomy and morale in the school. Further, the subjects held administrators accountable for shaping the support and attitude towards music of other members of the school faculty. As one teacher noted:

My principal could have been much more supportive; music was always treated as an extra-curricular activity in our school, not central to the curriculum. I always felt on the outside with the other teachers; they would want to pull students out of music as if it wasn't important, and the principal allowed it. They didn't seem to realize that we have a sequential curriculum, too; they just saw music as a singalong hour. (p. 23)

\section{$\underline{\text { Job Satisfaction }}$}

Job dissatisfaction plays a major role in beginning teacher attrition (Ingersoll \& Smith, 2003). A study by Hall, Pearson \& Carroll (1992) showed that teachers who were leaving the profession reported lower levels of job satisfaction and more negative attitudes toward school administrators and teaching as a career. Dinham (1994) points out that job dissatisfaction is largely related to administrative issues, such as lack of resources, large class sizes, and educational procedure and policies. Krueger (2000) adds that teachers cited inadequate administrative support, lack of support network, demanding 
teaching positions, job insecurity, and insufficient funding for resources and facilities as factors influencing their dissatisfaction with teaching.

Studies indicate that the key factor in the assessment of teacher job satisfaction is workplace conditions (Haycock, 1998, 2000; Hoy \& Miskel, 1991; Johnson \& Birkeland, 2003a; National Center for Educational Statistics, 1997; Norton, 1999; Peck, 2002;

Taylor \& Tashakkori, 1994). Johnson \& Birkeland (2003a) explain:

A good workplace can reduce... uncertainty and increase a teacher's chances for success and satisfaction; by contrast, a deficient workplace is likely to increase uncertainty and fuel a teacher's dissatisfaction. The working conditions that matter to teachers encompass a wide range of factors, from school facilities and bureaucracy to the competence of administrators and opportunities for professional development. A heavy teaching load, an unsupportive principal, or a broken copy machine can interfere with good teaching and make it hard for teachers to achieve the intrinsic rewards they seek. (p. 584)

Working conditions that new teachers face upon entering the teaching profession strongly influence both job satisfaction and teacher retention (Byrne, 1992; Veenman, 1984). Little (1996) sets forth the following working condition issues that can either enhance or diminish a teacher's job satisfaction: appropriate teaching assignments; sufficient time allotted to work with students and colleagues; professional development; access to materials, information, and technology; and useful feedback on teaching.

Norton (1999) explicates that the more favorable the work conditions, "such as administrative leadership and support, school climate, teacher autonomy in the classroom, student behavior, and parental support," the higher the job satisfaction. In reference to Holland's theory of vocational choice (1973), Chapman and Hutcheson (1982) posit: "People search for environments that will let them exercise their skills and abilities, express their attitudes and values, and take on agreeable problems and roles" 
(p. 94). A study conducted by Shann (1998) revealed that teacher satisfaction is affected by participation in decision making.

Literature supports that job satisfaction is closely connected to the quality of the interpersonal relationships between administrators and teachers (Bogler, 1999; Chapman, 1983, 1984; Chapman \& Hutcheson, 1982; Hipp \& Bredeson, 1995; Peck, 2002; Rinehart, Short, Short, \& Eckley, 1988). Bogler (2001) states: “Overall, teachers report greater satisfaction in their work when they perceive their principal as someone who shares information with others, delegates authority, and keeps open channels of communication with the teachers" (p. 666). Research indicates that a teacher's job satisfaction is strongly impacted by an administrator's recognition and approval (Chapman \& Lowther, 1982).

Studies reveal that teacher job satisfaction is closely related to teacher retention (Betancourt-Smith, Inman, \& Marlow, 1994; Billingsley, 1993; Borg \& Riding, 1991; Chittom \& Sistrunk, 1990; Millinger, 2004; Shann, 1998; Shin \& Reyes, 1995). Further, research indicates job satisfaction is affected by strong administrative leadership and support (Anderman, Belzer, \& Smith, 1991; Betancourt-Smith, Inman, \& Marlow, 1994; Billingsley, 1993; Chitton \& Sistrunk, 1990; Firestone, Rosenblum \& Webb, 1987; Heston, Dedrick, \& Raschke, 1996; Hoffer, 1982). Bogler (2001) maintains that teachers experience greater job satisfaction when working with a principal who exhibits a transformational leadership style by showing personal attention to the interests and needs of the teachers. He states, "To improve the general feeling of all teachers, school 
principals need to be more aware of how strongly their role and behavior affect teachers' perceptions about their occupation—and their job satisfaction" (p. 679).

This holds true among music educators, as well. In a study conducted by Heston, Dedrick, Raschke, and Whitehead (1996), music teachers listed positive administrative support as one of the aspects of their job that they found most satisfying. DeLorenzo (1992) found that beginning music teachers wanted administrators who were supportive, accessible, and encouraging. As one respondent stated, you should "have an open invitation to sit down and discuss problems without feeling you are taking valuable time from them or that you are chasing them down for answers" (p. 21).

Studies indicate that administrators can have a profound effect on music teacher job satisfaction. A number of factors contribute to job dissatisfaction among music educators, including discipline problems, student apathy, conflicts with school administrators and other teachers, inadequate facilities and equipment, concert performances, and insufficient time to complete assigned duties (Mercer \& Mercer, 1986). Similar results were found in a study of 101 music educators conducted by Hamann, Daughtery, \& Mills (1987) which revealed that job dissatisfaction was a consequence of music teachers feeling overwhelmed by their work load and the time allotted to complete their work, lack of cooperation from other teachers, and unclear directives and goals from administrators. Scheib (2003) reports that job dissatisfaction among school music teachers is a result of feeling undervalued due to a perceived lack of administrative support and insufficient resources to accomplish the overwhelming amount of work required. 
A study of public school band directors (Heston, Dedrick, Raschke, \& Whitehead, 1996) found that the areas of teaching that they found the least satisfying in order of response frequency were: (1) lack of support from administration, parents, and community, (2) workload, (3) lack of student commitment, and (4) nonteaching duties or busywork. This same study revealed that the most satisfying aspects of the band directors' jobs in order of response frequency included: (1) working with students, (2) support from administration, parents, and colleagues, (3) having involvement with music, and (4) seeing music programs develop and be successful. 


\section{CHAPTER III}

\section{DESIGN AND METHODOLOGY OF THE STUDY}

This chapter includes the following major topics: (1) the research questions; (b) the design of the study; (3) construction of the questionnaires; (4) sampling procedures; (5) administration of the survey; and (6) procedures for data analysis.

\section{$\underline{\text { Research Questions }}$}

The first research question examines any differences between the administrators' and teachers' perceptions of administrative support for beginning music teachers. For purposes of this study, administrative support includes both principals' and teachers' views of the importance and position of music education in the schools, as well as specific types of available support. Methods of administrative support include: in service programs, new teacher orientation programs, fine arts supervisor, other music and non-music teachers in school, colleagues in music field, assigned mentor teacher (music and non-music), music workshops or conferences, release time to observe experienced music teachers, accessibility of administrator, administrator's visits to class room, administrative assistance with classroom management, administrative assistance with budget preparation, assistance with administrative duties, administrative assistance with large classes, release time to work with feeder school choirs, release time for performances outside of school, and release time for recruiting students from other schools. 
The second research question investigates which factors are related to teacher job satisfaction. These factors include administrative support, support from faculty members and parents, salary, job assignment, school environment, job autonomy, recognition, educational preparation, and other.

The third research question addresses issues that might impact a teacher's decision to stay or leave the profession. Issues addressed include: administrative support; community support; job autonomy; work environment; teaching assignment; student motivation and discipline; career change; staff reduction; salary; and personal issues.

The fourth research question examines factors that might affect a teacher's decision to stay or leave their current teaching position. Issues addressed include: administrative support; parent and community support; job autonomy; work environment; teaching assignment; student motivation and discipline; salary; staff reduction; and personal issues.

\section{Design of the Study}

The design of the study utilized both quantitative and qualitative research strategies to address the research questions. Quantitative data were collected from teachers and administrators via researcher-designed questionnaires. Qualitative data were collected via interviews with selected subjects.

\section{Questionnaire Components}

Teachers were given the Questionnaire (See Appendix A) which consisted of 4 parts: 1) Music Education Questionnaire, 2) Professional Assistance for Music Teachers, 
3) Job Satisfaction, and 4) Survey of Early Career Music Teachers. Administrators completed the first two parts of the questionnaire: 1) Music Education Questionnaire and 2) Professional Assistance for Music Teachers.

Measurement for the first part, Music Education Questionnaire, was based on a five-point scale of ordinal, closed-response categories. Subjects were asked to choose from the following categories:

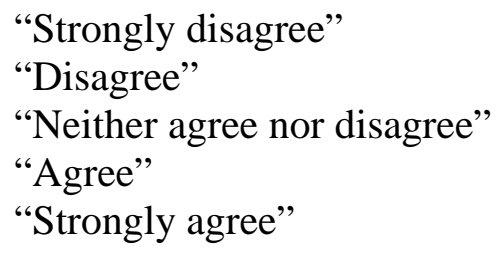

Subsequently the texts were given numbers for analysis purposes.

The second part, Professional Assistance for Music Teachers, utilized a six-point, ordinal, closed response scale. Administrators and early career teachers were asked to rate methods of professional assistance based on the following categories:

$\begin{array}{ll}\text { "N/A" } & (0) \\ \text { "No help" } & (1) \\ \text { "Little help" } & (2) \\ \text { "Moderately helpful" } & (3) \\ \text { "Very helpful" } & (4) \\ \text { "Extremely helpful" } & (5)\end{array}$

Additionally, teachers were given a list of methods of professional assistance and were asked to indicate which methods were provided in their school.

Part 3, Job Satisfaction, provided the following scale for teachers to rank job satisfaction:

"Very dissatisfied"

"Some dissatisfied"

"Neither dissatisfied nor satisfied" 
"Somewhat satisfied"

"Very satisfied"

In addition, subjects were asked to select factors that would increase their job satisfaction from the list given.

The fourth part, Survey of Early Career Music Teachers, measured teachers' intentions to either stay or leave the teaching profession with the following categories:

"Definitely plan to leave after this year"

"Likely to leave after this year"

"Undecided"

"Likely to stay after this year"

"Definitely plan to stay after this year"

Teachers planning to leave the profession were asked to select the reasons affecting their decision from the list provided. Teachers planning to stay in the teaching profession were asked to select the factors affecting their decision from the list provided.

An additional question, addressed to teachers who indicated that they planned to continue to teach, measured teachers' intentions to either stay or leave their present teaching assignment. The categories provided included:

"Definitely plan to change schools after this year"

"Likely to change schools after this year"

"Undecided"

"Likely to stay at this school after this year"

"Definitely plan to stay at this school after this year"

Teachers were provided a checklist and were asked to select the reasons affecting their decision to either stay or leave their present teaching assignment.

In the qualitative portion of the study, subjects selected for interviews were representative of various demographics and degrees of job satisfaction and perception of administrative support. Interviews were conducted in person and were recorded. 
Questions focused on early career teacher's perception of community/parent support, administrative support, support of other faculty members, school environment and the primary factors that impacted the teacher's decision to either stay in teaching or to leave the profession. Procedures for interviews were in accordance with criteria provided by Merriam (1998) in Qualitative Research and Case Study Applications in Education.

\section{Questionnaire Construction}

The content of the first part of the questionnaire, Music Education Questionnaire, was based on informal interviews of both experienced and inexperienced music educators. The experienced music educators $(n=24)$ had from 6 to 30 years of teaching experience in choral music. The inexperienced music educators $(n=15)$ had from one month to 5 years of teaching experience. They were asked to respond to the question: What are some of the areas of music education in which you and your administrator have philosophical differences? Their responses were recorded and served as the basis for the questionnaire. The researcher reworded the responses into statements and then conducted a pilot study of the Music Education Questionnaire, using secondary school administrators $(\mathrm{n}=5)$, and music educators $(\mathrm{n}=7)$. Revision of the wording of the statements was based upon their recommendations.

The design and content of the second section of the questionnaire, Professional Assistance for Music Teachers, was largely based a study of beginning music teachers conducted by DeLorenzo (1992). Included in the questionnaire were the following methods of professional assistance for first-year teachers which were used in DeLorenzo's study: 
In-service programs

New teacher orientation program

Fine arts supervisor

Other teachers in the school

Building principal(s)

Colleagues in the field

Assigned mentor teacher

In addition, secondary school administrators $(n=5)$ were asked to respond to the question: What are some of the methods of professional assistance that are provided for new teachers in your school? The administrators' responses included: accessibility of administrator, administrators' visits to classroom, administrative assistance with classroom management, and administrative assistance with large classes.

Finally, secondary choral educators $(n=7)$ were asked to respond to the question: What are some of the methods of assistance that your administrator provides you in your school? Teachers' responses included the following: music workshops or conferences, release time to observe experienced music teachers, administrative assistance with budget preparation, assistance with administrative duties (fundraising, trips, competitions), release time to work with feeder school choirs, release time for performances outside of school, and release time for recruiting students from other schools.

The following methods of professional assistance were included in part 2, Professional Assistance for Music Teachers:
a. In-service programs
b. New teacher orientation program
c. Fine arts supervisor
d. Other music teacher in school
e. Other non-music teachers in school
f. Colleagues in music field
g. Assigned mentor teacher (non-music)
h. Assigned mentor teacher (music) 
i. Music workshops or conferences

j. Release time to observe experienced music teachers

k. Accessibility of administrator

1. Administrators' visits to classroom

$\mathrm{m}$. Administrative assistance with classroom management

$\mathrm{n}$. Administrative assistance with budget preparation

o. Assistance with administrative duties (fundraising, trips, competitions)

p. Administrative assistance with large classes

q. Release time to work with feeder school choirs

r. Release time for performances outside of school

The third part of the questionnaire, Job Satisfaction, was developed by extracting factors cited by previous studies presented in Chapter 2. The question posed was: Which of the following (if any) would increase your job satisfaction in your current teaching assignment? The factors listed in the questionnaire were:

a. Administrative support

b. Support of other faculty members

c. Community/parent support

d. Higher salary

e. Fewer classes

f. Smaller classes

g. Improved school environment

h. Support with discipline problems

i. Participation in decision making

j. Recognition of accomplishments

k. Adequate educational preparation for this teaching assignment

1. Other (please specify)

The content of the fourth part, Survey of Early Career Music Teachers, was derived from a study of music teachers new to the profession administered by Killian and Baker (2004). The first question posed was: Within the next year, how likely is it that you will stay in the teaching profession OR leave the teaching profession to go into some different occupation? Teachers indicating their intention to leave were asked the following question: What is the primary reason affecting your decision to leave the 
teaching profession? The following reasons, extracted from the Killian and Baker study, were listed:
a. Inadequate administrative support
b. Lack of influence over school policies
c. Lack of parental/community support
d. Lack of adequate preparation time
e. Poor opportunities for advancement
f. Lack of student motivation
g. Lack of student discipline
h. Pursue other music career
i. Attend graduate school in music
j. Pursue career outside of music
k. Elimination of program
1. Reduction in staff
m. Low salary
n. Isolation
o. Multi-campus duties
p. Workload issues
q. Scheduling issues
r. Classes too large
s. Unsafe environment
t. Pregnancy/child care
u. Moving
v. Health
w. Job stress
x. Other (please specify)

Teachers indicating their intention to stay in the teaching profession were asked the following question: What are the reasons affecting your decision to stay in the teaching profession? The following reasons, obtained from the study by Killian and Baker (2004), were listed:
a. Administrative support
b. Influence over school policies
c. Parental/community support
d. Adequate preparation time
e. Opportunities for advancement
f. Student motivation
g. Student discipline 

h. Salary
i. Workload
j. Schedule
k. Class size
1. Environment
m. Support of other teachers
n. Other (please specify)

In addition, the teachers were asked: If you plan to stay in the teaching profession, how likely is it that you will leave your school to teach somewhere else within the next year? Teachers who indicated that they planned to leave their schools were asked: If you plan to leave your school, what is the primary reason affecting your decision to change schools? Choices for response included:
a. Inadequate administrative support
b. Lack of influence over school policies
c. Lack of parental/community support
d. Lack of adequate preparation time
e. Poor opportunities for advancement
f. Lack of student motivation
g. Lack of student discipline
h. Elimination of program
i. Reduction in staff
j. Low salary
k. Job stress
1. Isolation
m. Multi-campus duties
n. Workload issues
o. Scheduling issues
p. Classes too large
q. Unsafe environment
r. Moving
s. Pregnancy/Children
t. Other (please specify) 


\section{$\underline{\text { Pilot Study of the Instrument }}$}

All aspects of the study, both quantitative and qualitative, first underwent a pilot study with administrators $(n=5)$, beginning music teachers $(n=8)$, and experienced music teachers $(n=7)$. The purpose of the pilot test was twofold: first, to solicit feedback from the respondents in an effort to improve the clarity of the questionnaire and second, to serve as a measure for validity and reliability. Based on the administrators' and teachers' responses, minor revisions were made to the instrument.

\section{$\underline{\text { Selection of Subjects }}$}

The State of Texas is divided into 24 regions, as delineated by Texas Music Educators Association. This study focused on five of the Regions: 3, 5, 7, 20, and 24, which are located in the North Texas area in close proximity to the researcher and include rural, suburban, and urban schools. Contact information for the secondary choral directors was obtained from each Region's website. In addition, each Region secretary was contacted for updated contact information regarding teachers new to their Region. Initially, all of the secondary choral directors $(n=440)$ were asked to respond to the following question: Including the current school year, how many total years of teaching experience do you have?

Teachers who indicated that they had five years or less of teaching experience $(\mathrm{n}=104)$ were then sent the Early Career Secondary Choral Music Teacher Survey (See Appendix B). Questions included: school name, address, phone, and e-mail information; school district; conference (school size as determined by population); principal's name; number of years of teaching experience; number of people on choral staff at their school; 
and position (head or assistant). At the bottom of the questionnaire, respondents were asked the following questions: Would you be willing to participate in a research project by completing a brief questionnaire? and Would you be willing to participate in an individual interview regarding your teaching experience?

Of the 96 teachers who returned the questionnaire, everyone indicated a willingness to participate in the study except one. Demographic data from the questionnaire was used to develop two information sheets: Early Career Music Teacher Contact Information and Early Career Music Teacher School Information.

Included in the demographic data was a designated Conference based on the teacher's school's population and in accordance with the guidelines set forth by the University Interscholastic League (See Appendix C). High schools (grades 9 - 12) were assigned a letter designation of either A, AA, AAA, AAAA, or AAAAA, depending on the student population of the individual campus. Junior high schools (grades 7 - 9) were categorized as either $\mathrm{B}, \mathrm{BB}$, or $\mathrm{BBB}$ and middle schools (grades $7-8$ ) were categorized as either $\mathrm{C}, \mathrm{CC}$, or CCC. A single letter designated a smaller student population, with each subsequent letter representing a larger population.

The school district of each teacher was assigned a letter, based on the District Size tables utilized by the Texas Education Agency in the Snapshot 2002 report, the latest complete report available (See Appendix D). Districts were grouped by size into nine categories contingent on the number of students in each district. Category A districts were the largest, with a student population of 50,000 and over, whereas Category I districts we re the smallest, with a population under 500. 
Thus, respondents were categorized by geographical location (Region 3, 5, 7, 20, and 24), size of school district (District A, B, C, D, and E - I), and size of individual school population (Conference AA-AAAA, AAAAA, BB - BBB, CC, and CCC).

\section{Administration of the Survey}

The questionnaire, along with a cover letter (See Appendix E), was e-mailed to the early career music teachers $(n=95)$ in the beginning of November, 2004. Parts 1 and 2 of the questionnaire and a cover letter (See Appendix F) were e-mailed to the principals in the middle of November, 2004. The timing of this schedule allowed for teachers and administrators to experience almost a complete semester before responding and permitted a sufficient amount of time for additional mailing before the end of the semester. At the beginning of December, a questionnaire, cover letter, and a self-addressed envelope were mailed to the school of the teachers and principals who had failed to respond.

\section{$\underline{\text { Data Analysis }}$}

The Music Education Questionnaire, the first part of the questionnaire, required that teachers and principals use a 5-point Likert scale to indicate their level of agreement or disagreement with statements regarding priorities in music education. The Spearman rank correlation procedure was used to compare the music teacher's and respective administrator's responses. Professional Assistance for Music Teachers, the second part of the questionnaire, directed teachers and principals to rate the value of various methods of professional assistance using a 5-point Likert scale. Responses of the music teachers and their respective principal were compared using Spearman rank correlation. 
Mean and standard deviation were calculated for teachers' and principals' rating of the value of various methods of professional assistance and teachers' rating of job satisfaction, intention to stay or leave the teaching profession, and intention to stay or leave current teaching position. Calculations included the total group of teachers and total group of principals, as well as subgroups of teachers as differentiated by relevant variables such as Region, District, School Type, School Level, Conference, Years of Teaching Experience, Years in Current Teaching Position, Position of Choral Staff, and Number of People on Choral Staff.

The factors increasing job satisfaction in current teaching assignment, methods of professional assistance provided, early career teachers' reasons for intending to leave the teaching profession, and early career teachers' reasons for leaving their current job assignment were tabulated in terms of frequencies and percentages of total teachers responding.

In addition to the quantitative data, qualitative data were collected through the use of interviews. The content of the interviews was based on the findings of the quantitative data. Thus, selected text from the interviews illustrated and substantiated the findings, as recommended in Collecting and Interpreting Qualitative Materials (Denzin \& Lincoln, 1998, p. 8). Excerpts from the transcriptions of the interviews were used to explicate the quantitative data. Generally, the excerpts were quoted verbatim. However, any reference or information that could result in the identification of the individual was omitted to ensure total anonymity of the respondents. 


\section{CHAPTER IV}

\section{RESULTS}

Data consisted of questionnaire responses from 87 teachers and 53 principals. For the purpose of analysis, respondents were placed in the following subgroups: Region (based on geographic location), District (based on size of school district), School Type (rural, suburban, urban), School Level (high school, junior high school, middle school), Conference (based on size of individual school), Years of Teaching Experience, Years in Current Teaching Position, Position on Choral Staff (head or assistant), and Number of People on Choral Staff.

\section{$\underline{\text { Subject Response Rate }}$}

Contact of potential subjects for the study was facilitated by accessing the web site of each of the 5 Regions, in addition to contacting the Region Chairs for information regarding new members. Out of a total of 440 secondary choral directors, as listed on applicable website, 331 responded, resulting in a response rate of 75.2\% (See Table 4.1).

Table 4.1: Response rate of secondary choral directors by Region

\begin{tabular}{cccccc}
\hline Region & $\begin{array}{c}5 \text { years or } \\
\text { less of } \\
\text { teaching } \\
\text { experience }\end{array}$ & $\begin{array}{c}\text { Over 5 years } \\
\text { of teaching } \\
\text { experience }\end{array}$ & $\begin{array}{c}\text { No } \\
\text { response }\end{array}$ & $\begin{array}{c}\text { Total of } \\
\text { secondary } \\
\text { choral } \\
\text { directors }\end{array}$ & $\begin{array}{c}\text { Total } \\
\text { response } \\
\text { rate }\end{array}$ \\
\hline 3 & 23 & 49 & 18 & 90 & $79.9 \%$ \\
5 & 34 & 51 & 36 & 121 & $70.2 \%$
\end{tabular}


Table 4.1: Continued

\begin{tabular}{cccccc}
\hline Region & $\begin{array}{c}5 \text { years or } \\
\text { less of } \\
\text { teaching } \\
\text { experience }\end{array}$ & $\begin{array}{c}\text { Over 5 years } \\
\text { of teaching } \\
\text { experience }\end{array}$ & $\begin{array}{c}\text { No } \\
\text { response }\end{array}$ & $\begin{array}{c}\text { Total of } \\
\text { secondary } \\
\text { choral } \\
\text { directors }\end{array}$ & $\begin{array}{c}\text { Total } \\
\text { response } \\
\text { rate }\end{array}$ \\
\hline 7 & 7 & 31 & 15 & 53 & $71.6 \%$ \\
20 & 18 & 36 & 30 & 84 & $64.2 \%$ \\
Total & 104 & 60 & 10 & 92 & $89.1 \%$ \\
\hline
\end{tabular}

Ninety-six of the 104 secondary choral directors with 5 years or less of teaching experience completed the demographic survey. A total of 87 out of the 96 early career teachers who responded to the demographic survey (90.6\%) completed the questionnaire used to collect data for the study (See Table 4.2).

Table 4.2: Response rate of early career teachers by Region

\begin{tabular}{ccccc}
\hline Region & $\begin{array}{c}5 \text { years } \\
\text { or less of } \\
\text { teaching } \\
\text { experience }\end{array}$ & $\begin{array}{c}\text { Response } \\
\text { to } \\
\text { questionnaire }\end{array}$ & $\begin{array}{c}\text { No } \\
\text { response }\end{array}$ & $\begin{array}{c}\text { Total } \\
\text { response } \\
\text { rate }\end{array}$ \\
\hline 3 & 20 & 20 & 0 & $100.0 \%$ \\
5 & 31 & 27 & 3 & $87.0 \%$ \\
7 & 6 & 6 & 0 & $100.0 \%$ \\
20 & 17 & 13 & 4 & $76.4 \%$ \\
24 & 22 & 87 & 1 & $95.4 \%$ \\
Total & 96 & 8 & $90.6 \%$ \\
\hline
\end{tabular}


Out of the 87 teachers who completed the questionnaire, 53 of their principals returned the principal portion of the questionnaire, resulting in a principal response rate of $60.9 \%$ (See Table 4.3$)$.

Table 4.3: Response rate of principals of early career teachers by Region

\begin{tabular}{ccccc}
\hline Region & $\begin{array}{c}\text { Total } \\
\text { principals }\end{array}$ & $\begin{array}{c}\text { Response } \\
\text { to } \\
\text { questionnaire }\end{array}$ & $\begin{array}{c}\text { No } \\
\text { response }\end{array}$ & $\begin{array}{c}\text { Total } \\
\text { response } \\
\text { rate }\end{array}$ \\
\hline 3 & 20 & 15 & 5 & $75.0 \%$ \\
5 & 27 & 14 & 13 & $51.8 \%$ \\
7 & 6 & 3 & 3 & $50.0 \%$ \\
20 & 13 & 7 & 6 & $53.8 \%$ \\
Total & 87 & 14 & 7 & $66.6 \%$ \\
\hline
\end{tabular}

\section{Demographic Findings}

A total of 87 early career teachers completed the study's questionnaire. Subjects were subdivided into Regions, which are geographic areas assigned to schools by Texas Music Educators Association for the purpose of competitions (See Table 4.4). Region 5 had the largest number of respondents, 27 (31.0\% of the total respondents) and Region 7 had the fewest, $6(6.8 \%)$. The distribution of the responses from the various Regions was in keeping with the total number of secondary choral directors in the respective Regions, i. e., Region 5 has 117 choir directors, whereas Region 7 has 52. 
Table 4.4: Early career teachers and principals by Region

\begin{tabular}{ccc}
\hline Region & Teachers & Principals \\
\hline 3 & 20 & 15 \\
5 & 27 & 14 \\
7 & 6 & 3 \\
20 & 13 & 7 \\
24 & 21 & 14 \\
\hline
\end{tabular}

In accordance with the student population of their school district, subjects were assigned to a District, as outlined by the Texas Education Agency (See Table 4.5). District designations ranged from District A, which were the most populous districts (50,000 students and over), to District I, the smallest districts (under 500 students).

Teachers from Districts A, B, and C, the most populous districts, comprised $80 \%$ of the total respondents. The remaining $20 \%$ of respondents were from Districts D, E, F, G, and I, the least populous districts.

Table 4.5: Early career teachers and principals by District

\begin{tabular}{lcc}
\hline District Size & Teachers & Principals \\
\hline A $(50,000+)$ & 24 & 13 \\
B $(25,000$ to 49,999$)$ & 21 & 12 \\
C $(10,000$ to 24,999$)$ & 25 & 17 \\
D $(5,000$ to 9,999$)$ & 10 & 7
\end{tabular}


Table 4.5: Continued

\begin{tabular}{lcc}
\hline District Size & Teachers & Principals \\
\hline E $(3,000$ to 4,999$)$ & 4 & 3 \\
F $(1,600$ to 2,999$)$ & 1 & 0 \\
G $(1,000$ to 1,599$)$ & 0 & 0 \\
H $(500$ to 999$)$ & 2 & 1 \\
I (Under 500) & 0 & 0 \\
\hline
\end{tabular}

School type—rural, suburban, or urban—was teacher-identified on the questionnaire (See Table 4.6 ). Fifty-seven subjects (65.5\%) reported that they taught in suburban schools, $25(28.7 \%)$ in urban schools and only $5(5.7 \%)$ in rural areas. Urban teachers were underrepresented in this study, given the large number of urban schools in Regions 5 and 20. The number of suburban and rural teachers more closely represented their respective school type.

Table 4.6: Early career teachers and principals by School Type

\begin{tabular}{ccc}
\hline School Type & Teachers & Principals \\
Rural & 5 & 3 \\
Suburban & 57 & 34 \\
Urban & 25 & 16 \\
\hline
\end{tabular}


Almost half of the subjects, 42 (48.2\%), taught in middle school, while 26 (29.8\%) taught in high school and $19(21.8 \%)$ in junior high school (See Table 4.7).

Table 4.7: Early career teachers and principals by School Level

\begin{tabular}{lcc}
\hline Level & Teachers & Principals \\
\hline High School & 26 & 18 \\
Junior High & 19 & 8 \\
Middle School & 42 & 27 \\
\hline
\end{tabular}

Subjects were assigned to Conferences, a designation made by the State of Texas University Interscholastic League, based on school level and population (See Table 4.8). The majority of the respondents taught at the largest schools within their respective Conference level, with 13 out of 26 high school teachers at Conference AAAAA schools, 5 out of 6 teachers in Grade 7 through 9 schools at BBB junior high schools, and 29 out of 55 teachers at Grade 6 through 8 schools at CCC middle schools.

Table 4.8: Early career teachers and principals by Conference

\begin{tabular}{lcc}
\hline Conference & Teachers & Principals \\
\hline A $(189$ and below $)$ & 0 & 0 \\
AA $(190-389)$ & 2 & 1 \\
AAA $(390-899)$ & 0 & 0 \\
AAAA $(900-1924)$ & 11 & 7 \\
AAAAA $(1925$ and above $)$ & 13 & 11
\end{tabular}


Table 4.8: Continued

\begin{tabular}{lcc}
\hline Conference & Teachers & Principals \\
\hline B $(0-249)$ & 0 & 0 \\
BB $(250-649)$ & 1 & 0 \\
BBB $(650$ and above $)$ & 5 & 3 \\
C $(0-249)$ & 0 & 0 \\
CC $(250-649)$ & 26 & 16 \\
CCC $(650$ and above $)$ & 29 & 15 \\
\hline
\end{tabular}

The respondents were fairly evenly divided in terms of years of teaching experience (See Table 4.9). Sixteen teachers (18.3\%) had 1 to 1.5 years experience, 18 teachers $(20.6 \%)$ had 2 years experience, 20 teachers $(22.9 \%)$ had 3 to 3.5 years experience, and 20 teachers $(22.9 \%)$ had 5 years experience. However, only 13 teachers $(14.9 \%)$ with 4 years experience responded to the questionnaire.

Table 4.9: Early career teachers and principals by Years of Teaching Experience

\begin{tabular}{lcc}
\hline Years of Teaching & Teachers & Principals \\
\hline $1-1.5$ & 16 & 10 \\
2 & 18 & 10 \\
$3-3.5$ & 20 & 11 \\
4 & 13 & 7 \\
5 & 20 & 15 \\
\hline
\end{tabular}


As the number of years the subjects had held their current teaching position increased, the number of subjects decreased (See Table 4.10). Thirty-four subjects had taught 1 to 1.5 years in their current school, 22 had taught 2 years, 20 had taught 3 years, 6 had taught for 4 years, and 5 had taught for 5 years. A total of $39 \%$ of the subjects were in their first year at their current school, yet only $18 \%$ of them were first-year teachers. The numbers seem to indicate that teachers tend to change schools during their first 5 years of teaching.

Table 4.10: Early career teachers and principals by Years in Current Teaching Position

\begin{tabular}{lcc}
\hline Years & Teachers & Principals \\
\hline $1-1.5$ & 34 & 19 \\
2 & 22 & 14 \\
3 & 20 & 14 \\
4 & 6 & 3 \\
5 & 5 & 3 \\
\hline
\end{tabular}

Fifty-eight of the respondents were the head director at their school, whereas the remaining 29 were assistants (See Table 4.11). This is partially a result of the fact that a majority of the respondents were the only person on the choral staff at their school. 
Table 4.11: Early career teachers and principals by Position on Choral Staff

\begin{tabular}{ccc}
\hline Choral Staff Position & Teachers & Principals \\
\hline Head & 58 & 30 \\
Assistant & 29 & 23 \\
\hline
\end{tabular}

However, in terms of the number of teachers on the choral staff at the respondents' schools, 46 indicated there was only one person on staff, while 41 reported that their choral staff ranged from 1.5 to 3 in number (See Table 4.12).

Table 4.12: Early career teachers and principals by Number of People on Choral Staff

\begin{tabular}{ccc} 
Number of People & Teachers & Principals \\
\hline 1 & 46 & 22 \\
1.5 & 2 & 1 \\
2 & 36 & 27 \\
3 & 3 & 3 \\
\hline
\end{tabular}

\section{Teacher Job Satisfaction}

Early career teachers were asked to rate their job satisfaction using a 5-point Likert scale, ranging from 1 (Very dissatisfied) to 5 (Very Satisfied). The mean scores suggested that early career secondary choral directors were relatively satisfied with their current teaching position $(\mathrm{Mean}=4.1 ; \mathrm{SD}=.91)$ 
The Regions with the highest reported job satisfaction were Region 3 and Region 24. Region 20 had the lowest level of job satisfaction (See Table 4.13).

Table 4.13: Job satisfaction rating of early career teachers by Region

\begin{tabular}{cccc}
\hline Region & $\mathrm{n}$ & Mean & SD \\
\hline 3 & 20 & 4.2 & .95 \\
5 & 27 & 4.1 & .62 \\
7 & 6 & 4.0 & .63 \\
20 & 13 & 3.8 & 1.2 \\
24 & 21 & 4.2 & 1.0 \\
\hline
\end{tabular}

Job satisfaction varied in terms of district size with District B schools having the highest level of job satisfaction and District D schools having the lowest level (See Table 4.14).

Table 4.14: Job satisfaction rating of early career teachers by District

\begin{tabular}{lccc} 
District & $\mathrm{n}$ & Mean & SD \\
\hline A & 24 & 4.2 & .93 \\
B & 21 & 4.4 & .67 \\
C & 25 & 4.0 & .81 \\
D & 10 & 3.7 & 1.4 \\
E $-\mathrm{I}$ & 7 & 4.1 & .69 \\
\hline
\end{tabular}


The location of the schools also had a bearing on job satisfaction, with teachers in suburban schools reporting the highest amount of satisfaction. Subjects in rural schools and urban schools reported lower levels of job satisfaction (See Table 4.15).

Table 4.15: Job satisfaction rating of early career teachers by School Type

\begin{tabular}{lccr}
\hline Type & $\mathrm{n}$ & Mean & SD \\
\hline Rural & 5 & 3.8 & .83 \\
Suburban & 57 & 4.2 & .79 \\
Urban & 25 & 3.9 & 1.1 \\
\hline
\end{tabular}

Consistent ratings of job satisfaction were found among teachers in each of the three levels of schools_-high schools, junior high schools, and middle schools (See Table 4.16).

Table 4.16: Job satisfaction rating of early career teachers by School Level

\begin{tabular}{lccr} 
Level & $\mathrm{n}$ & Mean & SD \\
\hline High School & 26 & 4.2 & .86 \\
Junior High & 19 & 4.0 & .62 \\
Middle School & 42 & 4.1 & 1.0 \\
\hline
\end{tabular}

In terms of job satisfaction by Conference, the data indicated that Conference AAAAA had the highest level and Conference AA - AAAA and Conference CCC had the lowest levels (See Table 4.17). 
Table 4.17: Job satisfaction rating of early career teachers by Conference

\begin{tabular}{lccr}
\hline Conference & $\mathrm{n}$ & Mean & SD \\
\hline AA - AAAA & 13 & 4.0 & 1.1 \\
AAAAA & 13 & 4.3 & .50 \\
BB - BBB & 6 & 4.1 & .40 \\
CC & 26 & 4.1 & .95 \\
CCC & 29 & 4.0 & 1.0 \\
\hline
\end{tabular}

Respondents with 3 to 3.5 years and 5 years of teaching experience expressed the greatest job satisfaction. Respondents with 4 years of teaching experience reported the lowest job satisfaction of any subgroup in the study (See Table 4.18).

Table 4.18: Job satisfaction rating of early career teachers by Years of Teaching Experience

\begin{tabular}{lccc}
\hline Years & $\mathrm{n}$ & Mean & SD \\
\hline $1-1.5$ & 16 & 4.0 & 1.1 \\
2 & 18 & 4.0 & .99 \\
$3-3.5$ & 20 & 4.3 & .58 \\
4 & 13 & 3.6 & .85 \\
5 & 20 & 4.3 & .93 \\
\hline
\end{tabular}

Teachers who had taught in their present school for 1 to 1.5 years, 2 years, 3 years, and 4 years all indicated high levels of job satisfaction. Teachers who had been 
employed at the same school for 5 years reported the highest job satisfaction of any subgroup in the study (See Table 4.19).

Table 4.19: Job satisfaction rating of early career teachers by Years in Current Teaching Position

\begin{tabular}{lccc}
\hline Years & $\mathrm{n}$ & Mean & SD \\
\hline $1-1.5$ & 34 & 4.0 & .90 \\
2 & 22 & 4.0 & 1.1 \\
3 & 20 & 4.2 & .69 \\
4 & 6 & 4.1 & 1.1 \\
5 & 5 & 4.6 & .54 \\
\hline
\end{tabular}

Analysis of Position on Choral Staff indicated that assistant directors reported slightly greater job satisfaction than head directors (See Table 4.20).

Table 4.20: Job satisfaction rating of early career secondary choral directors by Position on Choral Staff

\begin{tabular}{lccc} 
Position & $\mathrm{n}$ & Mean & SD \\
\hline Head & 58 & 4.0 & .94 \\
Assistant & 29 & 4.2 & .87 \\
\hline
\end{tabular}

Teachers who worked on a choral staff with 1.5 to 3 people reported higher job satisfaction than those who were the sole member of the choral staff (See Table 4.21). 
Table 4.21: Job satisfaction rating of early career teachers by Number of People on Choral Staff

\begin{tabular}{lccc} 
People on Staff & $\mathrm{n}$ & Mean & SD \\
\hline 1 & 46 & 4.0 & 1.0 \\
$1.5-3$ & 41 & 4.3 & .78 \\
\hline
\end{tabular}

In section 3 of the questionnaire, Job Satisfaction, respondents were provided with a checklist of 12 factors that might increase their job satisfaction in their current teaching assignment. Issues concerning support appeared to be predominant among the factors selected by the respondents (See Table 4.22). Teacher responses indicated that the primary factor that would increase their job satisfaction was community/parent support (60.9\%). Higher salary was the second most popular response at 58.6\%. Other factors regarding support followed, with administrative support at $41.3 \%$ and support of other faculty members at $39.0 \%$. In addition, support with discipline problems was cited by $37.9 \%$.

Other factors teachers indicated that would lead to greater job satisfaction included improved school environment (34.4\%), recognition of accomplishments (32.1\%), and participation in decision making (28.7\%). The items least selected were adequate educational preparation for this teaching assignment (12.6\%), fewer classes (11.4\%), and smaller classes $(11.4 \%)$. 
Table 4.22: Frequency and percentage of factors increasing job satisfaction in current teaching assignment of early career teachers $(n=87)$

Factor

Frequency

Percentage

Community/parent support

53

60.9

Higher salary

58.6

Administrative support

Support of other faculty members

39.0

Support with discipline problems

Improved school environment

Recognition of accomplishments

Other

Participation in decision making

Adequate educational preparation

for this teaching assignment

Fewer classes

Smaller classes

10

11.4

Included in the list of factors that might increase job satisfaction was Other, whereby teachers could add a factor that was not included in the questionnaire. Twentyseven respondents $(31.0 \%)$ listed Other factors that would increase their job satisfaction. Some of the 27 respondents listed multiple comments, resulting in a total of 44 comments (See Table 4.23). Following procedures used by DeLorenzo (1992), job satisfaction issues named by subjects were divided into 5 categories: job specific concerns, support, 
autonomy, training, and feeder schools. A complete list of Other comments is found in Appendix G.

Table 4.23: Other factors leading to greater job satisfaction among early career teachers

Factor Frequency

Job Specific Concerns

Bigger budget 2

Not being the assistant 2

Assigned to 1 campus, not 2

Better facilities 1

Work fewer hours outside of school $\quad 1$

Less paperwork 1

More computer accessibility 1

Limited duty assignments $\quad 1$

Team conference time 1

Full-time position, rather than part-time 1

Better working relationship with head director $\quad 1$

Total 14

Support

Parents teaching children how to be respectful 3

More interested/motivated students 2

Teacher encouragement 1

Higher school morale 1

Improved benefits 1

Better informed administration regarding music education and competitions $\quad 1$

$\begin{array}{lr}\text { Total } & 9\end{array}$ 
Table 4.23: Continued

Factor

Frequency

\section{Autonomy}

Student placement in choir classes

4

Scheduling

2

Ownership over program

1

Students not removed from choir class to

work on core subjects

1

Total

8

Training

Budget preparation 3

Fundraising 2

$\begin{array}{ll}\text { Teaching experience } & 1\end{array}$

Teaching at-risk students 1

Classroom management 1

Total 8

Feeder Schools

Release time for recruitment 3

Students better trained 1

Restructure 1

Total 5

Checklist factors leading to greater job satisfaction were also examined by subgroups, beginning with Regions (See Tables 4.24 - 4.28). 
Table 4.24: Frequency and percentage of factors increasing job satisfaction in current teaching assignment of early career teachers in Region $3(n=20)$

Factor

Frequency

Percentage

Community/parent support

11

55.0

Improved school environment

9

45.0

Higher salary

8

40.0

Support of other faculty members

5

25.0

Support with discipline problems

5

25.0

Recognition of accomplishments

5

25.0

Administrative support

4

20.0

Participation in decision making

4

20.0

Fewer classes

4

20.0

Other

Smaller classes

2

10.0

Adequate educational preparation for this teaching assignment 1

Table 4.25: Frequency and percentage of factors increasing job satisfaction in current teaching assignment of early career teachers in Region $5(n=27)$

Factor

Frequency

Percentage

Community/parent support

16

59.2

Higher salary

16

59.2 
Table 4.25: Continued

Factor

Frequency

Percentage

Support with discipline problems

12

Administrative support

12

11

11

9

7

5

Participation in decision making

Adequate educational preparation

for this teaching assignment

3

1

Fewer classes

Smaller classes
44.4

3.7

12

44.4

40.7

40.7

33.3

25.9

18.5

11.1

3.7

Table 4.26: Frequency and percentage of factors increasing job satisfaction in current teaching assignment of early career teachers in Region $7(n=6)$

Factor

Frequency

Percentage

Community/parent support

5

83.3

Higher salary

5

83.3

Administrative support

3

50.0

Other

50.0

Support with discipline problems 
Table 4.26: Continued

Factor

Frequency

Percentage

Participation in decision making

2

33.3

Support of other faculty members

1

16.6

Improved school environment

1

16.6

Recognition of accomplishments

1

16.6

Adequate educational preparation

0

0.0

for this teaching assignment

Fewer classes

0

0.0

Smaller classes

0

0.0

Table 4.27: Frequency and percentage of factors increasing job satisfaction in current teaching assignment of early career teachers in Region $20(n=13)$

Factor

Frequency

Percentage

Community/parent support

10

76.9

Administrative support

9

69.2

Support with discipline problems

8

61.5

Participation in decision making

7

53.8

Improved school environment

53.8

Higher salary

6

46.1

Other

6

46.1

Support of other faculty members

4

30.7 
Table 4.27: Continued

Factor

Frequency

Percentage

Smaller classes

4

30.7

Recognition of accomplishments

4

30.7

Adequate educational preparation

for this teaching assignment

3

23.0

Fewer classes

2

15.3

Table 4:28: Frequency and percentage of factors increasing job satisfaction in current teaching assignment of early career teachers in Region $24(n=21)$

Factor

Frequency

Percentage

Higher salary

16

76.1

Support of other faculty members

13

61.9

Community/parent support

11

52.3

Administrative support

8

38.0

Participation in decision making

7

33.3

Recognition of accomplishments

Improved school environment

6

28.5

Support with discipline problems

6

28.5

Other

6

28.5

Adequate educational preparation for this teaching assignment 
Table 4.28: Continued

Factor

Frequency

Percentage

Fewer classes

3

14.2

Smaller classes

3

14.2

Tables 4.29 to 4.33 illustrate the factors contributing to greater job satisfaction in the five categories of Districts.

Table 4.29: Frequency and percentage of factors increasing job satisfaction in current teaching assignment of early career teachers in District A $(n=24)$

Factor

Frequency

Percentage

Community/parent support

14

58.3

Higher salary

14

58.3

Support of other faculty members

12

50.0

Recognition of accomplishments

11

45.8

Administrative support

9

37.5

Support with discipline problems

9

37.5

Other

9

37.5

Improved school environment

8

33.3

Participation in decision making

5

20.8

Adequate educational preparation

for this teaching assignment

3

12.5

Fewer classes

Smaller classes

2

8.3 
Table 4:30: Frequency and percentage of factors increasing job satisfaction in current teaching assignment of early career teachers in District B $(n=21)$

Factor

Frequency

Percentage

Community/parent support

12

57.1

Higher salary

11

52.3

Support of other faculty members

8

38.0

Improved school environment

8

38.0

Support with discipline problems

7

33.3

Administrative support

6

28.5

Participation in decision making

5

23.8

Recognition of accomplishments

5

23.8

Fewer classes

4

19.0

Smaller classes

4

19.0

Adequate educational preparation

for this teaching assignment

4

19.0

Other

2

9.5

Table 4.31: Frequency and percentage of factors increasing job satisfaction in current teaching assignment of early career teachers in District $C(n=25)$

Factor

Frequency

Percentage

Community/parent support

15

60.0

Higher salary

13

52.0 
Table 4.31: Continued

Factor

Frequency

Percentage

Administrative support

12

48.0

Improved school environment

12

48.0

Support with discipline problems

11

44.0

Support of other faculty members

10

40.0

Participation in decision making

36.0

Recognition of accomplishments

Other

Adequate educational preparation

for this teaching assignment

Fewer classes

Smaller classes

2

8.0

Table 4.32: Frequency and percentage of factors increasing job satisfaction in current teaching assignment of early career teachers in District $D(n=10)$

Factor

Frequency

Percentage

Higher salary

7

70.0

Administrative support

6

60.0

Community/parent support

6

60.0

Other

60.0

Participation in decision making

4

40.0 
Table 4.32: Continued

Factor

Frequency

Percentage

Recognition of accomplishments

3

30.0

Support of other faculty members

3

30.0

Support with discipline problems

30.0

Fewer classes

1

10.0

Smaller classes

1

10.0

Improved school environment

1

10.0

Adequate educational preparation

for this teaching assignment

1

10.0

Table 4.33: Frequency and percentage of factors increasing job satisfaction in current teaching assignment of early career teachers in Districts E - I $(n=7)$

Factor

Frequency

Percentage

Community/parent support

6

85.7

Higher salary

6

85.7

Administrative support

3

42.8

Support with discipline problems

3

42.8

Other

Participation in decision making

Recognition of accomplishments

2

28.5

Support of other faculty members 
Table 4.33: Continued

Factor

Frequency

Percentage

Fewer classes

1

14.2

Smaller classes

1

14.2

Improved school environment

1

14.2

Adequate educational preparation

for this teaching assignment

0

0.0

Factors contributing to greater job satisfaction as identified by School Type are presented in Tables 4.34 to 4.36 .

Table 4.34: Frequency and percentage of factors increasing job satisfaction in current teaching assignment of early career teachers in rural schools $(n=5)$

Factor

Frequency

Percentage

Community/parent support

5

100.00

Higher salary

4

80.0

Administrative support

3

60.0

Improved school environment

2

40.0

Support with discipline problems

2

40.0

Participation in decision making

40.0

Other

40.0

Smaller classes

1

20.0

Support of other faculty members

0

0.0 
Table 4.34: Continued

Factor

Frequency

Percentage

Fewer classes

0

0.0

Recognition of accomplishments

0

0.0

Adequate educational preparation

for this teaching assignment

0

0.0

Table 4:35: Frequency and percentage of factors increasing job satisfaction in current teaching assignment of early career teachers in suburban schools $(n=57)$

Factor

Frequency

Percentage

Community/parent support

34

59.6

Higher salary

32

56.1

Support of other faculty members

24

42.1

Administrative support

23

40.3

Support with discipline problems

22

38.5

Recognition of accomplishments

22

38.5

Participation in decision making

17

29.8

Improved school environment

13

22.8

Fewer classes

7

12.2

Smaller classes

6

10.5

Other

Adequate educational preparation for this teaching assignment 
Table 4.36: Frequency and percentage of factors increasing job satisfaction in current teaching assignment of early career teachers in urban schools $(n=25)$

Factor

Frequency

Percentage

Higher salary

15

60.0

Improved school environment

15

60.0

Community/parent support

14

56.0

Administrative support

10

40.0

Support of other faculty members

10

40.0

Support with discipline problems

9

36.0

Other

Participation in decision making

Recognition of accomplishments

6

24.0

Fewer classes

Smaller classes

3

12.0

Adequate educational preparation for this teaching assignment

2

8.0

Factors affecting job satisfaction by School Level are displayed in Tables 4.37 to 4.39. 
Table 4.37: Frequency and percentage of factors increasing job satisfaction in current teaching assignment of early career teachers in high schools $(n=26)$

Factor

Frequency

Percentage

Higher salary

16

61.5

Community/parent support

14

53.8

Support of other faculty members

Other

Administrative support

Support with discipline problems

Recognition of accomplishments

Participation in decision making

6

23.0

Fewer classes

4

15.3

Adequate educational preparation for this teaching assignment

Smaller classes

Improved school environment

2

7.6

Table 4.38: Frequency and percentage of factors increasing job satisfaction in current teaching assignment of early career teachers in junior high schools $(n=19)$

Factor

Frequency

Percentage

Community/parent support

13

68.4

Higher salary

12

63.1 
Table 4.38: Continued

Factor

Frequency

Percentage

Recognition of accomplishments

Support of other faculty members

Administrative support

Support with discipline problems

8

42.1

Other

Improved school environment

Participation in decision making

Smaller classes

Adequate educational preparation for this teaching assignment

Fewer classes

1

Table 4.39: Frequency and percentage of factors increasing job satisfaction in current teaching assignment of early career teachers in middle schools $(n=42)$

Factor

Higher salary

Administrative support

Support with discipline problems 
Table 4.39: Continued

Factor

Frequency

Percentage

Participation in decision making

Support of other faculty members

14

33.3

Recognition of accomplishments

11

26.1

Other

9

21.4

Fewer classes

6

14.2

Smaller classes

6

Adequate educational preparation

for this teaching assignment

5

11.9

Tables 4.40 to 4.44 display factors contributing to improved job satisfaction in the five Conferences.

Table 4.40: Frequency and percentage of factors increasing job satisfaction in current teaching assignment of early career teachers in Conference AA - AAAA schools $(n=13)$

Factor

Frequency

Percentage

Higher salary

10

76.9

Administrative support

8

61.5

Community/parent support

8

61.5

Support of other faculty members

7

53.8

Other

6

46.1 
Table 4.40: Continued

Factor

Frequency

Percentage

Recognition of accomplishments

5

38.4

Improved school environment

4

30.7

Support with discipline problems

Fewer classes

2

15.3

Participation in decision making

Smaller classes

0

0.0

Adequate educational preparation

for this teaching assignment

0

0.0

Table 4.41: Frequency and percentage of factors increasing job satisfaction in current teaching assignment of early career teachers in Conference AAAAA schools $(\mathrm{n}=13)$

Factor

Frequency

Percentage

Community/parent support

6

46.1

Higher salary

6

46.1

Improved school environment

5

38.4

Other

5

38.4

Support with discipline problems

4

30.7

Participation in decision making

4

30.7

Support of other faculty members

4

30.7 
Table 4.41: Continued

Factor

Frequency

Percentage

Adequate educational preparation

for this teaching assignment

4

30.7

Smaller classes

2

15.3

Administrative support

2

15.3

Recognition of accomplishments

2

15.3

Fewer classes

1

7.6

Table 4.42: Frequency and percentage of factors increasing job satisfaction in current teaching assignment of early career teachers in Conference BB - BBB schools $(n=6)$

Factor

Frequency

Percentage

Community/parent support

5

83.3

Support of other faculty members

3

50.0

Higher salary

3

50.0

Other

50.0

Administrative support

2

33.3

Recognition of accomplishments

2

33.3

Improved school environment

1

16.6

Support with discipline problems

1

16.6

Participation in decision making

1

16.6 
Table 4.42: Continued

Factor

Frequency

Percentage

Fewer classes

0

0.0

Smaller classes

0

0.0

Adequate educational preparation

for this teaching assignment

0

0.0

Table 4.43: Frequency and percentage of factors increasing job satisfaction in current teaching assignment of early career teachers in Conference $\mathrm{CC}$ schools $(n=26)$

Factor

Frequency

Percentage

Community/parent support

17

65.3

Higher salary

17

65.3

Administrative support

13

50.0

Support with discipline problems

12

46.1

Support of other faculty members

10

38.4

Improved school environment

10

38.4

Recognition of accomplishments

9

34.6

Participation in decision making

8

30.7

Fewer classes

5

19.2

Other

5

19.2

Adequate educational preparation

for this teaching assignment

4

15.3

Smaller classes

3 
Table 4.44: Frequency and percentage of factors increasing job satisfaction in current teaching assignment of early career teachers in Conference CCC schools $(n=29)$

Factor

Frequency

Percentage

Community/parent support

17

58.6

Higher salary

15

51.7

Support with discipline problems

13

44.8

Administrative support

11

37.9

Support of other faculty members

10

34.4

Improved school environment

10

34.4

Participation in decision making

10

34.4

Recognition of accomplishments

10

34.4

Other

8

27.5

Smaller classes

17.2

Adequate educational preparation for this teaching assignment

Fewer classes

Factors increasing job satisfaction in accordance with Years of Teaching Experience are shown in Tables 4.45 to 4.49 . 
Table 4.45: Frequency and percentage of factors increasing job satisfaction in current teaching assignment of early career teachers with 1 to 1.5 years of teaching experience $(n=16)$

Factor

Frequency

Percentage

Community/parent support

10

62.5

Higher salary

9

56.2

Support of other faculty members

8

50.0

Improved school environment

7

43.7

Support with discipline problems

7

43.7

Participation in decision making

6

37.5

Other

6

37.5

Recognition of accomplishments

5

31.2

Administrative support

4

25.0

Adequate educational preparation for this teaching assignment

Fewer classes

Smaller classes 
Table 4.46: Frequency and percentage of factors increasing job satisfaction in current teaching assignment of early career teachers with 2 years of teaching experience $(n=18)$

Factor

Frequency

Percentage

Community/parent support

12

66.6

Higher salary

10

55.5

Administrative support

7

38.8

Improved school environment

7

38.8

Support of other faculty members

5

27.7

Recognition of accomplishments

5

27.7

Support with discipline problems

4

22.2

Other

4

22.2

Fewer classes

16.6

Smaller classes

16.6

Participation in decision making

16.6

Adequate educational preparation for this teaching assignment 
Table 4.47: Frequency and percentage of factors increasing job satisfaction in current teaching assignment of early career teachers with 3 to 3.5 years of teaching experience $(n=20)$

Factor

Frequency

Percentage

Higher salary

12

60.0

Community/parent support

11

55.0

Support with discipline problems

10

50.0

Support of other faculty members

9

45.0

Administrative support

8

40.0

Recognition of accomplishments

8

40.0

Improved school environment

6

30.0

Participation in decision making

6

30.0

Other

6

30.0

Adequate educational preparation

for this teaching assignment

3

15.0

Smaller classes

2

10.0

Fewer classes

1 
Table 4.48: Frequency and percentage of factors increasing job satisfaction in current teaching assignment of early career teachers with 4 years of teaching experience $(n=13)$

Factor

Frequency

Percentage

Administrative support

9

69.2

Community/parent support

9

69.2

Higher salary

8

61.5

Improved school environment

6

46.1

Support of other faculty members

5

38.4

Participation in decision making

5

38.4

Recognition of accomplishments

5

38.4

Support with discipline problems

4

30.7

Other

4

30.7

Fewer classes

3

23.0

Adequate educational preparation

for this teaching assignment

Smaller classes

0

0.0 
Table 4.49: Frequency and percentage of factors increasing job satisfaction in current teaching assignment of early career teachers with 5 years of teaching experience $(n=20)$

\begin{tabular}{llc}
\hline Factor & Frequency & Percentage \\
\hline Higher salary & 12 & 60.0 \\
Community/parent support & 11 & 55.0 \\
Administrative support & 8 & 40.0 \\
Support of other faculty members & 7 & 35.0 \\
Participation in decision making & 6 & 30.0 \\
Other & 6 & 30.0 \\
Support with discipline problems & 5 & 25.0 \\
Recognition of accomplishments & 5 & 25.0 \\
Improved school environment & 3 & 20.0 \\
$\begin{array}{l}\text { Adequate educational preparation } \\
\text { for this teaching assignment }\end{array}$ & 4 & 20.0 \\
Smaller classes & & 5.0 \\
\hline Fewer classes & & \\
\hline
\end{tabular}

Tables 4.50 to 4.54 present the factors increasing job satisfaction by Number of Years in Current Teaching Position. 
Table 4.50: Frequency and percentage of factors increasing job satisfaction of early career teachers teaching in current school from 1 to 1.5 years $(n=34)$

Factor

Frequency

Percentage

Community/parent support

27

79.4

Higher salary

20

58.8

Other

13

38.2

Administrative support

12

35.2

Support of other faculty members

11

32.3

Improved school environment

11

32.3

Support with discipline problems

11

32.3

Recognition of accomplishments

8

23.5

Smaller classes

6

17.6

Participation in decision making

6

17.6

Fewer classes

3

8.8

Adequate educational preparation

for this teaching assignment

3

8.8

Table 4.51: Frequency and percentage of factors increasing job satisfaction of early career teachers teaching in current school for 2 years $(n=22)$

Factor

Frequency

Percentage

Higher salary

14

63.6

Community/parent support

12

54.5 
Table 4.51: Continued

Factor

Frequency

Percentage

Support of other faculty members

10

45.4

Participation in decision making

10

45.4

Recognition of accomplishments

10

45.4

Administrative support

8

36.3

Support with discipline problems

8

36.3

Improved school environment

6

27.2

Other

6

27.2

Adequate educational preparation

for this teaching assignment

5

22.7

Fewer classes

4

18.1

Smaller classes

4

18.1

Table 4.52: Frequency and percentage of factors increasing job satisfaction of early career teachers teaching in current school for 3 to 3.5 years $(n=20)$

Factor

Frequency

Percentage

Community/parent support

13

65.0

Support with discipline problems

13

65.0

Administrative support

11

55.0

Higher salary

10

50.0

Improved school environment

10

50.0 
Table 4.52: Continued

Factor

Frequency

Percentage

Participation in decision making

10

50.0

Support of other faculty members

8

40.0

Adequate educational preparation

for this teaching assignment

6

30.0

Other

6

30.0

Recognition of accomplishments

4

20.0

Fewer classes

2

10.0

Smaller classes

1

5.0

Table 4.53: Frequency and percentage of factors increasing job satisfaction of early career teachers teaching in current school for 4 years $(n=6)$

Factor

Frequency

Percentage

Higher salary

5

83.3

Support of other faculty members

3

50.0

Community/parent support

3

50.0

Recognition of accomplishments

3

50.0

Administrative support

2

33.3

Other

2

33.3

Fewer classes

1

16.6

Improved school environment

1

16.6 
Table 4.53: Continued

Factor

Frequency

Percentage

Participation in decision making

1

16.6

Adequate educational preparation

for this teaching assignment

1

16.6

Smaller classes

0

0.0

Support with discipline problems

0

0.0

Table 4.54: Frequency and percentage of factors increasing job satisfaction of early career teachers teaching in current school for 5 years $(n=5)$

Factor

Frequency

Percentage

Administrative support

3

60.0

Participation in decision making

3

60.0

Support of other faculty members

2

40.0

Community/parent support

2

40.0

Higher salary

2

40.0

Improved school environment

2

40.0

Smaller classes

1

20.0

Support with discipline problems

1

20.0

Recognition of accomplishments

1

20.0

Adequate educational preparation

for this teaching assignment

1

20.0 
Table 4.54: Continued

Factor

Frequency

Percentage

Fewer classes

0

0.0

Other

0

0.0

Tables 4.55 and 4.56 present the factors increasing job satisfaction in terms of

Position on Choral Staff.

Table 4.55: Frequency and percentage of factors increasing job satisfaction in current teaching assignment of early career teachers who are the head director $(\mathrm{n}=58)$

Factor

Frequency

Percentage

Community/parent support

40

68.9

Higher salary

35

60.3

Administrative support

Support with discipline problems

Support of other faculty members

Improved school environment

Participation in decision making

Recognition of accomplishments

Other

Fewer classes 
Table 4.55: Continued

Factor

Frequency

Percentage

Adequate educational preparation

for this teaching assignment

Table 4.56: Frequency and percentage of factors increasing job satisfaction in current teaching assignment of early career teachers who are the assistant director $(\mathrm{n}=29)$

Factor

Frequency

Percentage

Higher salary

16

55.1

Community/parent support

13

44.8

Support of other faculty members

11

37.9

Improved school environment

10

34.4

Recognition of accomplishments

9

31.0

Other

Administrative support

Support with discipline problems

Participation in decision making

Adequate educational preparation for this teaching assignment

Smaller classes

Fewer classes 
Factors increasing job satisfaction in accordance with Number of People on

Choral Staff are displayed in Tables 4.57 and 4.58.

Table 4.57: Frequency and percentage of factors increasing job satisfaction in current teaching assignment of early career teachers with one person on the choral staff $(n=46)$

Factor

Frequency

Percentage

Community/parent support

33

71.7

Higher salary

25

54.3

Administrative support

21

45.6

Support with discipline problems

Participation in decision making

Recognition of accomplishments

19

41.3

Other

18

39.1

Support of other faculty members

Improved school environment

Fewer classes

Smaller classes

Adequate educational preparation for this teaching assignment 
Table 4.58: Frequency and percentage of factors increasing job satisfaction in current teaching assignment of early career teachers with 1.5 to 3 people on the choral staff $(n=41)$

Factor

Frequency

Percentage

Higher salary

26

63.4

Community/parent support

20

48.7

Support of other faculty members

17

41.4

Administrative support

Improved school environment

Other

Support with discipline problems

Recognition of accomplishments

29.2

Participation in decision making

Adequate educational preparation for this teaching assignment

Smaller classes

Fewer classes

\section{Methods of Professional Assistance}

Early career teachers were given a checklist of 19 types of professional assistance compiled by the researcher and were asked to indicate which were provided in their school (See Table 4.56). The vast majority of teachers indicated that methods of assistance in their school included in-service programs $(98.8 \%)$, other music teachers in 
their school (96.5\%), colleagues in the music field (93.1\%), new teacher orientations programs (91.9\%), and the accessibility of their administrators $(90.8 \%)$. The majority of teachers also received assistance in the form of other non-music teachers in school (88.5\%), fine arts supervisors (86.2\%), administrators' visits to classroom (85.0\%), music workshops or conferences $(81.6 \%)$, release time for performances outside of school (71.2\%), and assigned music teacher mentors (52.8\%).

Less than half of the teachers reported having administrative assistance with classroom management (48.2\%), assigned non-music teacher mentors (43.6\%), release time for recruiting students from other schools (41.3\%), release time to work with feeder school choirs (40.2\%), and release time to observe experienced music teachers $(37.9 \%)$. The least frequently selected forms of assistance included assistance with administrative duties (fundraising, trips, competitions) (19.5\%), administrative assistance with budget preparation $(17.2 \%)$, and administrative assistance with large classes (13.7\%).

Table 4.59: Frequency and percentage of methods of professional assistance provided for early career teachers $(n=87)$

\begin{tabular}{lcc}
\hline \multicolumn{1}{c}{ Method } & Frequency & Percentage \\
\hline In-service programs & 86 & 98.8 \\
Other music teachers in school & 84 & 96.5 \\
Colleagues in music field & 81 & 93.1 \\
New teacher orientation program & 80 & 91.9 \\
Accessibility of administrator & 79 & 90.8 \\
Other non-music teachers in school & 77 & 88.5
\end{tabular}


Table 4.59: Continued

\begin{tabular}{|c|c|c|}
\hline Method & Frequency & Percentage \\
\hline Fine arts supervisor & 75 & 86.2 \\
\hline Administrators' visits to classroom & 74 & 85.0 \\
\hline Music workshops or conferences & 71 & 81.6 \\
\hline Release time for performances outside of school & 62 & 71.2 \\
\hline Assigned mentor teacher (music) & 46 & 52.8 \\
\hline $\begin{array}{l}\text { Administrative assistance with } \\
\text { classroom management }\end{array}$ & 42 & 48.2 \\
\hline Assigned mentor teacher (non-music) & 38 & 43.6 \\
\hline $\begin{array}{l}\text { Release time for recruiting students } \\
\text { from other schools }\end{array}$ & 36 & 41.3 \\
\hline Release time to work with feeder school choirs & 35 & 40.2 \\
\hline $\begin{array}{l}\text { Release time to observe experienced } \\
\text { music teachers }\end{array}$ & 33 & 37.9 \\
\hline $\begin{array}{l}\text { Assistance with administrative duties } \\
\text { (fundraising, trips, competitions) }\end{array}$ & 17 & 19.5 \\
\hline $\begin{array}{l}\text { Administrative assistance with } \\
\text { budget preparation }\end{array}$ & 15 & 17.2 \\
\hline Administrative assistance with large classes & 12 & 13.7 \\
\hline
\end{tabular}

Examination of methods of professional assistance was conducted for each subgroup. Methods of assistance provided for each of the five Regions is presented in Tables 4.60 to 4.64 . 
Table 4.60: Methods of professional assistance provided for early career teachers in Region $3(n=20)$

Method

Frequency

Percentage

New teacher orientation program

20

100.0

In service programs

19

95.0

Other music teachers in school

19

95.0

Colleagues in music field

19

95.0

Accessibility of administrator

19

95.0

Fine arts supervisor

18

90.0

Other non-music teachers in school

18

90.0

Music workshops or conferences

17

85.0

Administrators' visits to classroom

16

80.0

Assigned mentor teacher (music)

65.0

Release time to observe experienced

13

65.0

music teachers

Release time to work with feeder school choirs

Release time for performances outside of school

Administrative assistance with

classroom management

60.0

Assigned mentor teacher (non-music)

Release time for recruiting students

from other schools

Administrative assistance with

budget preparation

25.0

Assistance with administrative duties

(fundraising, trips, competitions)

Administrative assistance with large classes

15.0 
Table 4.61: Methods of professional assistance provided for early career teachers in Region $5(\mathrm{n}=27)$

Method

Frequency

Percentage

In-service programs

27

100.0

Fine arts supervisor

27

100.0

Other music teachers in school

25

92.5

Colleagues in music field

25

92.5

Administrators' visits to classroom

24

88.8

Accessibility of administrator

23

85.1

New teacher orientation program

23

85.1

Release time for performances outside of school

22

81.4

Other non-music teachers in school

21

77.7

Music workshops or conferences

20

74.0

Release time for recruiting students

from other schools

15

55.5

Administrative assistance with classroom management

12

44.4

Assigned mentor teacher (music)

11

40.7

Assigned mentor teacher (non-music)

10

37.0

Release time to observe experienced

8

29.6

music teachers

Release time to work with feeder school choirs

8

29.6

Assistance with administrative duties

(fundraising, trips, competitions)

18.5

Administrative assistance with

budget preparation

Administrative assistance with large classes 
Table 4.62: Methods of professional assistance provided for early career teachers in Region 7 ( $n=6$ )

\begin{tabular}{|c|c|c|}
\hline Method & Frequency & Percentage \\
\hline In-service programs & 6 & 100.0 \\
\hline Other non-music teachers in school & 6 & 100.0 \\
\hline Other music teachers in school & 5 & 83.3 \\
\hline Colleagues in music field & 5 & 83.3 \\
\hline Music workshops or conferences & 5 & 83.3 \\
\hline Accessibility of administrator & 5 & 83.3 \\
\hline Administrators' visits to classroom & 5 & 83.3 \\
\hline Assigned mentor teacher (non-music) & 4 & 66.6 \\
\hline New teacher orientation program & 4 & 66.6 \\
\hline Release time for performances outside of school & 3 & 50.0 \\
\hline Fine arts supervisor & 2 & 33.3 \\
\hline $\begin{array}{l}\text { Release time to observe experienced } \\
\text { music teachers }\end{array}$ & 2 & 33.3 \\
\hline $\begin{array}{l}\text { Administrative assistance with } \\
\text { classroom management }\end{array}$ & 2 & 33.3 \\
\hline Release time to work with feeder school choirs & 2 & 33.3 \\
\hline Assigned mentor teacher (music) & 1 & 16.6 \\
\hline $\begin{array}{l}\text { Administrative assistance with } \\
\text { budget preparation }\end{array}$ & 1 & 16.6 \\
\hline $\begin{array}{l}\text { Release time for recruiting students } \\
\text { from other schools }\end{array}$ & 1 & 16.6 \\
\hline $\begin{array}{l}\text { Assistance with administrative duties } \\
\text { (fundraising, trips, competitions) }\end{array}$ & 0 & 0.0 \\
\hline Administrative assistance with large classes & 0 & 0.0 \\
\hline
\end{tabular}


Table 4.63: Methods of professional assistance provided for early career teachers in Region $20(n=13)$

Method

Other music teachers in school

New teacher orientation program

Other non-music teachers in school

In-service programs

Colleagues in music field

Music workshops or conferences

Accessibility of administrator

Fine arts supervisor

Release time for performances outside of school

Assigned mentor teacher (music)

Administrators' visits to classroom

Assigned mentor teacher (non-music)

Release time for recruiting students

from other schools

Release time to observe experienced

music teachers

Administrative assistance with classroom management

Assistance with administrative duties (fundraising, trips, competitions)

Release time to work with feeder school choirs

Administrative assistance with budget preparation

Administrative assistance with large classes
Frequency

13

13

12

11

11

11

11

10

10

9

9

7

5

4

4

4

4

2

2
38.4

30.7

30.7

30.7

30.7

15.3

100.0

100.0

92.3

84.6

84.6

84.6

84.6

76.9

76.9

69.2

69.2

53.8

8.4

0.7

15.3 
Table 4.64: Methods of professional assistance provided for early career teachers in Region $24(n=21)$

\begin{tabular}{|c|c|c|}
\hline Method & Frequency & Percentage \\
\hline In-service programs & 21 & 100.0 \\
\hline Other music teachers in school & 21 & 100.0 \\
\hline Colleagues in music field & 21 & 100.0 \\
\hline Accessibility of administrator & 21 & 100.0 \\
\hline Administrators' visits to classroom & 20 & 95.2 \\
\hline New teacher orientation program & 20 & 95.2 \\
\hline Other non-music teachers in school & 20 & 95.2 \\
\hline Fine arts supervisor & 18 & 85.7 \\
\hline Music workshops or conferences & 18 & 85.7 \\
\hline Release time for performances outside of school & 15 & 71.4 \\
\hline Assigned mentor teacher (music) & 12 & 57.1 \\
\hline $\begin{array}{l}\text { Administrative assistance with } \\
\text { classroom management }\end{array}$ & 12 & 57.1 \\
\hline $\begin{array}{l}\text { Release time for recruiting students } \\
\text { from other schools }\end{array}$ & 8 & 38.0 \\
\hline Release time to work with feeder school choirs & 7 & 33.3 \\
\hline $\begin{array}{l}\text { Release time to observe experienced } \\
\text { music teachers }\end{array}$ & 6 & 28.5 \\
\hline Assigned mentor teacher (non-music) & 6 & 28.5 \\
\hline Administrative assistance with large classes & 6 & 28.5 \\
\hline $\begin{array}{l}\text { Assistance with administrative duties } \\
\text { (fundraising, trips, competitions) }\end{array}$ & 4 & 19.0 \\
\hline $\begin{array}{l}\text { Administrative assistance with } \\
\text { budget preparation }\end{array}$ & 3 & 14.2 \\
\hline
\end{tabular}

Methods of professional assistance provided for each of the five Districts is presented in Tables 4.65 to 4.69 . 
Table 4.65: Methods of professional assistance provided for early career teachers in District A schools $(n=24)$

Method

Frequency

Percentage

Fine arts supervisor 24

100.0

In-service programs

23

95.8

Other music teachers in school

22

91.6

Colleagues in music field

22

91.6

Administrators' visits to classroom

21

87.5

New teacher orientation program

20

83.3

Music workshops or conferences

19

79.1

Accessibility of administrator

19

79.1

Other non-music teachers in school

18

75.0

Release time for performances outside of school

16

66.6

Assigned mentor teacher (music)

Release time for recruiting students

from other schools

Administrative assistance with classroom management

Assigned mentor teacher (non-music)

Release time to work with feeder school choirs

Assistance with administrative duties

(fundraising, trips, competitions)

Release time to observe experienced

music teachers

Administrative assistance with budget preparation 
Table 4.66: Methods of professional assistance provided for early career teachers in District B schools $(n=21)$

\begin{tabular}{|c|c|c|}
\hline Method & Frequency & Percentage \\
\hline In-service programs & 21 & 100.0 \\
\hline New teacher orientation program & 21 & 100.0 \\
\hline Fine arts supervisor & 21 & 100.0 \\
\hline Colleagues in music field & 21 & 100.0 \\
\hline Other music teachers in school & 20 & 95.2 \\
\hline Other non-music teachers in school & 20 & 95.2 \\
\hline Accessibility of administrator & 20 & 95.2 \\
\hline Music workshops or conferences & 18 & 85.7 \\
\hline Administrators' visits to classroom & 17 & 80.9 \\
\hline Release time for performances outside of school & 14 & 66.6 \\
\hline $\begin{array}{l}\text { Administrative assistance with } \\
\text { classroom management }\end{array}$ & 12 & 57.1 \\
\hline Assigned mentor teacher (non-music) & 11 & 52.3 \\
\hline Assigned mentor teacher (music) & 10 & 47.6 \\
\hline $\begin{array}{l}\text { Release time for recruiting students } \\
\text { from other schools }\end{array}$ & 9 & 42.8 \\
\hline Release time to work with feeder school choirs & 9 & 42.8 \\
\hline $\begin{array}{l}\text { Release time to observe experienced } \\
\text { music teachers }\end{array}$ & 7 & 33.3 \\
\hline $\begin{array}{l}\text { Administrative assistance with } \\
\text { budget preparation }\end{array}$ & 4 & 19.0 \\
\hline $\begin{array}{l}\text { Assistance with administrative duties } \\
\text { (fundraising, trips, competitions) }\end{array}$ & 4 & 19.0 \\
\hline Administrative assistance with large classes & 4 & 19.0 \\
\hline
\end{tabular}


Table 4.67: Methods of professional assistance provided for early career teachers in District C schools $(\mathrm{n}=25)$

Method

Frequency

Percentage

New teacher orientation program

25

23

21

19

11

11

budget preparation

Assistance with administrative duties

(fundraising, trips, competitions)

Administrative assistance with large classes
25

25

24

24

23

23

15

13

13

10

5

100.0

100.0

100.0

96.0

96.0

92.0

92.0

92.0

84.0

76.0

60.0

52.0

52.0

40.0

44.0

44.0

20.0

20.0

5

20.0 
Table 4.68: Methods of professional assistance provided for early career teachers in District D schools $(n=10)$

Method

Frequency

Percentage

Other music teachers in school

100.0

Colleagues in music field

10

100.0

In-service programs

9

90.0

New teacher orientation program

90.0

Other non-music teachers in school

90.0

Music workshops or conferences

Accessibility of administrator

90.0

Release time for performances outside of school

Administrators' visits to classroom

Release time to work with feeder school choirs

Release time for recruiting students

from other schools

Assigned mentor teacher (music)

Release time to observe experienced

music teachers

Assigned mentor teacher (non-music)

Fine arts supervisor

Administrative assistance with classroom management

Administrative assistance with budget preparation

Assistance with administrative duties (fundraising, trips, competitions) 
Table 4.69: Methods of professional assistance provided for early career teachers in District E - I schools $(n=7)$

Method

Frequency

Percentage

In-service programs

7

100.0

Other non-music teachers in school 7

100.0

Other music teachers in school 6

85.7

Accessibility of administrator 6

85.7

Administrators' visits to classroom

6

85.7

Administrative assistance with classroom management

New teacher orientation program 5

71.4

Colleagues in music field 5

71.4

Assigned mentor teacher (non-music) 5

71.4

Release time for performances outside of school 5

71.4

Music workshops or conferences

Release time to observe experienced music teachers

Fine arts supervisor

Assigned mentor teacher (music)

Administrative assistance with budget preparation

Assistance with administrative duties (fundraising, trips, competitions)

Administrative assistance with large classes

Release time to work with feeder school choirs

Release time for recruiting students from other schools

Methods of professional assistance by School Type are shown in Tables 4.70 to 4.72 . 
Table 4.70: Methods of professional assistance provided for early career teachers in rural schools $(n=5)$

Method

Frequency

Percentage

In-service programs

5

100.0

Other non-music teachers in school

5

100.0

Other music teachers in school

4

80.0

Colleagues in music field

4

80.0

Music workshops or conferences

4

80.0

Accessibility of administrator

4

80.0

Administrators' visits to classroom

4

80.0

New teacher orientation program

3

60.0

Assigned mentor teacher (non-music)

3

60.0

Release time for performances outside of school

3

60.0

Fine arts supervisor

2

40.0

Release time to observe experienced

music teachers

40.0

Administrative assistance with

classroom management

40.0

Administrative assistance with

budget preparation

2

40.0

Assigned mentor teacher (music)

20.0

Assistance with administrative duties

(fundraising, trips, competitions)

1

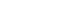

Administrative assistance with large classes

0

0.0

0

0.0

Release time to work with feeder school choirs

0

0.0

Release time for recruiting students

from other schools

0

0.0 
Table 4.71: Methods of professional assistance provided for early career teachers in suburban schools $(n=57)$

Method

Frequency

Percentage

Other music teachers in school

In-service programs

96.4

Colleagues in music field

96.4

New teacher orientation program

Accessibility of administrator

Other non-music teachers in school

Fine arts supervisor

Administrators' visits to classroom

Music workshops or conferences

Release time for performances outside of school

Administrative assistance with classroom management

Assigned mentor teacher (music)

Release time for recruiting students from other schools

Release time to work with feeder school choirs

Assigned mentor teacher (non-music)

Release time to observe experienced

Assistance with administrative duties (fundraising, trips, competitions)

Administrative assistance with budget preparation 
Table 4.72: Methods of professional assistance provided for early career teachers in urban schools $(n=25)$

Method

Frequency

Percentage

In-service programs

24

96.0

New teacher orientation program

24

96.0

Fine arts supervisor

23

92.0

Other music teachers in school

23

92.0

Music workshops or conferences

23

92.0

Colleagues in music field

88.0

Accessibility of administrator

22

88.0

Administrators' visits to classroom

21

84.0

Other non-music teachers in school

20

80.0

Assigned mentor teacher (music)

16

64.0

Release time for performances outside of school

16

64.0

Assigned mentor teacher (non-music)

11

44.0

Administrative assistance with

classroom management

10

40.0

Release time to work with feeder school choirs

10

40.0

Release time for recruiting students

from other schools

10

40.0

Release time to observe experienced

9

36.0

music teachers

Assistance with administrative duties

(fundraising, trips, competitions)

Administrative assistance with

budget preparation

12.0

Administrative assistance with large classes

3

12.0

Tables 4.73 to 4.75 present methods of professional assistance by School Level. 
Table 4.73: Methods of professional assistance provided for early career teachers in high schools $(n=26)$

Method

Frequency

Percentage

In-service programs

26

100.0

Accessibility of administrator

25

96.1

Administrators' visits to classroom

25

96.1

Other music teachers in school

Colleagues in music field

24

92.3

New teacher orientation program

23

88.4

Other non-music teachers in school

88.4

Music workshops or conferences

23

88.4

Release time for performances outside of school

22

84.6

Fine arts supervisor

76.9

Assigned mentor teacher (music)

17

65.3

Release time to work with feeder school choirs

17

65.3

Administrative assistance with

classroom management

12

46.1

Release time for recruiting students

from other schools

11

42.3

Assigned mentor teacher (non-music)

10

38.4

Release time to observe experienced

10

38.4

music teachers

Administrative assistance with

budget preparation

5

19.2

Assistance with administrative duties

(fundraising, trips, competitions)

19.2

Administrative assistance with large classes 
Table 4.74: Methods of professional assistance provided for early career teachers in junior high schools $(n=19)$

Method

Frequency

Percentage

In-service programs

19

100.0

Fine arts supervisor

18

94.7

Other music teachers in school

17

89.4

Other non-music teachers in school

89.4

Colleagues in music field

89.4

New teacher orientation program

16

84.4

Accessibility of administrator

15

78.9

Administrators' visits to classroom

15

78.9

Music workshops or conferences

13

68.4

Release time for performances outside of school

68.4

Administrative assistance with classroom management

Assigned mentor teacher (non-music)

Release time for recruiting students from other schools

Release time to observe experienced

music teachers

Release time to work with feeder school choirs

Assigned mentor teacher (music)

Assistance with administrative duties (fundraising, trips, competitions)

Administrative assistance with large classes

Administrative assistance with budget preparation 
Table 4.75: Methods of professional assistance provided for early career teachers in middle schools $(n=42)$

\begin{tabular}{|c|c|c|}
\hline Method & Frequency & Percentage \\
\hline Other music teachers in school & 42 & 100.0 \\
\hline New teacher orientation program & 41 & 97.6 \\
\hline Colleagues in music field & 40 & 95.2 \\
\hline In-service programs & 39 & 92.8 \\
\hline Accessibility of administrator & 39 & 92.8 \\
\hline Fine arts supervisor & 37 & 88.0 \\
\hline Other non-music teachers in school & 37 & 88.0 \\
\hline Music workshops or conferences & 35 & 83.3 \\
\hline Administrators' visits to classroom & 34 & 80.9 \\
\hline Release time for performances outside of school & 27 & 64.2 \\
\hline Assigned mentor teacher (music) & 24 & 57.1 \\
\hline Assigned mentor teacher (non-music) & 19 & 45.2 \\
\hline $\begin{array}{l}\text { Administrative assistance with } \\
\text { classroom management }\end{array}$ & 18 & 42.8 \\
\hline $\begin{array}{l}\text { Release time to observe experienced } \\
\text { music teachers }\end{array}$ & 17 & 40.4 \\
\hline $\begin{array}{l}\text { Release time for recruiting students } \\
\text { from other schools }\end{array}$ & 16 & 38.0 \\
\hline Release time to work with feeder school choirs & 11 & 26.1 \\
\hline $\begin{array}{l}\text { Administrative assistance with } \\
\text { budget preparation }\end{array}$ & 10 & 23.8 \\
\hline $\begin{array}{l}\text { Assistance with administrative duties } \\
\text { (fundraising, trips, competitions) }\end{array}$ & 9 & 21.4 \\
\hline Administrative assistance with large classes & 9 & 21.4 \\
\hline
\end{tabular}

Tables 4.76 to 4.80 display methods of professional assistance in each of the five Conferences. 
Table 4.76: Methods of professional assistance provided for early career teachers in Conference AA to AAAA schools $(n=13)$

Method

Frequency

Percentage

In-service programs

13

100.0

Accessibility of administrator

13

100.0

Administrators' visits to classroom

13

100.0

Colleagues in music field

12

92.3

Release time for performances outside of school

12

92.3

New teacher orientation program

11

84.6

Other music teachers in school

11

84.6

Other non-music teachers in school

11

84.6

Music workshops or conferences

11

84.6

Fine arts supervisor

Assigned mentor teacher (music)

Release time to work with feeder school choirs

Release time for recruiting students

from other schools

Release time to observe experienced

46.1

music teachers

6

46.1

classroom management

38.4

Assigned mentor teacher (non-music)

5

30.7

Administrative assistance with

budget preparation

(fundraising, trips, competitions) 
Table 4.77: Methods of professional assistance provided for early career teachers in Conference AAAAA high schools $(n=13)$

Method

Frequency

Percentage

In-service programs

13

100.0

Fine arts supervisor

13

100.0

Other music teachers in school

13

100.0

New teacher orientation program

12

92.3

Other non-music teachers in school

12

92.3

Colleagues in music field

12

92.3

Music workshops or conferences

12

92.3

Accessibility of administrator

12

92.3

Administrators' visits to classroom

Assigned mentor teacher (music)

Release time to work with feeder school choirs

10

76.9

Release time for performances outside of school

10

76.9

Administrative assistance with classroom management

Assigned mentor teacher (non-music)

38.4

Release time for recruiting students

from other schools

Release time to observe experienced

music teachers

Assistance with administrative duties

(fundraising, trips, competitions)

Administrative assistance with large classes

Administrative assistance with budget preparation 
Table 4.78: Methods of professional assistance provided for early career teachers in Conference BB and BBB schools $(n=6)$

Method

Frequency

Percentage

In-service programs

6

100.0

New teacher orientation program

6

100.0

Fine arts supervisor

6

100.0

Other non-music teachers in school

6

100.0

Accessibility of administrator

6

100.0

Administrators' visits to classroom

6

100.0

Other music teachers in school

5

83.3

Colleagues in music field

5

83.3

Administrative assistance with classroom management

Assigned mentor teacher (non-music)

Music workshops or conferences

Release time to observe experienced

50.0

music teachers

Release time for performances outside of school

Release time for recruiting students

from other schools

Release time to work with feeder school choirs

Assigned mentor teacher (music)

Administrative assistance with budget preparation

Assistance with administrative duties

(fundraising, trips, competitions) 
Table 4.79: Methods of professional assistance provided for early career teachers in Conference CC schools $(n=26)$

Method Frequency Percentage

Other music teachers in school 26

100.0

In-service programs

25

96.1

New teacher orientation program

25

96.1

Colleagues in music field

88.4

Accessibility of administrator

88.4

Administrators' visits to classroom

88.4

Fine arts supervisor

Other non-music teachers in school

Music workshops or conferences

Release time for performances outside of school

Administrative assistance with classroom management

Assigned mentor teacher (music)

Assigned mentor teacher (non-music)

Release time to observe experienced

music teachers

Release time for recruiting students

from other schools

Release time to work with feeder school choirs

Administrative assistance with budget preparation

Administrative assistance with large classes

Assistance with administrative duties (fundraising, trips, competitions) 
Table 4.80: Methods of professional assistance provided for early career teachers in Conference CCC schools ( $\mathrm{n}=29)$

Method

Frequency

Percentage

Colleagues in music field

29

100.0

Other music teachers in school

96.5

In-service programs

27

93.1

Fine arts supervisor

New teacher orientation program

26

89.6

Other non-music teachers in school

26

89.6

Music workshops or conferences

25

86.2

Accessibility of administrator

25

86.2

Administrators' visits to classroom

20

68.9

Release time for performances outside of school

20

68.9

Assigned mentor teacher (music)

15

51.7

Assigned mentor teacher (non-music)

12

41.3

Release time for recruiting students

from other schools

12

41.3

Administrative assistance with classroom management

Release time to observe experienced

music teachers

Assistance with administrative duties

(fundraising, trips, competitions)

Release time to work with feeder school choirs

Administrative assistance with budget preparation

17.2

Administrative assistance with large classes

17.2

Methods of professional assistance in terms of Years of Teaching Experience are shown in Tables 4.81 to 4.85 . 
Table 4.81: Methods of professional assistance provided for early career teachers with 1 to 1.5 years of teaching experience $(n=16)$

Method

Frequency

Percentage

New teacher orientation program

16

100.0

Other non-music teachers in school

16

100.0

Colleagues in music field

16

100.0

In-service programs

15

93.7

Other music teachers in school

15

93.7

Accessibility of administrator

15

93.7

Fine arts supervisor

Music workshops or conferences

81.2

Administrators' visits to classroom

81.2

Assigned mentor teacher (music)

Administrative assistance with classroom management

10

62.5

Assigned mentor teacher (non-music)

9

56.2

Release time for performances outside of school

Release time to observe experienced

music teachers

Release time to work with feeder school choirs

Release time for recruiting students from other schools

Assistance with administrative duties (fundraising, trips, competitions)

Administrative assistance with budget preparation 
Table 4.82: Methods of professional assistance provided for early career teachers with 2 years of teaching experience $(n=18)$

Method

Frequency

Percentage

In-service programs

18

100.0

Accessibility of administrator

18

100.0

New teacher orientation program

17

94.4

Other music teachers in school

Colleagues in music field

Fine arts supervisor

Other non-music teachers in school

Administrators' visits to classroom

Release time for performances outside of school

Music workshops or conferences

Assigned mentor teacher (non-music)

Administrative assistance with classroom management

Assigned mentor teacher (music)

Release time to observe experienced

music teachers

Release time to work with feeder school choirs

Release time for recruiting students from other schools

Administrative assistance with budget preparation

Assistance with administrative duties (fundraising, trips, competitions) 
Table 4.83: Methods of professional assistance provided for early career teachers with 3 to 3.5 years of teaching experience $(n=20)$

Method

Frequency

Percentage

Colleagues in music field

In-service programs

Other music teachers in school

New teacher orientation program

Fine arts supervisor

Music workshops or conferences

Other non-music teachers in school

Accessibility of administrator

Administrators' visits to classroom

Release time for performances outside of school

Assigned mentor teacher (music)

Release time for recruiting students

from other schools

Release time to work with feeder school choirs

Assigned mentor teacher (non-music)

Release time to observe experienced

music teachers

Administrative assistance with classroom management

Assistance with administrative duties (fundraising, trips, competitions)

Administrative assistance with budget preparation 
Table 4.84: Methods of professional assistance provided for early career teachers with 4 years of teaching experience $(n=13)$

Method

Frequency

Percentage

In-service programs

13

100.0

New teacher orientation program

13

100.0

Other music teachers in school

13

100.0

Fine arts supervisor

12

92.3

Administrators' visits to classroom

12

92.3

Other non-music teachers in school

11

84.6

Music workshops or conferences

11

84.6

Accessibility of administrator

11

84.6

Colleagues in music field

9

69.2

Release time for performances outside of school

Assigned mentor teacher (non-music)

Assigned mentor teacher (music)

Administrative assistance with classroom management

Administrative assistance with budget preparation

Release time to observe experienced

music teachers

Release time to work with feeder school choirs

Administrative assistance with large classes

Release time for recruiting students from other schools

Assistance with administrative duties (fundraising, trips, competitions) 
Table 4.85: Methods of professional assistance provided for early career secondary choir teachers with 5 years of teaching experience $(n=20)$

Method

Frequency

Percentage

In-service programs

20

100.0

Other music teachers in school

20

100.0

Colleagues in music field

20

100.0

Other non-music teachers in school

18

90.0

Music workshops or conferences

18

90.0

Accessibility of administrator

18

90.0

Administrators' visits to classroom

17

85.0

New teacher orientation program

17

85.0

Fine arts supervisor

85.0

Release time for performances outside of school

17

85.0

Release time for recruiting students

from other schools

14

70.0

Administrative assistance with

classroom management

12

60.0

Assigned mentor teacher (non-music)

Assigned mentor teacher (music)

Release time to observe experienced

music teachers

Release time to work with feeder school choirs

Assistance with administrative duties

(fundraising, trips, competitions)

Administrative assistance with budget preparation 


\section{Comparison of Teacher and Principal Perception of Professional Assistance}

Of primary interest was the comparison of early career secondary choral directors and principal responses to the value of various methods of professional assistance.

Several approaches were used to examine the relationship of responses. The mean and standard deviation of the teachers' and principals' ratings of the importance of each method of professional assistance to early career music teachers was calculated (See Table 4.86). The results of the Spearman rank correlation procedure indicated a nonsignificant positive relationship between overall teacher and principal ratings of the value of methods of professional assistance $(\mathrm{rs}=.07, \mathrm{p}=.77)$. The mean teacher response of each of 19 questions was correlated with the mean principal responses over the same 19 questions. This same procedure was used on all subsequent correlations.

Table 4.86: Teacher $(n=87)$ and principal $(n=53)$ rating of importance of methods of professional assistance to early career music teachers $(1=$ no help; $2=$ little help; $3=$ moderately helpful; $4=$ very helpful; $5=$ extremely helpful; $0=$ NA)

Method

\begin{tabular}{crc}
\multicolumn{2}{c}{ Teacher } & \multicolumn{2}{c}{ Principal } \\
Mean SD
\end{tabular}

In service programs

2.7

1.1

3.4

.56

New teacher orientation program

2.8

1.3

3.6

.85

Fine arts supervisor

3.3

1.4

2.8

1.3

Other music teachers in school

3.9

1.2

3.0

.96

Other non-music teachers in school

3.3

.88

3.7

.87

Colleagues in music field

4.2

.77

4.1

.87

Assigned mentor teacher (non-music)

2.3

1.7

3.8

.90

Assigned mentor teacher (music) 
Table 4.86: Continued

Method

\begin{tabular}{ccc}
\multicolumn{2}{c}{ Teacher } & \multicolumn{2}{c}{ Principal } \\
Mean SD & Mean
\end{tabular}

Music workshops or conferences

4.2

.95

3.6

.90

Release time to observe experienced music teachers

2.9

2.1

3.7

.71

Accessibility of administrator

1.1

4.4

Administrators' visits to classroom

2.4

1.0

3.8

Administrative assistance with classroom management

2.7

1.6

4.1

Administrative assistance with budget preparation

1.6

4.0

Assistance with administrative duties (fundraising, trips, competitions)

1.7

3.4

1.0

Administrative assistance with large classes

1.7

1.7

3.6

.98

Release time to work with feeder school choirs 2.0

$1.7 \quad 3.5$

1.3

Release time for performances

outside of school

1.7

3.6

.79

Release time for recruiting students from other schools

Calculations of the mean and standard deviation of the teachers' and principals' ratings of the value of various methods of professional assistance were made for each subgroup. Teachers' and principals' ratings of the value of methods of professional assistance in each of the five Regions are shown in Tables 4.87 to 4.91 . 
Table 4.87: Teachers' $(n=20)$ and principals' $(n=15)$ ratings of importance of methods of professional assistance to early career teachers in Region 3 ( $1=$ no help; $5=$ extremely helpful; $0=$ NA)

Method

\begin{tabular}{lll}
\multicolumn{2}{c}{ Teacher } & \multicolumn{2}{c}{ Principal } \\
Mean SD & Mean SD
\end{tabular}

In-service programs

2.7

New teacher orientation program

3.0

.96

3.3

1.1

Fine arts supervisor

3.7

1.0

3.4

1.1

Other music teachers in school

4.5

1.2

3.8

1.6

Other non-music teachers in school

3.2

.75

3.7

1.2

Colleagues in music field

4.4

.83

3.8

.83

Assigned mentor teacher (non-music)

1.5

.68

4.0

1.1

Assigned mentor teacher (music)

1.6

3.3

1.1

Music workshops or conferences

4.1

2.1

3.4

1.4

Release time to observe experienced

music teachers

3.0

1.2

4.0

.65

Accessibility of administrator

3.9

2.2

4.0

.59

Administrators' visits to classroom

2.8

.94

3.8

1.2

Administrative assistance with

classroom management

3.2

1.5

3.4

1.0

Administrative assistance with

budget preparation

2.2

1.5

3.4

1.1

Assistance with administrative duties

(fundraising, trips, competitions)

2.5

2.1

1.8

3.6

.61

Administrative assistance with large classes

2.0

1.9

3.4

.63

Release time to work with feeder school choirs 2.5

2.0

3.6

.48

Release time for performances

outside of school

3.0

1.8

3.5

1.2

Release time for recruiting students from other schools

1.9

2.1

2.7

1.7 
Table 4.88: Teachers' $(n=27)$ and principals' $(n=14)$ ratings of importance of methods of professional assistance to early career teachers in Region 5 ( $1=$ no help; 5 = extremely helpful; $0=$ NA)

Method

\begin{tabular}{lll}
\multicolumn{2}{c}{ Teacher } & \multicolumn{2}{c}{ Principal } \\
Mean SD Mean & SD
\end{tabular}

In-service programs

2.9

.99

3.8

.77

New teacher orientation program

3.0

1.4

4.0

.82

Fine arts supervisor

3.8

1.0

4.5

.65

Other music teachers in school

4.0

1.1

4.4

.85

Other non-music teachers in school

3.2

1.0

3.7

.72

Colleagues in music field

4.4

.69

4.2

.72

Assigned mentor teacher (non-music)

2.2

1.5

3.9

.82

Assigned mentor teacher (music)

2.8

2.2

4.1

1.3

Music workshops or conferences

4.2

.75

3.8

1.2

Release time to observe experienced

music teachers

3.8

1.7

4.0

.67

Accessibility of administrator

3.7

.90

4.5

.64

Administrators' visits to classroom

2.4

1.0

4.1

.77

Administrative assistance with

classroom management

2.8

1.2

4.0

.82

Administrative assistance with

budget preparation

1.8

1.4

3.7

.72

Assistance with administrative duties

(fundraising, trips, competitions)

2.5

1.5

3.7

.97

Administrative assistance with large classes

1.8

1.4

3.9

.82

Release time to work with feeder school choirs 2.3

1.9

4.0

.73

Release time for performances

outside of school

2.7

1.9

3.9

.73

Release time for recruiting students from other schools

1.8

4.0

1.3 
Table 4.89: Teachers' $(n=6)$ and principals' $(n=3)$ ratings of importance of methods of professional assistance to early career teachers in Region 7 ( $1=$ no help; $5=$ extremely helpful; $0=$ NA)

Method

\begin{tabular}{lll}
\multicolumn{2}{c}{ Teacher } & \multicolumn{2}{c}{ Principal } \\
Mean SD & Mean SD
\end{tabular}

In-service programs

New teacher orientation program

2.5

1.5

3.0

0

Fine arts supervisor

2.8

2.0

3.3

.57

Other music teachers in school

3.1

1.8

1.0

1.0

Other non-music teachers in school

2.8

1.6

1.0

1.0

Colleagues in music field

3.5

1.0

3.6

1.1

4.3

.81

4.0

1.0

Assigned mentor teacher (non-music)

2.3

1.6

4.0

1.0

Assigned mentor teacher (music)

2.3

2.3

3.3

1.1

Music workshops or conferences

4.6

.51

3.3

.57

Release time to observe experienced

music teachers

2.3

2.5

3.3

.57

Accessibility of administrator

Administrators' visits to classroom

2.0

.89

4.0

1.0

Administrative assistance with

classroom management

2.5

1.5

4.3

Administrative assistance with budget preparation

1.8

1.9

4.6

Assistance with administrative duties

(fundraising, trips, competitions)

2.0

2.3

3.0

1.7

Administrative assistance with large classes

1.5

2.0

3.3

1.5

Release time to work with feeder school choirs 2.6

2.2

3.3

Release time for performances

outside of school

3.6

1.9

3.6

.57

Release time for recruiting students from other schools

1.6

2.0

3.3

1.5 
Table 4.90: Teachers' $(n=13)$ and principals' $(n=7)$ ratings of importance of methods of professional assistance to early career teachers in Region 20 ( $1=$ no help; 5 = extremely helpful; $0=$ NA)

\begin{tabular}{|c|c|c|c|c|}
\hline \multirow[t]{2}{*}{ Method } & \multicolumn{2}{|c|}{ Teacher } & \multicolumn{2}{|c|}{ Principal } \\
\hline & Mean & SD & Mean & SD \\
\hline In-service programs & 2.8 & 1.0 & 4.0 & .89 \\
\hline New teacher orientation program & 2.7 & .99 & 4.3 & 1.0 \\
\hline Fine arts supervisor & 2.4 & 1.6 & 3.6 & 1.9 \\
\hline Other music teachers in school & 3.8 & 1.1 & 4.6 & .51 \\
\hline Other non-music teachers in school & 3.7 & .82 & 4.5 & .83 \\
\hline Colleagues in music field & 4.2 & .89 & 4.5 & .54 \\
\hline Assigned mentor teacher (non-music) & 1.8 & 1.6 & 4.6 & .51 \\
\hline Assigned mentor teacher (music) & 3.1 & 2.0 & 4.6 & .51 \\
\hline Music workshops or conferences & 4.2 & .91 & 4.5 & .83 \\
\hline $\begin{array}{l}\text { Release time to observe experienced } \\
\text { music teachers }\end{array}$ & 2.7 & 2.1 & 4.3 & .94 \\
\hline Accessibility of administrator & 3.0 & .73 & 4.6 & .51 \\
\hline Administrators' visits to classroom & 2.6 & 1.0 & 4.3 & .10 \\
\hline $\begin{array}{l}\text { Administrative assistance with } \\
\text { classroom management }\end{array}$ & 2.3 & 1.0 & 4.8 & .40 \\
\hline $\begin{array}{l}\text { Administrative assistance with } \\
\text { budget preparation }\end{array}$ & 1.8 & .91 & 4.3 & .81 \\
\hline $\begin{array}{l}\text { Assistance with administrative duties } \\
\text { (fundraising, trips, competitions) }\end{array}$ & 2.0 & 1.1 & 4.1 & .75 \\
\hline Administrative assistance with large classes & 1.6 & 1.3 & 4.5 & .54 \\
\hline Release time to work with feeder school choirs & 2.1 & 1.7 & 4.3 & .81 \\
\hline $\begin{array}{l}\text { Release time for performances } \\
\text { outside of school }\end{array}$ & 3.0 & 1.6 & 4.3 & .81 \\
\hline
\end{tabular}


Table 4.90: Continued

Method

\begin{tabular}{ll}
\multicolumn{2}{c}{ Teacher Principal } \\
Mean SD Mean
\end{tabular}

Release time for recruiting students from other schools

Table 4.91: Teachers' $(n=21)$ and principals' $(n=14)$ ratings of importance of methods of professional assistance to early career teachers in Region 24 ( 1 = no help; $5=$ extremely helpful; $0=\mathrm{NA}$ )

Method

\begin{tabular}{ll}
\multicolumn{2}{c}{ Teacher } \\
Mean SDincipal
\end{tabular}

SD

In-service programs

New teacher orientation program

Fine arts supervisor

Other music teachers in school

Other non-music teachers in school

Colleagues in music field

Assigned mentor teacher (non-music)

Assigned mentor teacher (music)

Music workshops or conferences

Release time to observe experienced music teachers

Accessibility of administrator

Administrators' visits to classroom

Administrative assistance with classroom management
2.9

2.2

3.3

4.2

3.1

4.1

1.8

3.0

4.1

3.4

4.0

3.0

2.8

1.4

4.0

.47 
Table 4.91: Continued

Method

Teacher

SD Mean SD

Administrative assistance with

budget preparation

2.0

1.7

3.6

.49

Assistance with administrative duties

(fundraising, trips, competitions)

2.7

1.5

3.7

.61

Administrative assistance with large classes

1.8

1.6

3.7

.61

Release time to work with feeder school choirs 2.2

2.0

3.5

.51

Release time for performances

outside of school

1.3

3.2

.72

Release time for recruiting students from other schools

2.6

2.0

3.2

.61

Data analysis by Region revealed that a significant positive relationship existed between teacher and principal ratings in Region 3 and Region 5 (See Table 4.92).

Table 4.92: Correlation of mean teacher/principal responses to value of 19 methods of assistance by Region

\begin{tabular}{ccc}
\hline Region & rs & $\mathrm{p}$ \\
\hline & & \\
3 & .66 & $.0008 *$ \\
5 & .57 & $.005 *$ \\
7 & .04 & .85 \\
20 & .23 & .32 \\
24 & .26 & .26 \\
$*$ Indicates significant positive correlation $\mathrm{p}<.05$ & \\
\hline
\end{tabular}


Tables 4.93 to 4.97 show teachers' and principals' ratings of methods of

assistance in each of the five District categories.

Table 4.93: Teachers' $(n=24)$ and principals' $(n=13)$ ratings of importance of methods of professional assistance to early career teachers in District A schools $(1=$ no help; $5=$ extremely helpful; $0=$ NA)

Method

\begin{tabular}{lll}
\multicolumn{2}{c}{ Teacher } & \multicolumn{2}{c}{ Principal } \\
Mean SD & Mean SD
\end{tabular}

In-service programs

2.9

.99

3.6

.75

New teacher orientation program

3.1

1.1

4.0

.70

Fine arts supervisor

4.2

.90

4.6

.48

Other music teachers in school

4.0

1.2

4.2

.83

Other non-music teachers in school

3.0

1.0

3.6

.63

Colleagues in music field

4.3

.55

4.3

.48

Assigned mentor teacher (non-music)

1.6

1.4

3.8

.80

Assigned mentor teacher (music)

Music workshops or conferences

4.2

.79

4.3

.48

Release time to observe experienced

music teachers

3.3

2.1

4.1

.55

Accessibility of administrator

Administrators' visits to classroom

Administrative assistance with classroom management

Administrative assistance with budget preparation

Assistance with administrative duties (fundraising, trips, competitions)

Administrative assistance with large classes 
Table 4.93: Continued

Method

\begin{tabular}{lll}
\multicolumn{2}{c}{ Teacher } & \multicolumn{2}{c}{ Principal } \\
Mean SD & Mean
\end{tabular}

Release time for performances

outside of school

2.7

1.8

3.8

.80

Release time for recruiting

students from other schools

2.

1.6

3.5

1.5

Table 4.94: Teachers' $(n=21)$ and principals' $(n=12)$ ratings of importance of methods of professional assistance to early career teachers in District B schools $(1=$ no help; 5 = extremely helpful; $0=$ NA)

Method

\begin{tabular}{lll}
\multicolumn{2}{c}{ Teacher } & \multicolumn{2}{c}{ Principal } \\
Mean SD Mean & SD
\end{tabular}

In-service programs

3.0

.58

3.4

1.1

New teacher orientation program

2.7

.94

3.8

1.4

Fine arts supervisor

3.9

.83

3.9

1.3

Other music teachers in school

4.3

1.1

4.0

1.4

Other non-music teachers in school

3.1

1.0

3.7

.86

Colleagues in music field

4.4

.67

3.7

1.2

Assigned mentor teacher (non-music)

2.3

1.7

3.2

1.2

Assigned mentor teacher (music)

3.1

2.1

3.3

2.1

Music workshops or conferences

4.0

1.2

3.7

1.4

Release time to observe experienced music teachers

Accessibility of administrator

Administrators' visits to classroom

Administrative assistance with classroom management 
Table 4.94: Continued

Method

\begin{tabular}{lll}
\multicolumn{2}{c}{ Teacher } & \multicolumn{2}{c}{ Principal } \\
Mean SD & Mean
\end{tabular}

Administrative assistance with

budget preparation

2.3

1.7

3.0

1.7

Assistance with administrative duties

(fundraising, trips, competitions)

2.8

1.6

3.0

1.5

Administrative assistance with large classes

2.1

1.6

2.5

1.3

Release time to work with feeder school choirs 2.9

1.9

2.9

1.8

Release time for performances

outside of school

3.7

1.4

4.0

.85

Release time for recruiting students from other schools

3.

2.0

3.2

1.9

Table 4.95: Teacher $(n=25)$ and principal $(n=17)$ rating of importance of methods of professional assistance to early career teachers in District $\mathrm{C}$ schools $(1=$ no help; 5 = extremely helpful; $0=\mathrm{NA}$ )

Method

\begin{tabular}{lll}
\multicolumn{2}{c}{ Teacher } & \multicolumn{2}{c}{ Principal } \\
Mean SD Mean
\end{tabular}

In-service programs

2.7

1.2

3.7

.90

New teacher orientation program

2.6

1.4

4.1

.78

Fine arts supervisor

3.2

1.2

4.2

.75

Other music teachers in school

4.3

.74

4.3

.78

Other non-music teachers in school

3.3

.81

3.8

.92

Colleagues in music field

4.

Assigned mentor teacher (non-music)

2.4

.92

4.4

.71

Assigned mentor teacher (music)

3.3

1.5

3.8

.85

Music workshops or conferences

4.1

1.9

3.6

1.4

.89

3.8

1.1 
Table 4.95: Continued

Method

\begin{tabular}{lll}
\multicolumn{2}{c}{ Teacher } & \multicolumn{2}{c}{ Principal } \\
Mean SD & Mean
\end{tabular}

Release time to observe experienced

music teachers

$\begin{array}{llll}3.6 & 1.7 & 3.9 & .74 \\ 3.7 & .83 & 4.4 & .79 \\ 2.7 & 1.0 & 3.8 & .69 \\ 2.8 & 1.3 & 4.0 & .70\end{array}$

Accessibility of administrator

Administrators' visits to classroom

$\begin{array}{llll}2.1 & 1.6 & 3.5 & .61\end{array}$

budget preparation

Assistance with administrative duties

(fundraising, trips, competitions)

2.6

1.6

3.5

.93

Administrative assistance with large classes

2.2

1.7

3.8

.72

Release time to work with feeder school choirs 2.5

2.0

3.9

.82

Release time for performances

outside of school

3.5

1.3

3.9

.82

Release time for recruiting

students from other schools

2.3

1.9

3.8

1.2

Table 4.96: Teachers' $(n=10)$ and principals' $(n=7)$ ratings of importance of methods of professional assistance to early career teachers in District D schools $(1=$ no help; 5 = extremely helpful; $0=$ NA)

Method

\begin{tabular}{ll}
\multicolumn{2}{c}{ Teacher } \\
Mean SD
\end{tabular} Mean SD

In-service programs

2.5

1.1

3.2

.48

New teacher orientation program

2.3

1.6

3.2

.95

Fine arts supervisor

1.6

1.7

1.7

2.2 
Table 4.96: Continued

\begin{tabular}{|c|c|c|c|c|}
\hline \multirow[t]{2}{*}{ Method } & \multicolumn{2}{|c|}{ Teacher } & \multicolumn{2}{|c|}{ Principal } \\
\hline & Mean & $\mathrm{SD}$ & Mean & $\mathrm{SD}$ \\
\hline Other music teachers in school & 3.4 & 1.1 & 3.5 & 1.6 \\
\hline Other non-music teachers in school & 3.3 & .94 & 3.7 & .75 \\
\hline Colleagues in music field & 4.6 & .51 & 4.1 & .37 \\
\hline Assigned mentor teacher (non-music) & 1.7 & 1.8 & 3.7 & .95 \\
\hline Assigned mentor teacher (music) & 2.1 & 2.1 & 4.0 & .57 \\
\hline Music workshops or conferences & 4.7 & 67 & 3.8 & .69 \\
\hline $\begin{array}{l}\text { Release time to observe experienced } \\
\text { music teachers }\end{array}$ & 2.4 & 2.4 & 3.2 & 1.6 \\
\hline Accessibility of administrator & 3.6 & 69 & 4.2 & .48 \\
\hline Administrators' visits to classroom & 2.3 & .94 & 3.5 & .78 \\
\hline $\begin{array}{l}\text { Administrative assistance with } \\
\text { classroom management }\end{array}$ & 2.4 & 1.3 & 4.0 & .81 \\
\hline $\begin{array}{l}\text { Administrative assistance with } \\
\text { budget preparation }\end{array}$ & 2.1 & 1.3 & 3.8 & .37 \\
\hline $\begin{array}{l}\text { Assistance with administrative duties } \\
\text { (fundraising, trips, competitions) }\end{array}$ & 1.6 & 1.6 & 3.5 & .53 \\
\hline Administrative assistance with large classes & 1.0 & 1.5 & 4.0 & .57 \\
\hline Release time to work with feeder school choirs & 2.4 & 2.3 & 4.0 & .81 \\
\hline $\begin{array}{l}\text { Release time for performances } \\
\text { outside of school }\end{array}$ & 3.8 & 1.0 & 3.8 & .89 \\
\hline $\begin{array}{l}\text { Release time for recruiting } \\
\text { students from other schools }\end{array}$ & 2.2 & 2.2 & 3.0 & 1.5 \\
\hline
\end{tabular}


Table 4.97: Teachers' $(n=7)$ and principals' $(n=4)$ ratings of importance of methods of professional assistance to early career teachers in District $\mathrm{E}-\mathrm{I}$ schools $(1=$ no help; 5 = extremely helpful; $0=\mathrm{NA}$ )

Method

\begin{tabular}{lll}
\multicolumn{2}{c}{ Teacher } & \multicolumn{2}{c}{ Principal } \\
Mean SD & Mean SD
\end{tabular}

In-service programs

2.7

1.3

3.0

0

New teacher orientation program

2.8

1.5

3.3

.57

Fine arts supervisor

3.1

1.4

1.0

1.0

Other music teachers in school

3.1

1.6

1.0

1.0

Other non-music teachers in school

3.7

.95

3.6

1.1

Colleagues in music field

4.2

.75

4.0

1.0

Assigned mentor teacher (non-music)

2.2

1.7

4.0

1.0

Assigned mentor teacher (music)

1.7

2.2

3.3

1.1

Music workshops or conferences

4.7

.48

3.3

.57

Release time to observe experienced

music teachers

3.0

2.0

3.3

.57

Accessibility of administrator

3.4

1.2

5.0

0

Administrators' visits to classroom

2.2

1.3

4.0

1.0

Administrative assistance with

classroom management

3.1

1.3

4.3

.57

Administrative assistance with budget preparation

1.4

1.8

4.6

Assistance with administrative duties

(fundraising, trips, competitions)

2.5

2.3

3.0

1.7

Administrative assistance with large classes

2.4

2.1

3.3

1.5

Release time to work with feeder school choirs 1.5

1.5

3.3

Release time for performances

outside of school

3.0

2.1

3.6

.57

Release time for recruiting students from other schools

1.1

1.4

3.3

1.5 
A comparison of teachers' and principals' ratings in accordance with the size of school district indicated that a strong positive correlation existed in District A, District B, and District C schools (See Table 4.98).

Table 4.98: Correlation of mean teacher/principal responses to value of 19 methods of assistance by District

\begin{tabular}{lcc} 
District & rs & $\mathrm{p}$ \\
\hline $\mathrm{A}$ & .64 & $.002 *$ \\
$\mathrm{~B}$ & .69 & $.0004 *$ \\
$\mathrm{C}$ & .54 & $.01 *$ \\
$\mathrm{D}$ & .29 & .21 \\
$\mathrm{E}-\mathrm{I}$ & .02 & .91 \\
* Indicates significant positive correlation $\mathrm{p}<.05$ & \\
& & \\
\hline
\end{tabular}

Principals' and teachers' ratings of the value of methods of professional assistance of various School Types is indicated in Tables 4.99 to 4.101 .

Table 4.99: Teachers' $(n=5)$ and principals' $(n=3)$ ratings of importance of methods of professional assistance to early career teachers in rural schools $(1=$ no help; $5=$ extremely helpful; $0=$ NA)

Method

\begin{tabular}{lll}
\multicolumn{2}{c}{ Teacher } & \multicolumn{2}{c}{ Principal } \\
Mean SD & Mean
\end{tabular}

In-service programs

2.6

1.5

3.0

0

New teacher orientation program

2.8

1.7

3.3

.57

Fine arts supervisor

3.2

1.7

1.0

1.0

Other music teachers in school

3.6

1.6

1.0

1.0 
Table 4.99: Continued

Method

Teacher

SD Mean SD

Other non-music teachers in school

3.8

.83

3.6

1.1

Colleagues in music field

4.2

.83

4.0

1.0

Assigned mentor teacher (non-music)

3.0

2.0

4.0

1.0

Assigned mentor teacher (music)

3.2

2.4

3.3

1.1

Music workshops or conferences

4.4

.89

3.3

.57

Release time to observe experienced

music teachers

2.6

2.4

3.3

.57

Accessibility of administrator

3.2

1.4

5.0

0

Administrators' visits to classroom

2.2

.83

4.0

1.0

Administrative assistance with

classroom management

2.6

2.3

4.3

.57

Administrative assistance with

budget preparation

1.8

2.0

4.6

.57

Assistance with administrative duties (fundraising, trips, competitions)

2.6

2.5

3.0

1.7

Administrative assistance with large classes

1.8

2.1

3.3

1.5

Release time to work with feeder school choirs 1.6

1.5

3.3

2.0

Release time for performances

outside of school

3.6

2.0

3.6

.57

Release time for recruiting

students from other schools

1.6

1.5

3.3

1.5 
Table 4.100: Teachers' $(n=57)$ and principals' $(n=34)$ ratings of importance of methods of professional assistance to early career teachers in suburban schools ( $1=$ no help; $5=$ extremely helpful; $0=$ NA)

Method

\begin{tabular}{crr}
\multicolumn{2}{c}{ Teacher } & \multicolumn{2}{c}{ Principal } \\
Mean SD
\end{tabular}

In-service programs

2.8

1.0

3.5

.92

New teacher orientation program

2.9

1.3

3.9

.98

Fine arts supervisor

3.5

1.4

3.9

1.4

Other music teachers in school

4.0

1.2

4.0

1.2

Other non-music teachers in school

3.2

1.0

3.7

.82

Colleagues in music field

4.4

.67

4.2

.97

Assigned mentor teacher (non-music)

1.9

1.7

3.5

1.0

Assigned mentor teacher (music)

Music workshops or conferences

Release time to observe experienced music teachers

Accessibility of administrator

Administrators' visits to classroom

Administrative assistance with

classroom management

Administrative assistance with budget preparation

Assistance with administrative duties

(fundraising, trips, competitions)

Administrative assistance with large classes

Release time for performances

outside of school

Release time for recruiting students from other schools 
Table 4.101: Teachers' $(n=25)$ and principals' $(n=16)$ ratings of importance of methods of professional assistance to early career teachers in urban schools $(1=$ no help; 5 = extremely helpful; $0=$ NA)

Method

\begin{tabular}{crrr}
\multicolumn{2}{c}{ Teacher } & \multicolumn{2}{c}{ Principal } \\
Mean SD & Mean
\end{tabular}

In-service programs

2.7

.84

3.7

.77

New teacher orientation program

2.7

1.1

3.8

1.0

Fine arts supervisor

3.4

1.2

3.6

1.7

Other music teachers in school

4.2

.91

4.2

.68

Other non-music teachers in school

3.1

.83

3.8

.71

Colleagues in music field

4.2

.81

4.1

.65

Assigned mentor teacher (non-music)

2.2

1.5

4.1

.71

Assigned mentor teacher (music)

3.2

1.8

4.3

Music workshops or conferences

3.9

1.2

3.8

Release time to observe experienced music teachers

3.2

1.9

4.1

.61

Accessibility of administrator

Administrators' visits to classroom

2.3

1.2

4.0

Administrative assistance with

classroom management

2.4

1.5

4.3

Administrative assistance with budget preparation

Assistance with administrative duties

(fundraising, trips, competitions)

Administrative assistance with large classes

1.2

1.4

3.9

Release time to work with feeder school choirs 1.8

1.7

3.8

Release time for performances

outside of school

1.9

3.6

.80

Release time for recruiting students from other schools 
When subjects were divided into School Types, the data showed a significant positive correlation between mean responses of teachers and principals in suburban schools. A negative, non-significant correlation existed between ratings of teachers and principals in rural schools (See Table 4.102).

Table 4.102: Correlation of mean teacher/principal responses to value of 19 methods of assistance by School Type

Type

Rural

Suburban

Urban rs

$-.005$

.69

.38 $\mathrm{p}$

$.98 * *$

$.001 *$

.10

* Indicates significant positive correlation $\mathrm{p}<.05$

** Indicates non-significant negative correlation $\mathrm{p}<.05$

A list of the teachers' and principals' ratings of the value of methods of professional assistance by School Level appears in Tables 4.103 - 4.105.

Table 4.103: Teachers' $(n=26)$ and principals' $(n=18)$ ratings of importance of methods of professional assistance to early career teachers in high schools $(1=$ no help; 5 = extremely helpful; $0=$ NA)

Method

\begin{tabular}{lll}
\multicolumn{2}{c}{ Teacher } & \multicolumn{2}{c}{ Principal } \\
Mean SD & Mean SD
\end{tabular}

In-service programs 2.5

1.1

3.4

1.2

New teacher orientation program

2.3

1.1

3.6

1.2

Fine arts supervisor

3.4

1.4

3.5

1.8 
Table 4.103: Continued

Method

\begin{tabular}{lll}
\multicolumn{2}{c}{ Teacher } & \multicolumn{2}{c}{ Principal } \\
Mean SD & Mean SD
\end{tabular}

Other music teachers in school

4.0

1.0

4.1

1.4

Other non-music teachers in school

3.0

.84

3.6

.97

Colleagues in music field

4.1

.76

3.8

1.1

Assigned mentor teacher (non-music)

1.5

1.3

3.6

1.2

Assigned mentor teacher (music)

3.1

1.8

4.1

1.1

Music workshops or conferences

4.1

.78

3.7

1.5

Release time to observe experienced

music teachers

3.3

1.9

4.1

.70

Accessibility of administrator

3.7

.77

4.1

1.2

Administrators' visits to classroom

2.5

1.0

3.7

1.1

Administrative assistance with

classroom management

2.4

1.5

4.0

1.1

Administrative assistance with budget preparation

1.9

1.5

3.8

.78

Assistance with administrative duties

(fundraising, trips, competitions)

2.2

1.7

3.7

.80

Administrative assistance with large classes

1.5

1.4

3.9

.72

Release time to work with feeder school choirs 3.0

1.8

4.1

1.2

Release time for performances

outside of school

3.6

1.5

3.7

1.2

Release time for recruiting students from other schools

2.5

1.7

3.5

1.7 
Table 4.104: Teachers' $(n=19)$ and principals' $(n=8)$ ratings of importance of methods of professional assistance to early career teachers in junior high schools $(1=$ no help; $5=$ extremely helpful; $0=$ NA)

Method

\begin{tabular}{crr}
\multicolumn{2}{c}{ Teacher } & \multicolumn{2}{c}{ Principal } \\
Mean SD Mean
\end{tabular}

In-service programs

3.

New teacher orientation program

3.4

1.1

3.6

.51

Fine arts supervisor

3.6

1.0

3.8

.64

Other music teachers in school

3.9

1.0

3.8

1.7

Other non-music teachers in school

3.1

1.4

3.8

1.6

Colleagues in music field

4.6

1.0

3.6

.51

Assigned mentor teacher (non-music)

2.1

.49

4.3

Assigned mentor teacher (music)

1.8

1.6

3.6

.74

Music workshops or conferences

4.2

2.3

3.7

1.5

Release time to observe experienced

music teachers

3.8

Accessibility of administrator

3.7

.78

4.0

.75

Administrators' visits to classroom

2.3

1.8

3.8

.64

Administrative assistance with

classroom management

3.3

.80

4.6

Administrative assistance with budget preparation

1.8

.95

4.1

Assistance with administrative duties

(fundraising, trips, competitions)

2.5

1.7

1.3

4.1

.83

Administrative assistance with large classes

2.2

1.6

3.6

1.3

Release time to work with feeder school choirs 2.4

1.9

3.7

1.1

Release time for performances

outside of school

1.8

3.8

.64

Release time for recruiting students from other schools 
Teacher 4.105: Teachers' $(n=42)$ and principals' $(n=27)$ ratings of importance of methods of professional assistance to early career teachers in middle schools $(1=$ no help; $5=$ extremely helpful; $0=$ NA)

Method

\begin{tabular}{crrr}
\multicolumn{2}{c}{ Teacher } & \multicolumn{2}{c}{ Principal } \\
Mean SD Mean SD
\end{tabular}

In-service programs

2.8

.89

3.5

.64

New teacher orientation program

2.7

1.3

4.0

.83

Fine arts supervisor

3.4

1.5

3.7

1.4

Other music teachers in school

4.0

1.1

3.8

1.1

Other non-music teachers in school

3.4

.94

3.8

.75

Colleagues in music field

4.3

.75

4.2

Assigned mentor teacher (non-music)

2.4

1.7

3.8

.78

Assigned mentor teacher (music)

3.3

1.9

3.8

1.0

Music workshops or conferences

4.2

1.1

3.8

.57

Release time to observe experienced

music teachers

2.9

2.1

3.8

1.0

Accessibility of administrator

3.7

1.0

4.1

.73

Administrators' visits to classroom

2.8

1.2

3.7

.60

Administrative assistance with

classroom management

2.7

1.2

3.9

.67

Administrative assistance with budget preparation

2.0

1.5

3.6

Assistance with administrative duties

(fundraising, trips, competitions)

2.5

1.6

3.5

.63

Administrative assistance with large classes

1.9

1.6

3.7

.66

Release time to work with feeder school choirs 1.9

1.9

3.3

.88

Release time for performances

outside of school

3.3

1.5

3.5

.75

Release time for recruiting students from other schools

2.2

2.1

3.3

.96 
An examination of subjects in terms of School Level revealed a significant

positive correlation between mean responses of teachers and principals in junior high and middle schools (See Table 4.106).

Table 4.106: Correlation of mean teacher/principal responses to value of 19 methods of assistance by School Level

Level

High School

Junior High School

Middle School

* Indicates significant positive correlation $\mathrm{p}<.05$
.26

.44

.56

rS

$\mathrm{p}$

.26

$.05 *$

$.01 *$

Teachers' and principals' ratings of the importance of methods of professional assistance for the five categories of Conferences are shown in Tables 4.107 to 4.111.

Table 4.107: Teachers' $(n=13)$ and principals' $(n=8)$ ratings of importance of methods of professional assistance to early career teachers in Conference AA to AAAA schools $(1=$ no help; $5=$ extremely helpful; $0=$ NA $)$

Method

\begin{tabular}{lll}
\multicolumn{2}{c}{ Teacher } & \multicolumn{2}{c}{ Principal } \\
Mean SD Mean
\end{tabular}

In-service programs

2.4

1.3

3.2

.95

New teacher orientation program

2.4

1.5

3.5

.97

Fine arts supervisor

3.1

1.5

2.5

2.1

Other music teachers in school

3.6

1.3

3.8

1.3

Other non-music teachers in school

3.0

1.1

3.4

.78

Colleagues in music field

4.3

.75

2.1

.69 
Table 4.107: Continued

\begin{tabular}{|c|c|c|c|c|}
\hline \multirow[t]{2}{*}{ Method } & \multicolumn{2}{|c|}{ Teacher } & \multicolumn{2}{|c|}{ Principal } \\
\hline & Mean & $\mathrm{SD}$ & Mean & $\mathrm{SD}$ \\
\hline Assigned mentor teacher (non-music) & 1.4 & 1.3 & 3.4 & .78 \\
\hline Assigned mentor teacher (music) & 3.0 & 1.9 & 4.0 & .57 \\
\hline Music workshops or conferences & 4.2 & .83 & 4.0 & .81 \\
\hline $\begin{array}{l}\text { Release time to observe experienced } \\
\text { music teachers }\end{array}$ & 3.7 & 1.6 & 4.0 & .57 \\
\hline Accessibility of administrator & 3.7 & .83 & 4.1 & .89 \\
\hline Administrators' visits to classroom & 2.4 & 1.1 & 3.8 & .69 \\
\hline $\begin{array}{l}\text { Administrative assistance with } \\
\text { classroom management }\end{array}$ & 2.3 & 1.4 & 4.0 & .57 \\
\hline $\begin{array}{l}\text { Administrative assistance with } \\
\text { budget preparation }\end{array}$ & 2.0 & 1.7 & 4.0 & .81 \\
\hline $\begin{array}{l}\text { Assistance with administrative duties } \\
\text { (fundraising, trips, competitions) }\end{array}$ & 2.3 & 1.8 & 3.8 & .89 \\
\hline Administrative assistance with large classes & 1.4 & 1.6 & 3.7 & .75 \\
\hline Release time to work with feeder school choirs & 2.6 & 1.9 & 4.5 & .53 \\
\hline $\begin{array}{l}\text { Release time for performances } \\
\text { outside of school }\end{array}$ & 3.6 & 1.2 & 4.1 & .89 \\
\hline $\begin{array}{l}\text { Release time for recruiting } \\
\text { students from other schools }\end{array}$ & 2.3 & 1.6 & 3.1 & 2.0 \\
\hline
\end{tabular}


Table 4.108: Teachers' $(\mathrm{n}=13)$ and principals' $(\mathrm{n}=11)$ ratings of importance of methods of professional assistance to early career teachers in Conference AAAAA schools $(1=$ no help; $5=$ extremely helpful; $0=$ NA $)$

Method

\begin{tabular}{lll}
\multicolumn{2}{c}{ Teacher } & \multicolumn{2}{c}{ Principal } \\
Mean SD
\end{tabular}

In-service programs

2.4

New teacher orientation program

2.4

1.3

3.2

.95

Fine arts supervisor

2.4

1.5

3.5

.97

Other music teachers in school

3.1

1.5

2.5

2.1

3.6

1.3

3.8

1.3

Other non-music teachers in school

3.0

1.1

3.4

.78

Colleagues in music field

4.3

.75

2.1

.69

Assigned mentor teacher (non-music)

1.4

1.3

3.4

.78

Assigned mentor teacher (music)

Music workshops or conferences

4.2

.83

4.0

Release time to observe experienced music teachers

Accessibility of administrator

Administrators' visits to classroom

Administrative assistance with

classroom management

2.3

1.4

4.0

Administrative assistance with budget preparation

2.0

1.7

4.0

Assistance with administrative duties

(fundraising, trips, competitions)

\section{3}

1.8

3.8

.89

Administrative assistance with large classes

1.4

1.6

3.7

.75

Release time to work with feeder school choirs 2.6

1.9

4.5

Release time for performances

outside of school

3.6

1.2

4.1

.89

Release time for recruiting students from other schools 
Table 4.109: Teachers' $(n=6)$ and principals' $(n=3)$ ratings of importance of methods of professional assistance to early career teachers in Conference BB and BBB schools $(1=$ no help; $5=$ extremely helpful; $0=\mathrm{NA})$

Method

\begin{tabular}{ccc}
\multicolumn{2}{c}{ Teacher } & \multicolumn{2}{c}{ Principal } \\
Mean SD Mean
\end{tabular}

In-service programs

3.

New teacher orientation program

3.5

1.0

3.6

.57

Fine arts supervisor

3.0

.83

3.6

.57

Other music teachers in school

4.1

.63

4.3

1.1

Other non-music teachers in school

3.3

1.1

4.3

.57

Colleagues in music field

4.8

.51

3.6

Assigned mentor teacher (non-music)

3.0

.40

4.3

Assigned mentor teacher (music)

1.6

1.7

3.3

.57

Music workshops or conferences

4.1

2.5

2.6

2.3

Release time to observe experienced

music teachers

5.0

.75

3.6

Accessibility of administrator

Administrators' visits to classroom

Administrative assistance with

classroom management

Administrative assistance with budget preparation

Assistance with administrative duties

(fundraising, trips, competitions)

\section{3}

2.2

3.3

1.5

Administrative assistance with large classes

1.6

2.2

3.6

1.1

Release time to work with feeder school choirs 3.3

2.2

3.3

.57

Release time for performances

outside of school

1.8

3.3

.57

Release time for recruiting students from other schools 
Table 4.110: Teachers' $(n=26)$ and principals' $(n=16)$ ratings of importance of methods of professional assistance to early career teachers in Conference $\mathrm{CC}$ schools ( $1=$ no help; 5 = extremely helpful; $0=\mathrm{NA})$

Method

\begin{tabular}{crr}
\multicolumn{2}{c}{ Teacher } & \multicolumn{2}{c}{ Principal } \\
Mean SD
\end{tabular}

In-service programs

2.5

New teacher orientation program

2.5

.75

3.6

.70

Fine arts supervisor

3.2

1.3

4.0

.85

Other music teachers in school

3.8

1.3

3.5

1.5

Other non-music teachers in school

3.2

1.4

3.5

1.6

Colleagues in music field

4.2

.95

3.8

.75

Assigned mentor teacher (non-music)

2.0

.81

4.3

.60

Assigned mentor teacher (music)

2.9

1.6

3.9

.85

Music workshops or conferences

4.2

2.1

3.6

1.2

Release time to observe experienced

music teachers

3.3

1.2

3.9

.68

Accessibility of administrator

Administrators' visits to classroom

Administrative assistance with

classroom management

2.7

1.1

3.7

Administrative assistance with budget preparation

1.6

1.1

3.9

Assistance with administrative duties

(fundraising, trips, competitions)

1.5

3.8

Administrative assistance with large classes

1.8

1.6

3.5

Release time to work with feeder school choirs 1.5

1.6

3.6

Release time for performances

outside of school

1.7

3.5

Release time for recruiting students from other schools 
Table 4.111: Teachers' $(n=29)$ and principals' $(n=15)$ ratings of importance of methods of professional assistance to early career teachers in Conference CCC schools $(1=$ no help; $5=$ extremely helpful; $0=$ NA)

Method

\begin{tabular}{lll}
\multicolumn{2}{c}{ Teacher } & \multicolumn{2}{c}{ Principal } \\
Mean SD Mean SD
\end{tabular}

In-service programs

3.0

.99

3.5

.51

New teacher orientation program

3.2

1.2

4.0

.75

Fine arts supervisor

3.8

1.3

4.1

1.3

Other music teachers in school

4.2

.94

4.1

.74

Other non-music teachers in school

Colleagues in music field

Assigned mentor teacher (non-music)

2.4

1.8

3.6

Assigned mentor teacher (music)

Music workshops or conferences

Release time to observe experienced music teachers

Accessibility of administrator

Administrators' visits to classroom

Administrative assistance with

classroom management

Administrative assistance with budget preparation

Assistance with administrative duties

(fundraising, trips, competitions)

Administrative assistance with large classes

Release time to work with feeder school choirs 2.2

1.9

3.6

Release time for performances

outside of school

Release time for recruiting students from other schools 
Comparing subjects in accordance with School Conference indicated that a

significant positive correlation between teachers' and principals' ratings only existed in Conference CCC schools (See Table 4.112).

Table 4.112: Correlation of mean teacher/principal responses to value of 19 methods of assistance by Conference

\begin{tabular}{lll} 
Conference & rs & $\mathrm{p}$ \\
\hline
\end{tabular}

$\begin{array}{lcc}\text { AA - AAAA } & .16 & .48 \\ \text { AAAAA } & .16 & .48 \\ \text { BB - BBB } & .34 & .15 \\ \text { CC } & .32 & .17 \\ \text { CCC } & .66 & .001 * \\ * \text { Indicates significant positive correlation } \mathrm{p}<.05 & \\ \end{array}$

Tables 4.113 to 4.417 provide teachers' and principals' ratings of importance of methods of professional assistance in accordance with Years of Teaching Experience. 
Table 4.113: Teachers' $(n=16)$ and principals' $(n=10)$ ratings of importance of methods of professional assistance to early career teachers with 1 to 1.5 years of teaching experience $(1=$ no help; $5=$ extremely helpful; $0=\mathrm{NA})$

Method

\begin{tabular}{lll}
\multicolumn{2}{c}{ Teacher } & \multicolumn{2}{c}{ Principal } \\
Mean SD Mean
\end{tabular}

In-service programs

2.6

New teacher orientation program

2.7

.94

3.6

.51

Fine arts supervisor

3.8

.77

3.7

.67

Other music teachers in school

4.3

.91

3.5

1.7

Other non-music teachers in school

3.4

1.0

3.9

.56

Colleagues in music field

4.3

.81

3.8

.42

Assigned mentor teacher (non-music)

2.0

.71

4.0

Assigned mentor teacher (music)

2.8

1.4

3.6

.51

Music workshops or conferences

3.9

2.1

4.0

.47

Release time to observe experienced

music teachers

2.5

1.3

3.8

Accessibility of administrator

Administrators' visits to classroom

Administrative assistance with

classroom management

Administrative assistance with budget preparation

1.8

1.5

3.7

Assistance with administrative duties

(fundraising, trips, competitions)

3.0

1.9

3.5

.52

Administrative assistance with large classes

1.8

1.8

3.5

.70

Release time to work with feeder school choirs 2.1

1.9

3.4

.84

Release time for performances

outside of school

2.8

1.8

3.3

.82

Release time for recruiting students from other schools 
Table 4.114: Teachers' $(n=18)$ and principals' $(n=10)$ ratings of importance of methods of professional assistance to early career music teachers in second year of teaching ( $1=$ no help; $5=$ extremely helpful; $0=\mathrm{NA}$ )

Method

\begin{tabular}{ccc}
\multicolumn{2}{c}{ Teacher } & \multicolumn{2}{c}{ Principal } \\
Mean SD & Mean SD
\end{tabular}

In-service programs

2.8

1.0

3.6

.69

New teacher orientation program

2.9

1.1

4.1

.73

Fine arts supervisor

3.4

1.3

3.7

2.0

Other music teachers in school

4.2

.87

4.2

1.5

Other non-music teachers in school

2.9

1.0

3.6

.96

Colleagues in music field

4.1

.85

4.2

Assigned mentor teacher (non-music)

2.1

2.2

4.1

Assigned mentor teacher (music)

Music workshops or conferences

4.1

.78

3.8

Release time to observe experienced music teachers

Accessibility of administrator

Administrators' visits to classroom

Administrative assistance with

classroom management

2.7

1.4

4.4

Administrative assistance with budget preparation

Assistance with administrative duties

(fundraising, trips, competitions)

\section{1}

1.7

3.3

.82

Administrative assistance with large classes

1.7

1.6

3.8

.78

Release time to work with feeder school choirs 2.6

2.0

4.1

.56

Release time for performances

outside of school

3.6

1.7

4.0

.66

Release time for recruiting students from other schools 
Table 4.115: Teachers' $(n=20)$ and principals' $(n=11)$ ratings of importance of methods of professional assistance to early career teachers in third year of teaching $(1=$ no help; 5 = extremely helpful; $0=\mathrm{NA})$

Method

\begin{tabular}{lll}
\multicolumn{2}{c}{ Teacher } & \multicolumn{2}{c}{ Principal } \\
Mean SD & Mean SD
\end{tabular}

In-service programs

2.8

New teacher orientation program

2.8

.93

3.7

.81

Fine arts supervisor

2.6

1.2

4.0

.94

Other music teachers in school

3.4

1.7

4.0

1.4

Other non-music teachers in school

3.8

1.2

3.7

1.9

3.4

.99

3.6

.92

Colleagues in music field

4.2

.76

4.2

.78

Assigned mentor teacher (non-music)

2.1

1.2

3.8

.98

Assigned mentor teacher (music)

4.1

1.2

4.1

.75

Music workshops or conferences

4.2

.89

3.7

1.4

Release time to observe experienced

music teachers

3.6

1.9

3.8

1.4

Accessibility of administrator

3.7

1.0

4.0

.83

Administrators' visits to classroom

2.6

1.1

3.7

.64

Administrative assistance with

classroom management

2.8

.93

3.8

.87

Administrative assistance with budget preparation

2.1

1.2

3.5

.68

Assistance with administrative duties

(fundraising, trips, competitions)

2.2

1.5

3.6

.92

Administrative assistance with large classes

1.7

1.4

3.7

.90

Release time to work with feeder school choirs 2.3

1.9

3.7

1.1

Release time for performances

outside of school

3.2

1.6

3.6

.80

Release time for recruiting students from other schools

1.9


Table 4.116: Teachers' $(n=13)$ and principals' $(n=7)$ ratings of importance of methods of professional assistance to early career teachers with 4 years of teaching experience $(1=$ no help; $5=$ extremely helpful; $0=\mathrm{NA}$ )

Method

\begin{tabular}{lll}
\multicolumn{2}{c}{ Teacher } & \multicolumn{2}{c}{ Principal } \\
Mean SD Mean SD
\end{tabular}

In-service programs

2.3

New teacher orientation program

2.1

1.0

4.1

69

Fine arts supervisor

2.6

1.6

4.2

.95

Other music teachers in school

3.8

1.1

4.0

1.0

Other non-music teachers in school

3.3

1.5

4.0

1.0

Colleagues in music field

4.4

.85

4.5

.53

Assigned mentor teacher (non-music)

2.1

.66

4.5

Assigned mentor teacher (music)

2.3

1.2

4.4

.78

Music workshops or conferences

4.4

2.0

3.5

1.9

Release time to observe experienced

music teachers

2.9

.77

4.0

.81

Accessibility of administrator

3.4

2.1

4.1

69

Administrators' visits to classroom

2.1

1.1

4.7

.48

Administrative assistance with

classroom management

2.1

1.2

4.2

Administrative assistance with budget preparation

1.6

1.0

4.2

Assistance with administrative duties

(fundraising, trips, competitions)

2.1

1.5

1.5

4.0

Administrative assistance with large classes

1.7

1.5

3.7

.95

Release time to work with feeder school choirs 1.6

1.9

4.1

.69

Release time for performances

outside of school

2.8

1.5

3.8

.69

Release time for recruiting students from other schools

1.8

1.8

3.8

.89 
Table 4.117: Teachers' $(n=20)$ and principals' $(n=15)$ ratings of importance of methods of professional assistance to early career teachers in their fifth year of teaching ( $1=$ no help; $5=$ extremely helpful; $0=\mathrm{NA}$ )

Method

\begin{tabular}{ccc}
\multicolumn{2}{c}{ Teacher } & \multicolumn{2}{c}{ Principal } \\
Mean SD
\end{tabular}

In-service programs

3.

New teacher orientation program

3.2

1.0

3.0

1.0

Fine arts supervisor

3.8

1.4

3.4

1.1

Other music teachers in school

3.9

1.3

3.4

1.7

Other non-music teachers in school

3.2

1.0

3.8

1.4

Colleagues in music field

4.5

1.0

3.9

.70

Assigned mentor teacher (non-music)

1.6

.60

3.9

1.2

Assigned mentor teacher (music)

3.0

1.7

3.0

.96

Music workshops or conferences

4.4

2.2

3.5

1.5

Release time to observe experienced

music teachers

3.8

.82

3.9

.70

Accessibility of administrator

4.0

1.8

3.8

.63

Administrators' visits to classroom

3.2

.79

4.2

1.3

Administrative assistance with

classroom management

3.0

1.1

3.6

Administrative assistance with

budget preparation

2.2

1.6

3.8

1.1

Assistance with administrative duties

(fundraising, trips, competitions)

2.7

1.8

4.0

.75

Administrative assistance with large classes

2.7

1.9

3.8

.74

Release time to work with feeder school choirs 2.7

1.9

3.6

1.2

Release time for performances

outside of school

3.9

1.2

3.4

1.2

Release time for recruiting students from other schools 
Division of subjects by Years of Teaching Experience showed that a significant positive relationship existed between ratings of teachers and principals of teachers with 1 to 1.5 years of teaching experience (See Table 4.118 ).

Table 4.118: Correlation of mean teacher/principal responses to value of 19 methods of assistance by Years of Teaching Experience

\begin{tabular}{lcc}
\hline Years & rs & $\mathrm{p}$ \\
\hline 1 to 1.5 & .53 & $.008 *$ \\
2 & .37 & .11 \\
3 to 3.5 & .33 & .16 \\
4 & .32 & .17 \\
5 & .20 & .39 \\
$*$ Indicates significant positive correlation $\mathrm{p}<.05$ & \\
\hline
\end{tabular}

\section{$\underline{\text { Teacher Attrition and Retention }}$}

Early career secondary choral directors were asked to measure their intention to either stay or leave the teaching profession using a 5-point Likert scale, with $1=$ Definitely plan to leave after this year and $5=$ Definitely plan to stay after this year. Analysis seemed to indicate that the early career teachers intended to stay in the teaching profession $($ Mean $=4.2 ;$ S. D. $=1.0)$.

Intention to either stay or leave the teaching profession was further examined by division of subjects into subgroups. Table 4.119 illustrates the subjects' intentions by 
Regions. Teachers in Region $20($ Mean $=3.6)$ had the lowest intention rate of the 5

Regions.

Table 4.119: Intention of early teachers to either stay or leave the teaching profession by Region ( 1 = leave; 5 = stay $)$

\begin{tabular}{rccc}
\hline Region & $\mathrm{n}$ & Mean & SD \\
\hline 3 & 20 & 4.3 & 1.1 \\
5 & 27 & 4.3 & .91 \\
7 & 6 & 4.0 & .63 \\
20 & 13 & 3.6 & 1.3 \\
24 & 21 & 4.4 & .66 \\
\hline
\end{tabular}

The division of subjects by District is presented in Table 4.120. Teachers' intentions in all of the districts measured a mean of 4.0 or higher, with the highest mean (4.4) in Districts D and E - I.

Table 4.120: Intention of early career teachers to either stay or leave the teaching profession by District ( $1=$ leave; $5=$ stay $)$

\begin{tabular}{lccc} 
District & $\mathrm{n}$ & Mean & SD \\
\hline A & 24 & 4.3 & 1.0 \\
B & 21 & 4.1 & 1.2 \\
C & 25 & 4.0 & 1.0 \\
D & 10 & 4.4 & .84 \\
E - I & 7 & 4.4 & .78 \\
\hline
\end{tabular}


Table 4.121 presents the data by School Type. The intention of staying in the teaching profession was higher among teachers in suburban school than among teachers in rural and urban schools.

Table 4.121: Intention of early career teachers to either stay or leave the teaching profession by School Type ( 1 = leave; 5 = stay)

\begin{tabular}{lccc}
\hline School Type & $n$ & Mean & SD \\
\hline Rural & 5 & 3.8 & .83 \\
Suburban & 57 & 4.4 & .83 \\
Urban & 25 & 3.9 & 1.3 \\
\hline
\end{tabular}

Table 4.122 shows the data subdivided into School Level. Teachers in each of the 3 levels had a mean of 4.1 or higher, with junior high teachers showing the highest intention rate of staying in the teaching profession.

Table 4.122: Intention of early career teachers to either stay or leave the teaching profession by School Level ( $1=$ leave; 5 = stay $)$

\begin{tabular}{lccc} 
School Level & $n$ & Mean & SD \\
\hline High School & 26 & 4.1 & .95 \\
Junior High School & 19 & 4.4 & 1.0 \\
Middle School & 42 & 4.1 & 1.0 \\
\hline
\end{tabular}

When categorized by Conference (See Table 4.123), teachers' intentions to stay or leave the teaching profession ranged from the lowest rating among teachers in 
Conference AAAAA schools to the highest rating among teachers in Conference BB BBB schools.

Table 4.123: Intention of early career teachers to either stay or leave the teaching profession by Conference ( $1=$ leave; $5=$ stay $)$

Conference

nean

SD

AA - AAAA

13

4.3

.76

AAAAA

13

3.8

1.0

$\mathrm{BB}-\mathrm{BBB}$

6

4.5

.51

CC

4.1

1.1

$\mathrm{CCC}$

29

4.3

1.0

Examination of the data by Years of Teaching Experience (See Table 4.124) indicated that teachers with 4 years of teaching experience had a higher intention rate of leaving the teaching profession than teachers with 5 years of teaching experience.

Table 4.124: Intention of early career teachers to either stay or leave the teaching profession by Years of Teaching Experience ( $1=$ leave; $5=$ stay $)$

Years of Teaching Experience

$n$

Mean

SD

$1-1.5$ years

16

4.1

1.4

2 years

18

4.0

.93

$3-3.5$ years

20

4.4

.82

4 years

13

3.5

1.2

5 years

20

4.6

.67 
Viewing the data with teachers subdivided in accordance to the number of years they had taught at their present school (See Table 4.125) revealed that teachers who had taught from 1 to 1.5 years at their present school had a lower intention rate of staying in the teaching profession than teachers who had taught for 5 years at their present school.

Table 4.125: Intention of early career teachers to either stay or leave the teaching profession by Years in Current Teaching Position ( $1=$ leave; $5=$ stay $)$

\begin{tabular}{lccc} 
Years in Current Teaching Position & $n$ & Mean & SD \\
\hline 1-1.5 years & 34 & 3.9 & 1.3 \\
2 years & 22 & 4.2 & .88 \\
3 years & 20 & 4.0 & 1.0 \\
4 years & 6 & 4.6 & .81 \\
5 years & 5 & 4.8 & .44 \\
\hline
\end{tabular}

Table 4.126 presents teachers' intentions to either stay or leave the teaching profession in terms of Position on Choral Staff. The mean (4.2) was the same among both groups.

Table 4.126: Intention of early career teachers to either stay or leave the teaching profession by Position on Choral Staff ( 1 = leave; $5=$ stay $)$

\begin{tabular}{lccr} 
Position on Choral Staff & $n$ & Mean & SD \\
\hline Head director & 58 & 4.2 & 1.0 \\
Assistant director & 29 & 4.2 & .94 \\
\hline
\end{tabular}


When subjects were divided in terms of the Number of People on Choral Staff

(See Table 4.127), data indicated that the groups each had the same mean (4.2).

Table 4.127: Intention of early career teachers to either stay or leave the teaching profession by Number of People on Choral Staff ( $1=$ leave; 5 = stay $)$

\begin{tabular}{lccc} 
Number of People on Choral Staff & $n$ & Mean & SD \\
\hline 1 person & 46 & 4.2 & 1.1 \\
$1.5-3$ people & 41 & 4.2 & .92 \\
\hline
\end{tabular}

Out of the 87 respondents, $12(13.7 \%)$ indicated that they intended to leave the teaching profession. Teachers intending to leave the profession were provided a checklist of reasons for leaving. Table 4.128 presents the frequency and percentage of each factor selected by the respondents. The 12 teachers who intended to leave offered a total of 57 responses. The 2 respondents who selected Other from the checklist offered the following reasons for leaving the teaching profession: completion of DMA and to pursue career in school counseling.

Table 4.128: Frequency and percentage of early career teachers' reasons for intending to leave the teaching profession $(n=12)$

Reason

Frequency

Percentage

Lack of student motivation

5

Pursue other music career

Job Stress

Attend graduate school in music

Lack of student discipline
5

5

5

5
41.6

41.6

41.6

41.6

41.6 
Table 4.128: Continued

\begin{tabular}{lcc}
\hline Reason & Frequency & Percentage \\
\hline Inadequate administrative support & 5 & 41.6 \\
Lack of parental/community support & 3 & 25.0 \\
Scheduling issues & 3 & 25.0 \\
Pregnancy/Child care & 3 & 25.0 \\
Low salary & 2 & 16.6 \\
Multi-campus duties & 2 & 16.6 \\
Workload issues & 2 & 16.6 \\
Moving & 2 & 16.6 \\
Lack of influence over school policies & 2 & 16.6 \\
Classes too large & 2 & 16.6 \\
Other & 2 & 16.6 \\
Lack of adequate preparation time & 1 & 8.3 \\
Isolation & 1 & 8.3 \\
Unsafe environment & 1 & 8.3 \\
Pursue career outside of music & 0 & 8.3 \\
Health & 1 & 0.3 \\
Poor opportunities for advancement & & 0.0 \\
Elimination of program & & 0.0 \\
Reduction in staff & & \\
Total of 57 responses & & \\
\hline & & \\
\hline
\end{tabular}

A demographic profile of the early career secondary choral directors intending to leave the teaching profession was created by dividing the subjects into subgroups. Division of subjects into Regions (See Table 4.129) revealed that the largest number of 
teachers (4) intending to leave the teaching profession were in Region 20 (33.3\%) and the smallest number (1) was in Region 24 (8.3\%).

Table 4.129: Frequency and percentage of early career teachers intending to leave the teaching profession by Region $(\mathrm{n}=12)$

\begin{tabular}{rcc}
\hline Region & Frequency & Percentage \\
\hline 3 & 3 & 25.0 \\
5 & 2 & 16.6 \\
7 & 2 & 16.6 \\
20 & 4 & 33.3 \\
24 & 1 & 8.3 \\
\hline
\end{tabular}

Looking at subjects divided by District (See Table 4.130) showed that teachers from District E - I (8.3\%) indicated the least intention to leave the teaching profession, whereas Districts B, C, and D were tied with $25 \%$.

Table 4.130: Frequency and percentage of early career teachers intending to leave the teaching profession by District $(n=12)$

District

A

B

$\mathrm{C}$

$\mathrm{D}$

E - I
Frequency

2

3

3

3

1

Percentage

16.6

25.0

25.0

25.0

8.3 
Table 4.131 provides a view of the data categorized by School Type. The highest number of subjects (7) indicating that they intended to leave the teaching profession were in urban schools (58.3\%).

Table 4.131: Frequency and percentage of early career teachers intending to leave the teaching profession by School Type $(\mathrm{n}=12)$

\begin{tabular}{lcc} 
School Location & Frequency & Percentage \\
\hline Rural & 1 & 8.3 \\
Suburban & 4 & 33.3 \\
Urban & 7 & 58.3 \\
\hline
\end{tabular}

Subjects categorized by School Level (See Table 4.132) indicated that an equal number of teachers (5) in high schools and middle schools intended to leave the teaching profession, with only 2 teachers on the junior high level intending to leave.

Table 4.132: Frequency and percentage of early career teachers intending to leave the teaching profession by School Level $(\mathrm{n}=12)$

\begin{tabular}{lcc} 
School Level & Frequency & Percentage \\
\hline High School & 5 & 41.6 \\
Junior High School & 2 & 16.6 \\
Middle School & 5 & 41.6
\end{tabular}

Examination of the data by Conference (See Table 4.133) revealed that teachers that had the highest intention rate to leave the teaching profession were in Conference CC 
schools (41.6\%) and those with the lowest intention rate to leave were in Conference BB - BBB schools (0\%).

Table 4.133: Frequency and percentage of early career teachers intending to leave the teaching profession by Conference $(n=12)$

Conference

Frequency

Percentage

AA - AAAA

8.3

AAAAA

4

33.3

$\mathrm{BB}-\mathrm{BBB}$

0

0.0

$\mathrm{CC}$

5

41.6

$\mathrm{CCC}$

2

16.6

When subjects were categorized by Years of Teaching Experience (See Table 4.134), it was found that teachers with 2 years of teaching experience (33.3\%) had the highest intention to leave the teaching profession, while those with 3 to 3.5 years $(8.3 \%)$ and 5 years $(8.3 \%)$ had the highest intention to stay.

Table 4.134: Frequency and percentage of early career teachers intending to leave the teaching profession by Years of Teaching Experience $(n=12)$

Years of Teaching Experience

Frequency

Percentage

$1-1.5$ years

3

25.0

2 years

4

33.3

$3-3.5$ years

1

8.3

4 years

2

16.6

5 years

1

8.3 
Viewing subjects in terms of the number of Years in Current Teaching Position (See Table 4.135) revealed that teachers who had taught at their present school for 1 to 1.5 years $(58.3 \%)$ had the highest intention to leave the teaching profession, whereas $0 \%$ of teachers who had taught at their present school for 4 or 5 years intended to leave.

Table 4.135: Frequency and percentage of early career teachers intending to leave the teaching profession by Years in Current Teaching Position $(n=12)$

\begin{tabular}{lcr}
\hline Years in Current Teaching Position & Frequency & Percentage \\
\hline $1-1.5$ years & 7 & 58.3 \\
2 years & 3 & 25.0 \\
3 years & 2 & 16.6 \\
4 years & 0 & 0.0 \\
5 years & 0 & 0.0 \\
\hline
\end{tabular}

Table 4.136 presents subjects in terms of Position on Choral Staff. Data indicates that Assistant Directors (58.3\%) reported a higher intention to leave the teaching profession than Head Directors (41.6\%).

Table 4.136: Frequency and percentage of early career teachers intending to leave the teaching profession by Position on Choral Staff $(n=12)$

Position on Choral Staff $\quad$ Frequency $\quad$ Percentage

Head director

Assistant director
5
41.6

58.3 
Division of subjects by Number of People on Choral Staff (See Table 4.137)

showed that teachers in schools with 1.5 to 3 people on the choral staff $(75.0 \%)$ reported the higher rate of intention to leave the teaching profession.

Table 4.137: Frequency and percentage of early career teachers intending to leave the teaching profession by Number of People on Choral Staff $(n=12)$

\begin{tabular}{ccc} 
Number of People on Choral Staff & Frequency & Percentage \\
\hline 1 person & 3 & 25.0 \\
$1.5-3$ people & 9 & 75.0 \\
\hline
\end{tabular}

The Spearman rank correlation procedure was conducted to determine the correlation of teachers who plan to leave the teaching profession and their principals regarding their philosophy of music education. Eight out of 12 principals responded to the questionnaire. Table 4.138 presents the teacher/principal correlation and shows a significant positive correlation between only three subjects and their principals.

Table 4.138: Correlation of teacher/principal philosophy of music education among early career teachers intending to leave the teaching profession

\begin{tabular}{rcc} 
Subject & $r_{s}$ & $p$ \\
\hline 4 & .69 & $.001 *$ \\
7 & .15 & .55 \\
10 & .09 & .70 \\
13 & .43 & .07 \\
36 & .68 & $.001 *$ \\
54 & .30 & .21
\end{tabular}


Table 4.138: Continued

\begin{tabular}{lcc} 
Subject & $r_{s}$ & $p$ \\
\hline 60 & .65 & $.003 *$ \\
72 & .31 & .21
\end{tabular}

Probability calculated for two-tailed $t$ test, $\mathrm{n}=18, d f=16$

* Indicates significant positive correlation $\mathrm{p}<.05$

Spearman rank correlation was calculated to find the correlation of teachers who plan to leave the teaching profession and their principals regarding the value of various forms of administrative assistance. The data, presented in Table 4.139, shows a significant positive correlation between only 3 subjects and their principals. In addition, two subjects show a non-significant negative correlation.

Table 4.139: Correlation of teacher/principal perception of professional assistance among early career teachers intending to leave the teaching profession

\begin{tabular}{ccc} 
Subject & $r_{s}$ & $p$ \\
\hline 4 & .10 & .67 \\
7 & .73 & $.0003 *$ \\
10 & -.10 & $.66 * *$ \\
13 & .19 & .42 \\
36 & .46 & $.04 *$ \\
54 & -.11 & $.64 * *$ \\
60 & .53 & $.01 *$ \\
72 & .37 & .11 \\
Probability calculated for two-tailed $t$ test, $\mathrm{n}=19, d f=17$. &
\end{tabular}


Table 4.139: Continued

* Indicates significant positive correlation $\mathrm{p}<.05$

** Indicates non-significant negative correlation $\mathrm{p}<.05$

Teachers who indicated that they intended to stay in the teaching profession $(\mathrm{n}=$ 74) were provided a checklist from which to select reasons for staying (See Table 4.140). Some of the 74 respondents chose multiple factors, resulting in a total of 363 responses. The top 5 reasons selected included: support of other teachers, school environment, student motivation, administrative support, and schedule.

Table 4.140: Frequency and percentage of early career teachers' reasons for intending to stay the teaching profession $(n=74)$

Reason

Frequency

Percentage

Support of other teachers

School environment

40

54.0

Student motivation

39

52.7

Administrative support

36

48.6

Schedule

36

48.6

Salary

31

41.8

Opportunities for advancement

23

31.0

Parental/community support

22

29.7

Class size

21

28.3

Adequate preparation time

20

27.0

Student discipline

20

27.0

Other

19

25.6

Workload

12

16.2 
Table 4.140: Continued

\begin{tabular}{lcc} 
Reason & Frequency & Percentage \\
\hline Influence over school policies & 3 & 4.0 \\
Total responses -363 & & \\
\hline
\end{tabular}

Nineteen teachers selected Other from the checklist of factors for staying in the teaching profession. Based on a procedure used by DeLorenzo (1992), Other responses were divided into 3 categories: intrinsic, professional, and personal (See Table 4.141). Some of the 19 respondents provided more than one reason, resulting in a total of 22 responses. A complete list of the Other responses in found in Appendix H .

Table 4.141: Other reasons for staying in the teaching profession

Category Frequency

Intrinsic

Love to teach children music 3

Love students 3

Enjoyable students $\quad 2$

Enjoy making a difference in students' lives $\quad 1$

Love music 1

$\begin{array}{lr}\text { Total } & 10\end{array}$

Professional

Want to build a choir program 2

Scheduling of classes $\quad 1$

Develop skills to move to higher school level 1 
Table 4.141: Continued

\begin{tabular}{lc}
\hline \multicolumn{1}{c}{ Category } & Frequency \\
\hline Gain experience & 1 \\
Hope that next year will be different & 1 \\
Total & 6 \\
Personal & \\
Time for parenting & 2 \\
Financial & 2 \\
Benefits & 1 \\
Family support of teaching career & 1 \\
Total & 6 \\
Total of 22 responses & \\
\hline
\end{tabular}

\section{Teacher Intention to Stay or Leave Current Teaching Position}

The 74 teachers who indicated they intended to stay in the teaching profession were polled regarding their intention to either stay or leave their present teaching assignment. Subjects were asked to respond using a 5-point Likert scale: $1=$ Definitely plan to change schools after this year and $5=$ Definitely plan to stay at this school after this year. The overall results indicated that the teachers intended to stay in their current teaching assignment $($ Mean $=3.9 ; \mathrm{SD}=1.0)$.

Subjects' intentions to either stay or leave their current teaching position were also analyzed by subgroups. Examination of subjects by region showed that those in Region 20 reported the highest intention to change schools and those in Region 24 reported the lowest intention to change schools (See Table 4.142). 
Table 4.142: Intention of early career teachers to either stay or leave their present teaching assignment by Region ( $1=$ leave; $5=$ stay $)$

\begin{tabular}{cccc}
\hline Region & $n$ & Mean & SD \\
\hline 3 & 17 & 3.7 & 1.3 \\
5 & 25 & 4.0 & .83 \\
7 & 4 & 3.7 & 1.5 \\
20 & 8 & 3.5 & .92 \\
24 & 20 & 4.2 & .85 \\
\hline
\end{tabular}

Viewing subjects' intentions to stay or leave their present teaching assignment by District revealed that teachers in District B schools indicated the strongest intention to remain in their current school, whereas teachers in District A and District D schools indicated the strongest intention to change teaching positions (See Table 4.143).

Table 4.143: Intention of early career secondary choral directors to either stay or leave their present teaching assignment by District $(1=$ leave; $5=$ stay $)$

\begin{tabular}{lccc} 
District & $n$ & Mean & SD \\
\hline A & 21 & 3.8 & 1.1 \\
B & 18 & 4.1 & 1.1 \\
C & 22 & 4.0 & .75 \\
D & 7 & 3.8 & .89 \\
E - I & 6 & 4.0 & 1.0 \\
\hline
\end{tabular}


Table 4.144 presents the data for teachers' intentions to either stay or leave their present teaching assignment according to School Type. Teachers in rural and urban had higher intention rates of leaving their current school than did their suburban counterparts.

Table 4.144: Intention of early career teachers to either stay or leave their present teaching assignment by School Type ( $1=$ leave; 5 = stay $)$

\begin{tabular}{lccc}
\hline School Type & $n$ & Mean & SD \\
\hline Rural & 4 & 3.5 & 1.7 \\
Suburban & 53 & 4.0 & .77 \\
Urban & 17 & 3.5 & 1.3 \\
& & & \\
\hline
\end{tabular}

Analysis of data by School Level (See Table 4.145) disclosed that teachers in high schools had a higher intention to remain in their current teaching assignment than did teachers in junior high and middle schools.

Table 4.145: Intention of early career teachers to either stay or leave their present teaching assignment by School Level $(1=$ leave; $5=$ stay $)$

School Level

$n$

Mean

SD

High School

20

4.3

.74

Junior High School

17

3.7

1.0

Middle School

37

3.8

1.0

An examination of the data in terms of Conference (See Table 4.146) revealed that teachers in Conference AAAAA schools reported a stronger intention to remain in their present teaching situation than those in Conference BB - BBB schools. 
Table 4.146: Intention of early career teachers to either stay or leave their present teaching assignment by Conference $(1=$ leave; $5=$ stay $)$

\begin{tabular}{lccc}
\hline Conference & $n$ & Mean & SD \\
\hline AA - AAAA & 11 & 4.1 & .87 \\
AAAAA & 9 & 4.5 & .52 \\
BB - BBB & 6 & 3.5 & 1.3 \\
CC & 21 & 4.0 & .92 \\
CCC & 27 & 3.6 & 1.0 \\
\hline
\end{tabular}

When subjects were divided according to Years of Teaching Experience (See

Table 4.147), it was found that teachers with 4 years of teaching experience indicated the highest intention to leave their current position, while teachers with 5 years of teaching experience reported the highest intention to remain in their present job.

Table 4.147: Intention of early career teachers to either stay or leave their present teaching assignment by Years of Teaching Experience $(1=$ leave; $5=$ stay)

\begin{tabular}{lrrr} 
Years of Teaching Experience & $n$ & Mean & SD \\
\hline 1-1.5 years & 14 & 4.0 & 1.1 \\
2 years & 14 & 3.9 & 1.2 \\
$3-3.5$ years & 19 & 3.9 & .91 \\
4 years & 9 & 3.1 & .78 \\
5 years & 18 & 4.2 & .89 \\
\hline
\end{tabular}

Table 4.148 explicates the division of subjects in terms of the number of years they have taught at their present school. Teachers in their fourth year at their present 
school had a higher rate of intention to change schools than teachers in their fifth year at their present school.

Table 4.148: Intention of early career teachers to either stay or leave their present teaching assignment by Years in Current Teaching Position $(1=$ leave; $5=$ stay)

\begin{tabular}{lccc} 
Years in Current Teaching Position & $n$ & Mean & SD \\
\hline 1- 1.5 years & 27 & 4.0 & 1.1 \\
2 years & 19 & 3.9 & .91 \\
3 years & 17 & 3.8 & 1.0 \\
4 years & 6 & 3.3 & .51 \\
5 years & 5 & 4.6 & .54 \\
\hline
\end{tabular}

Examination of subjects with regard to Position on Choral Staff (See Table 4.149) indicates that assistant directors had a higher intention to change teaching jobs than head directors.

Table 4.149: Intention of early career teachers to either stay or leave their present teaching assignment by Position on Choral Staff ( $1=$ leave; $5=$ stay $)$

\begin{tabular}{lccc}
\hline Position on Choral Staff & $n$ & Mean & SD \\
\hline Head director & 52 & 4.0 & 1.0 \\
Assistant director & 22 & 3.8 & .95 \\
\hline
\end{tabular}

No difference was found between the intention of subjects to stay or leave their current teaching assignment with respect to the Number of People on Choral Staff (See Table 4.150). 
Table 4.150: Intention of early career teachers to either stay or leave their present teaching assignment by Number of People on Choral Staff $(1=$ leave; $5=$ stay)

\begin{tabular}{cccc} 
Number of People on Choral Staff & $n$ & Mean & SD \\
\hline 1 person & 41 & 3.9 & 1.0 \\
$1.5-3$ people & 33 & 3.9 & 1.0 \\
\hline
\end{tabular}

A checklist of reasons was provided for the early career secondary choral directors $(n=17)$ who indicated that they intended to change teaching positions. Table 4.151 presents the frequency and percentage of each factor affecting teachers' intentions to change jobs. Subjects chose a total of 88 responses.

Table 4.151: Frequency and percentage of early career teachers' reasons for intending to change schools $(n=17)$

\section{Reason}

Frequency

Percentage

Other

10

58.8

Job stress

9

52.9

Lack of student motivation

Lack of student discipline

Workload issues

Scheduling issues

Inadequate administrative support

Lack of influence over school policies

Lack of parental/community support

Low salary

Isolation 
Table 4.151: Continued

\begin{tabular}{lcc} 
Reason & Frequency & Percentage \\
\hline Lack of adequate preparation time & 3 & 17.6 \\
Poor opportunities for advancement & 3 & 17.6 \\
Multi-campus duties & 3 & 17.6 \\
Classes too large & 3 & 17.6 \\
Moving & 3 & 17.6 \\
Pregnancy/Children & 2 & 11.7 \\
Elimination of program & 1 & 5.8 \\
Unsafe environment & 1 & 5.8 \\
Reduction in staff & 0 & 0.0 \\
Total of 88 responses & &
\end{tabular}

The factor that received the highest level of response (58.8\%) was Other. Some of the 10 subjects who selected Other listed more than one factor, resulting in a total of 13 responses (See Table 4.152). A complete list of Other factors is presented in Appendix I.

Table 4.152: Other reasons for early career teachers intention to change schools

Reason

Frequency

Work with older students 3

Location of school 2

Discipline problems

School closing 1

Better position 1

Increase in stipend 1 
Table 4.152: Continued

Reason

Frequency

Transfer

1

Servicing 2 campuses

1

Inadequate skills

1

Not being full time

1

Total responses -13

In order to establish a demographic profile of teachers intending to change teaching positions, subjects were divided into subgroups. Division by Region showed that teachers in Region 20 reported the highest intention to change schools and teachers in Region 7 reported the lowest intention (See Table 4.153).

Table 4.153: Early career teacher intention to change current teaching assignment by Region

\begin{tabular}{ccc} 
Region & $\mathrm{n}$ & Percentage \\
\hline 3 & 4 & 23.5 \\
5 & 3 & 17.6 \\
7 & 2 & 11.7 \\
20 & 5 & 29.4 \\
24 & 3 & 17.6 \\
\hline
\end{tabular}

Examination of subjects by Districts revealed that highest percentage of teachers intending to change schools were in District A schools, while the lowest percentage was in District B schools (See Table 4.154). 
Table 4.154: Early career teacher intention to change current teaching assignment by District

District

\begin{tabular}{lcc}
\hline A & 5 & 29.4 \\
B & 2 & 11.7 \\
C & 3 & 17.6 \\
D & 4 & 23.5 \\
E-I & 3 & 17.6 \\
\hline
\end{tabular}

Percentage

When viewing subjects in terms of School Type, it was found that the highest percentage of teachers intending to change their current teaching position were in Suburban schools (See Table 4.155).

Table 4.155: Early career teacher intention to change current teaching assignment by School Type

\begin{tabular}{lcc}
\hline School Type & $\mathrm{n}$ & Percentage \\
\hline Rural & 2 & 11.7 \\
Suburban & 11 & 64.7 \\
Urban & 4 & 23.5 \\
\hline
\end{tabular}

Categorization of subjects by School Level revealed that the middle school teachers had a higher intention to change schools than teachers in high schools and junior high schools (See Table 4.156) 
Table 4.156: Early career teacher intention to change current teaching assignment by School Level

School Level

High School

Junior High School

Middle School $\mathrm{n}$

5

3

9
Percentage

29.4

17.6

52.9

Examination of subjects by Conference indicated that teachers in Conference CCC schools $(41.1 \%)$ had the highest percentage rate of intention to leave their current school, whereas teachers in Conference BB - BBB schools $(0 \%)$ had the lowest percentage (See Table 4.157).

Table 4.157: Early career teacher intention to change current teaching assignment by Conference

Conference

AA - AAAA

AAAAA

$\mathrm{BB}-\mathrm{BBB}$

CC

CCC n

4

1

0

5

7
Percentage

23.5

5.8

0.0

29.4

41.1

Viewing the data in terms of years of teaching experience disclosed that teachers with 1 to 1.5 years of teaching experience $(29.4 \%)$ had the highest percentage of intention 
to leave their current school, while teachers with 2 years of teaching experience $(11.7 \%)$ had the lowest percentage (See Table 4.158).

Table 4.158: Early career teacher intention to change current teaching assignment by Years of Teaching Experience

Years of Teaching Experience

$1-1.5$ years

2 years

$3-3.5$ years

4 years

5 years n

Percentage

Table 4.159 shows division of subjects in terms of the number of years at their present school. Subjects who have taught at their present school for $1-1.5$ years and 3 years reported the highest intention to change schools.

Table 4.159: Early career teacher intention to change current teaching assignment by Years in Current Teaching Position

\begin{tabular}{lcc} 
Years in Current Teaching Position & $\mathrm{n}$ & Percentage \\
\hline $1-1.5$ years & 6 & 35.2 \\
2 years & 5 & 29.4 \\
3 years & 6 & 35.2 \\
4 years & 0 & 0.0 \\
5 years & 0 & 0.0 \\
\hline
\end{tabular}


In terms of Position on Choral Staff, a higher percentage of head directors intend to change current teaching positions, than assistant directors (See Table 4.160).

Table 4.160: Early career teacher intention to change current teaching assignment by Position on Choral Staff

\begin{tabular}{lcc} 
Position on Choral Staff & $\mathrm{n}$ & Percentage \\
\hline Head director & 10 & 58.8 \\
Assistant director & 7 & 41.1 \\
\hline
\end{tabular}

Examination of subjects in terms of Number of People on Choral Staff indicates that a higher percentage of teachers in schools with 1 person on the choral staff (64.7\%) intended to change their current teaching position (See Table 4.161)

Table 4.161: Early career teacher intention to change current teaching assignment by Number of People on Choral Staff

\begin{tabular}{llc} 
Number of People on Choral Staff & $\mathrm{n}$ & Percentage \\
\hline 1 person & 11 & 64.7 \\
$1.5-3$ people & 6 & 35.2 \\
\hline
\end{tabular}

The Spearman rank correlation procedure was used to compare the philosophy of music education of early career secondary choral directors intending to leave their current teaching position with that of their administrators (See Table 4.162). Twelve out of 17 principals responded to the interview. Results indicated that only 4 subjects $(16,19,21$, and 59) had a significant positive correlation with their administrators' views of music education. 
Table 4.162: Correlation of teacher/principal philosophy of music education of early career teachers intending to leave their current teaching position

\begin{tabular}{lll}
\hline Subject & $r_{s}$ & $p$ \\
\hline 3 & .32 & .18 \\
16 & .59 & $.008^{*}$ \\
19 & .55 & $.01 *$ \\
21 & .45 & $.05 *$ \\
32 & .39 & .10 \\
52 & .20 & .41 \\
55 & .39 & .10 \\
59 & .52 & $.02 *$ \\
72 & .31 & .21 \\
79 & .25 & .31 \\
83 & .44 & .06 \\
86 & .23 & .35 \\
Probability calculated for two-tailed $t$ test, $\mathrm{n}=18, d f=16$ & \\
$*$ Indicates significant positive correlation $\mathrm{p}<.05$ & \\
\hline
\end{tabular}

The Spearman rank correlation procedure was utilized to compare the value designated to various forms of professional assistance by early career secondary choral directors intending on changing schools and their principals (See Table 4.163). Not a 
single pair of teacher and principal had a significant positive correlation regarding their perception of administrative support.

Table 4.163: Correlation of teacher/principal perception of professional assistance among early career teachers intending to leave their current teaching position

\begin{tabular}{lll}
\hline Subject & $\mathrm{r}_{\mathrm{s}}$ & $\mathrm{p}$ \\
\hline 3 & .36 & .12 \\
16 & .12 & .62 \\
19 & .24 & .31 \\
21 & .22 & .36 \\
32 & .23 & .34 \\
52 & .24 & .31 \\
55 & .10 & .67 \\
59 & -.20 & $.41 *$ \\
72 & .37 & .11 \\
79 & -.02 & $.91 *$ \\
83 & .43 & .06 \\
86 & .28 & .23 \\
Probability calculated for two-tailed $t$ test, $\mathrm{n}=19, d f=17$ & \\
$*$ Indicates non-significant negative correlation $\mathrm{p}<.05$ & \\
\hline & & \\
\hline
\end{tabular}




\section{$\underline{\text { Interviews }}$}

Interviews were conducted to help explain the salient issues that appeared in the analysis of the quantitative data. Questions focused on early career teacher's perception of community/parent support, administrative support, support of other faculty members, school environment and the primary factors that impacted the teacher's decision to either stay in teaching or to leave the profession.

Interviewees were selected to represent all subgroups (See Tables 4.164 and 4.165). A total of 9 interviews were conducted between the dates of February 9 and February 12, 2005. All interviews were taped and complete transcripts appear in Appendix J. Interviews were designed to help explicate the quantitative data and excerpts appear in the Discussion section.

Table 4.164: Demographic profile of interviewees

\begin{tabular}{ccclll}
\hline Subject \# & Region & District & $\begin{array}{c}\text { School } \\
\text { Type }\end{array}$ & $\begin{array}{l}\text { School } \\
\text { Level }\end{array}$ & Conference \\
\hline 4 & 7 & E & Rural & Junior High & CC \\
5 & 7 & D & Suburban & High School & AAAA \\
16 & 3 & D & Suburban & High School & AAAA \\
24 & 3 & C & Suburban & Middle School & CCC \\
35 & 5 & A & Urban & Junior High & CCC \\
63 & 20 & D & Suburban & High School & AAAAA \\
67 & 24 & B & Suburban & Middle School & CC \\
74 & 24 & D & Suburban & High School & AAAA \\
84 & 24 & C & Suburban & High School & AAAA \\
\hline
\end{tabular}


Table 4.165: Teaching profile of interviewees

\begin{tabular}{ccccc}
\hline Subject \# & Years of Teaching & Years at School & Position & Number of Staff \\
\hline 4 & 2 & 1 & A & 2 \\
5 & 4 & 1 & H & 2 \\
16 & 1 & 1 & A & 2 \\
24 & 3 & 2 & H & 1 \\
35 & 4 & 4 & A & 2 \\
63 & 2 & 2 & A & 2 \\
67 & 3.5 & 2 & H & 1 \\
74 & 5 & 2 & H & 2 \\
84 & 5 & 5 & A & 2 \\
\hline
\end{tabular}




\section{CHAPTER V \\ DISCUSSION}

\section{Discussion of Major Findings}

Overall, early career secondary choral directors reported that they were satisfied with their current teaching position. Seventy-four out of the 87 respondents $(85.0 \%)$ reported that they were somewhat or very satisfied with their current teaching position. When asked what would increase their job satisfaction in their current teaching position, the majority of early career teachers (60.9\%) named community/parent support, followed by higher salary $(58.6 \%)$.

The methods of assistance early career secondary choral directors ranked as being most beneficial were colleagues in music field and music workshops or conferences. On the other hand, administrators ranked accessibility of administrator as being most helpful, followed by administrative assistance with classroom management and colleagues in

music field. Teachers only ranked 8 out of 19 listed methods as being beneficial (with a mean of 3.0 or higher), whereas principals ranked 18 out of 19 methods as being helpful. This suggests that administrators' and teachers' perceptions of the value of various methods of assistance are quite different.

A greater number of early career secondary choral directors (17) indicated that they intended to leave their current teaching position than indicated that they intended to leave the teaching profession (12). Some of the factors influencing a new teacher's propensity to leave the teaching profession were similar to reasons given for leaving their current job. Among teachers leaving the profession or changing schools, data suggested 
that there was a low level of agreement between teachers and their principals with regard to philosophy of education or value of methods of assistance.

Factors affecting an early career teacher's desire to stay in teaching were primarily issues of support, school environment, and student motivation.

\section{Teacher Job Satisfaction}

When early career teachers were asked to rank their job satisfaction using a 5point Likert scale, ranging from 1 (very dissatisfied) to 5 (very satisfied), the mean was 4.1. Examination of subgroups revealed that several subdivisions of early career teachers had a job satisfaction rating far below the mean of 4.1. Early career teachers in Region 20 had a mean of 3.8. Perhaps this can be attributed to the large number of urban teachers in this Region. Teachers in District D schools, with a population of 5,000 to 9,999, had a mean of 3.7. Early career educators in rural (Mean $=3.8)$ and urban (Mean =3.9) had a job satisfaction ranking below the mean for the total group. The lowest mean of job satisfaction, 3.6, was reported by teachers with 4 years of teaching experience.

The factors that early career teachers most frequently selected from a checklist of methods to increase their job satisfaction largely dealt with issues of support. These support issues included: community/parent support (60.9\%); administrative support (41.3\%); support of other faculty members (39.0\%); and support with discipline problems $(37.9 \%)$.

These findings are consistent with Norton (1999) who reported that the stronger the administrative support, the greater the job satisfaction. Likewise, DeLorenzo (1992) 
and Heston, Dedrick, Raschke, and Whitehead (1996) found that music teachers listed positive administrative support was one of the most satisfying aspects of their jobs.

On the other hand, Heston et al (1996) discovered that the area of teaching that music educators found the least satisfying was lack of support from administration, parents, and community. In addition, Krueger (2000) and Scheib (2003) cited inadequate administrative support and a lack of support network as factors influencing early career teachers' dissatisfaction with teaching. Similarly, Mercer and Mercer (1986) included discipline problems and conflicts with school administrators and other teachers as factors contributing to job dissatisfaction.

Thus, research supports the findings of this study that indicate that early career teacher job satisfaction is closely associated with issues of community/parent support, administrative support, support of other faculty members, and support with discipline problems

Because community/parent support was the primary factor selected by early career teachers as affecting job satisfaction, interviewees were asked to describe the nature of parent and community support they receive for their program. Some of the interviewees' responses regarding parent and community support follow:

Subject \#4 - I have some parent support-the kids who have really committed themselves, they have a lot of support from their parents... When we go to competitions...we have to have parents come and help us...kind of chaperones, and they are always willing to come and help. They help us decorate for the concerts and that kind of stuff. They do stay involved when we have out of school time things... We do have a little bit of community support. That is growing as we perform for things, but generally __ does not have a whole lot of support for the arts. So, that is a struggle and we're working on it and dealing with it the best that we can... When they hear true singing, you know, from when they get into the higher grades, they don't appreciate it because it's not loud, they 
can't hear it as much, and you know, it's not the same kind of stuff that they hear all of the time so they really don't appreciate different genres of music. They just want to hear their one kind of music and that's it...so we really don't get a lot of support for the stuff that we should be teaching. (District E, Rural, Junior High, Conference CC, Assistant Director, $2^{\text {nd }}$ Year Teacher)

Subject \#24 - I do have parent and community support. Very active, very helpful support from many of my parents, at least from the more wealthy parents, because I live in a wealthy district. My low socio-economic group is not as active. I have parent volunteers for concerts and trips, and as far as chaperones, helping put concerts together, publicity, for our pop show they do scenery, help get props together and things like that. (District C, Suburban, Middle School, Conference CCC, Head Director, $3^{\text {rd }}$ Year Teacher)

Subject \#35 - Well, as a whole school environment I would say there is probably not a lot of community support. But we do have quite a few parents that are involved in the choir portion. If we are going on trips, they help chaperone the trips [and] they help us when we feed the kids... (District A, Urban, Junior High, Conference CCC, Assistant Director, $4^{\text {th }}$ Year Teacher)

Subject \#63 - We have a wonderful booster club that helps us out a great deal. They take care of payments, uniforms, fund raisers, etc. I would say the community tends to support the sports programs a little bit more than the music programs here. However, we always have packed houses for all of our concerts (although I think this is all of the parents). (District D, Suburban, High School, Conference AAAAA, Assistant, $2^{\text {nd }}$ Year Teacher)

Subject \#67 - I feel like I have pretty good parent support for my choir program -the parents here are very good about coming to concerts and being involved in fundraising, etc... (District B, Suburban, Middle School, Conference CC, Head Director, 3.5 Year Teacher)

Subject \#74 - When I arrived at this job, the booster club was already established and I get a lot of support from the booster club. Especially the senior parents are really involved. They take on a lot of responsibility, especially with fund raising for scholarships, helping out with the variety show we do once a year. (District D, Suburban, High School, Conference AAAA, Head Director, $5^{\text {th }}$ Year Teacher)

Subject \#84 - We have a very good parent support system. Our boosters are very supportive and very active and they are major players in the community so they are good at getting the community involved - kind of a go-between between the school and the community. (District C, Suburban, High School, AAAA, Assistant Director, $5^{\text {th }}$ Year Teacher) 
In summary, interviewees defined parent support as having parents who: serve as chaperones on trips; attend concerts; arrange publicity; decorate for concerts; provide food for students; assist with uniforms; and support the choir in fundraising activities. Community support was characterized by interviewees as attendance at choir concerts.

\section{Methods of Professional Assistance}

Methods of assistance that early career teachers ranked the highest were not reported to be available to all teachers. Colleagues in the music field tied for the first position of importance to teachers, yet were available to $93.1 \%$ of early career teachers. Music workshops or conferences were also ranked first but only $81.6 \%$ of the teachers reported that it was made available to them.

Administrators tended to give the highest ranking to methods of assistance in which they were an active participant. Principals ranked accessibility of administrator first, and $90.8 \%$ of teachers reported it was provided. However, while principals ranked administrative assistance with classroom management second, only $48.2 \%$ of early career teachers reported having classroom management assistance.

\section{$\underline{\text { Attrition and Retention }}$}

Twelve out of 87 respondents $(13.7 \%)$ indicated that they planned to leave the teaching profession. This overall attrition rate is slightly lower than the $20 \%$ rate of attrition reported by Killian and Baker (2004) in study of new members to the Texas Music Educators Association. Perhaps the lower overall rate of attrition reported in this study is due to the small number of subjects and more limited geographical area. 
However, if attrition rate is viewed in terms of Years of Teaching Experience, the percentages are more in keeping with the Killian and Baker findings (See Table 5.1). Among the teachers with 2 years of teaching experience, $22.2 \%$ intended to leave the teaching profession, which is higher than the $20 \%$ attrition rate found in the Killian and Baker study. Additionally, teachers with 1 to 1.5 years of teaching experience had an $18.7 \%$ intention rate of leaving teaching, which is close to the $20 \%$ attrition rate. Therefore, while this study's overall intention rate was $13.7 \%$, the rate varied from high $(22.2 \%)$ to low $(5.0 \%)$ depending on the years of teaching experience.

These reports of intended attrition are in keeping with the trend reported by Norton (1999) which found that 25\% of teachers leave after one year. Additional studies indicate that as many as $40 \%$ of teachers will leave after two years of teaching (Karge, 1993; Lucksinger, 200: Sclan, 1993).

Table 5.1: Rate of early career teacher intention to leave the teaching profession by Years of Teaching Experience

\begin{tabular}{lccc} 
Years of Experience & $n$ & $\begin{array}{c}\text { Teachers intending } \\
\text { to leave }\end{array}$ & Percentage \\
\hline 1 to 1.5 & 16 & 3 & 18.7 \\
2 & 18 & 4 & 22.2 \\
3 to 3.5 & 20 & 1 & 5.0 \\
4 & 13 & 2 & 15.3 \\
5 & 20 & 1 & 5.0
\end{tabular}


Division of subjects into subgroups helped characterize early career teachers who plan to leave the teaching profession. In terms of geographical location, 4 teachers (33.3\%) in Region 20 reported their intention to leave teaching, compared to only 1 teacher (8.3\%) in Region 24. Perhaps this can be explained by the large number of urban schools in Region 20 and the large number of suburban schools in Region 24.

Teachers $(8.3 \%)$ in the smallest school districts, District E - I, were the least likely to leave the profession. This can perhaps be explained by the fact that there are fewer job opportunities in the areas where small school districts are located.

Teachers in urban schools (58.3\%) reported a higher rate of intention to leave the teaching profession than teachers in suburban and rural schools. This is consistent with studies by Delgado (1999) and Quartz (2003) who report that attrition rates are higher in high-poverty and urban schools. Ingersoll (2001) states that beginning teachers in urban districts leave at higher rates than their counterparts in suburban schools. Ingersoll adds that teachers in high-poverty schools are 50\% more likely to leave the teaching the profession than those in low-poverty schools. Hill (2003) cites studies that show that 30 to $50 \%$ of beginning teachers who teach in urban schools leave within the first three years.

Early career teachers who teach in junior high schools (16.6\%) reported a lower rate of intention to leave teaching than did those in high schools and middle schools. It follows that $0 \%$ of teachers in Conference BB - BBB (designation for junior high schools) intended to leave the teaching profession. 
Early career teachers who have taught at their present school for 1 to 1.5 years (58.3\%) reported the highest rate of intention to leave the teaching profession. Perhaps this is because teachers have changed schools in an effort to give teaching a second chance and have found that the situation was no better in the new school. It is also interesting to note that $0 \%$ of teachers who were in their $4^{\text {th }}$ or $5^{\text {th }}$ year at their present school intended to leave teaching. This can perhaps be explained by the fact that they have remained in the school in which they began teaching because they were so satisfied. Otherwise, it might be assumed that they would have left to try a different school setting.

In terms of Position on Choral Staff, assistant directors (58.3\%) showed a higher intention of leaving than did head directors. Additionally, early career teachers who serve in a school with $1.5-3$ people on the choral staff (75.0\%) indicated a much higher rate of intention to leave than did teachers who teach alone. This phenomenon is puzzling in that schools with multiple people on staff are more readily available to provide mentoring for early career teachers.

Early career teachers intending to leave the teaching profession were provided with a checklist of reasons for leaving. Six factors were selected by $41.6 \%$ of the teachers. The first factor, lack of student motivation, is cited in numerous studies as a reason for leaving the teaching profession (Ingersoll, 2001; Ingersoll \& Smith, 2003; Jorissen, 2002). Additional researchers agree that having classes of unmotivated students is a major factor in an early career teacher's decision to defect (DePaul, 2000; Gordon, 1991; Halford, 1999; Huling-Austin, 1986; Kestner, 1994; Peck, 2002; Veenman, 1984; Yee, 1990). 
Two other factors for leaving the teaching profession include pursuing another music career and attending graduate school in music. Some choral directors may choose to enter a performance venue. Those attending graduate school may be preparing to either study performance or be gaining credentials to teach in a higher level of education.

Job stress was also named as a factor leading to teacher attrition. Research indicates that a number of causes can lead to teacher job stress including working conditions (Heyns, 1988; Hunt \& Carroll, 2002; Lucksinger, 2000), as well as being expected to have skills that can only be gained through experience (Huberman, 1989).

Lack of discipline is another key factor selected by early career teachers who intend to leave the teaching profession. Numerous studies have cited student discipline problems as a cause for the high rate of teacher attrition (Eggen, 2002; Ingersoll, 2002; Langdon, 1996; Madsen \& Madsen, 1998; Norton, 199; Norton \& Kelly, 1997; Veenman, 1984).

Early career teachers intending to stay in the teaching profession were given a checklist of reasons for remaining in teaching. The most frequent response was support of other teachers. In order to clarify specifically what support from faculty members involved, interviewees were asked about support of other teachers in their schools. Some of their responses follow:

Subject \#4 - When it does not require something that is out of their way, yes, they are very supportive. When it is concerts, there's a few that are already musically inclined and understand where we're coming from, and understand music and they do come and support, or if they have a student that they would particularly like to see succeed, then they come, but very seldom do they come outside of school time. But if it's something during the day, then they will support us. (District E, Rural, Junior High, Conference CC, Assistant Director, $2^{\text {nd }}$ Year Teacher) 
Subject \#24 - I do have a lot of support from faculty members. I have a lot of faculty members who volunteer in all areas to help out with shows and they help with getting my kids to extra rehearsals and if they need extra tutoring before contest and things like that. (District C, Suburban, Middle School, Conference CCC, Head Director, $3^{\text {rd }}$ Year Teacher)

Subject \#35 - I would say some do and some don't. They allow children to come to us during advisory classes so we can work with our mixed group. They help us out any way that they can. If we need to know the grades they are willing to give us the grades...But there are quite a few that don't think we do anything. In other words, just music teachers, just a place for the kids to run around and sing. .. I mean they know we go to contest and they know that we get Sweepstakes, but they don't understand what all of that means. They think anyone can go and get whatever. They just don't understand. (District A, Urban, Junior High, Conference CCC, Assistant Director, $4^{\text {th }}$ Year Teacher)

Subject \#67 - The other faculty members are somewhat supportive of the program, However, there is one area that I would like to see improve - I would love to see more faculty members attend our concerts. (District B, Suburban, Middle School, Conference CC, Head Director, 3.5 Year Teacher)

Subject \#74 - Yes, very much so. In a school as large as , the turnover in other areas has been a concern. Knowing teachers in areas other than fine arts has been a challenge. At the beginning of the year-who is that person-I don't know who they are. But especially in the fine arts the teachers have been very supportive. (District D, Suburban, High School, Conference AAAA, Head Director, $5^{\text {th }}$ Year Teacher)

Subject \#84 - The other fine arts teachers are supportive. The academic teachers-I think we are trying to bridge the gap between the two, because there are few of them that do not understand the importance of the fine arts and that we are actually assisting them in what they do in the classroom. But the principal is kind of helping to smooth that transition. (District C, Suburban, High School, AAAA, Assistant Director, $5^{\text {th }}$ Year Teacher)

Support of other faculty members was interpreted by interviewees to mean

attendance and assistance with concerts, allowing students to go to the Choir Room for extra rehearsals, and providing grades for UIL eligibility. Fine arts faculty were reported as being the most supportive. Interviewees expressed dissatisfaction with other faculty 
members regarding a lack of understanding about choir curriculum, the importance of music education, and the partnership between music teachers and the rest of the faculty.

The second most frequent response given by early career teachers for intending to stay in the teaching profession was school environment. Interviewees were asked to explicate what is meant by either a positive or negative school environment. Their responses follow:

Subject \#4 - I think a lot of times our school, our district, kind of caters to the children and the parents' whims whether it is legitimate or not. They're kind of like, 'Oh, we'll do what you need us to do' and they sometimes do that at the expense of the teachers, so the kids get away with things that they shouldn't at all. We have a lot of low-income kids and so we have a lot of struggle with that. A lot of times you see that the kids come to school so they can get a meal. They don't care about their success. They are just there to survive. They are just in survival mode. And then there's the others, the select few, that are in the same situation as the others and are coming for a meal, but they kind of cling onto you because they feel that love from you, they feel that support, and they know that they can succeed because they are taking our word, you know, they are feeling it inside. They have a little more drive than the other kids. (District E, Rural, Junior High, Conference CC, Assistant Director, $2^{\text {nd }}$ Year Teacher)

Subject \#5 - It is borderline between negative and positive. There's a lot of unresolved issues and it's kind of at a place where they need to have some changes to move forward, so I sense a lot of hostility in the lounge and workroom. They feel like the rules continue to change. You know, they post dress code and then they come back two weeks later and say, 'Let's do it this way.' They tell us to document, document, send them to the office, send them to the office, or you will be held accountable and when you send them to the office the principal will turn around and send them back and say there is not a problem with the dress code. Those kinds of things. (District D, Suburban, High School, Conference AAAA, Head Director, $4^{\text {th }}$ Year Teacher)

Subject \#16 - We have a great school environment. All the kids are pretty wellbehaved. There's few, but it's nothing an inner-city school or anything like that. (District D, Suburban, High School, Conference AAAA, Assistant Director, $1^{\text {st }}$ Year Teacher)

Subject \#24 - This year it has been very good...A good community atmosphere, the kids are well-disciplined and on-task...I would attribute it to a discipline plan 
that was put together by the teachers themselves, and we had a lot of discussion about what we felt needed to be done over the summer and changes that were made from last year and it has helped a lot. (District C, Suburban, Middle School, Conference CCC, Head Director, $3^{\text {rd }}$ Year Teacher)

Subject \#35 - Positive school environment...A lot of supportive teachers. There is just a welcoming feeling that you get when you walk inside of our school. And there is a lot of PTA involvement. There are always parents up there helping behind the desk and if there is ever anything you need you can ask the PTA. There are a lot of other schools that are built the exact same way as is and walking into the other schools that are built just the same way I just don't feel the warmth that I felt the first time I walked into . I had the opportunity to choose where I wanted to go work and that was one of the reasons I chose to go to , because of the warm feeling, the atmosphere that school provides. (District A, Urban, Junior High, Conference CCC, Assistant Director, $4^{\text {th }}$ Year Teacher)

Subject \#67 - Personally, I feel respected on campus by the kids and other teachers, and I have strong administrative support. Also, I think that in general, my school tries to offer a positive environment for everyone who is here students and teachers alike. I have never seen a staff that so obviously is interested in educating the 'whole child.' The kids here have many opportunities to get involved and be a part of something... The teachers as a whole are open and available for students before and after school. Also, it is obvious that the administration here has a vested interest in trying to improve student achievement and also in increasing parent/community ties to the school... Also, as a staff, there are many get-togethers and social opportunities for teachers and staff members to get to know one another. Last year, my principal wrote a murder mystery dinner game for the whole staff! (That's just one example.) Overall, this is a really positive place to be. (District B, Suburban, Middle School, Conference CC, Head Director, 3.5 Year Teacher)

Subject \#74 - A relaxed and a tight ship all at the same time. I don't feel-I guess this is going back to administration again, I don't feel like it is micromanaged. I feel like if things are going well the administration knows to step back and let the teachers do what they need to do. The discipline is carried out very swiftly and good. Parental contact is made at many levels - teachers and administrators. (District D, Suburban, High School, Conference AAAA, Head Director, $5^{\text {th }}$ Year Teacher)

Subject \#84 - I think it is a positive environment. I think there is more camaraderie this year because of the new principal. He makes sure that all areas_-academics, athletics and the fine arts — are equally supported and equally recognized and that everyone feels that they are working towards a common goal and everything they do is important, no matter if it is the head coach of the 
football team or cosmetology class. Everyone is supported. (District C, Suburban, High School, AAAA, Assistant Director, $5^{\text {th }}$ Year Teacher)

School environment was defined in a number of different ways by interviewees. Many responses indicated that administrators played a major role in school environment. A positive environment was described by one subject as a school in which the administration supported and recognized all areas—academics, arts, and athleticsequally and teachers felt they had a common goal. Another interviewee felt that the positive environment in his school was due to his administrator allowing teachers to make decisions and not being a micromanager. One teacher described the environment in her school as being "hostile" because the administration is constantly changing the rules. Another teacher claimed her school environment was negative because the administrators supported the parents and students rather than the teachers.

The definition of school environment by interviewees was also student-centered. Issues such as student motivation, student discipline, and student involvement were mentioned frequently by the subjects. A criterion of a positive environment provided by one teacher was good student/teacher relationships. Parental involvement was also mentioned as a contributing factor to a positive environment.

Thus, school environment was deemed to be either positive or negative by interviewees largely based on relationships between administrators and teachers and student behavior. 


\section{Teacher Intention to Stay or Leave Current Teaching Position}

Seventeen out of 87 respondents $(19.5 \%)$ indicated that they planned to leave the their current teaching position. An examination of various subgroups helps identify early career teachers who plan to leave their current teaching position. In terms of geographical location, 5 teachers $(29.4 \%)$ in Region 20 reported their intention to leave their current teaching position. This is consistent with the fact that Region 20 also had the largest number of teachers (4) intending to leave the profession. In addition, Region 20 had the lowest job satisfaction rating (3.8) of the 5 five regions.

Teachers $(29.4 \%)$ in the largest school district category, District A, were the most likely to leave their current teaching position. This percentage is inconsistent with District A's job satisfaction rating of 4.2, the highest of the 5 regions. Teachers $(23.5 \%)$ in District D schools were the second most likely to leave their current teaching position. This percentage is in keeping with the fact that District $\mathrm{D}$ also tied for the largest number of teachers (3) intending to leave the profession. Additionally, teachers in District D schools had the lowest job satisfaction rating (3.7) of the 5 categories of Districts.

Eleven out of the 17 early career teachers $(64.7 \%)$ intending to change schools taught in suburban schools. This is highly inconsistent with the suburban rating of job satisfaction (4.2), as well as the small number of suburban teachers planning to leave the teaching profession (4).

Early career teachers who teach in middle schools (52.9\%) reported the highest rate of intention to leave their present teaching assignment among the three School Levels. This percentage is consistent with the fact that middle school teachers tied with 
high school teachers $(41.6 \%)$ as having the highest rate of intention to leave the teaching profession. However, the middle school job satisfaction rating of 4.1 belies the high rate of intention to change schools.

Among the five Conferences, Conference CCC had the highest number of teachers (7) intending to leave their present teaching assignment. This is in keeping with the fact that Conference CCC teachers tied for the lowest job satisfaction rating (4.0). Conference $\mathrm{CC}$ followed closely behind with 5 teachers intending to change schools. This is in keeping with the fact that Conference CC had the largest number of teachers planning to leave the teaching profession (5). However, the job satisfaction rating of Conference CC teachers was 4.1, which is consistent with the overall mean.

In terms of Years of Teaching Experience, teachers who had 1 to 1.5 years of experience reported the highest rate of intention to change schools $(29.4 \%)$. Teachers in this category ranked second in terms of intention to leave the teaching profession $(25.0 \%)$ and had a job satisfaction rating of 4.0 , below the overall mean of 4.1 . It is interesting to note that teachers with 4 years of teaching experience had a much lower rate of job satisfaction, 3.6, yet did not rank high in their intention to leave the teaching profession $(16.6 \%)$ or to leave their current teaching position $(17.6 \%)$.

Teachers with 1 to 1.5 years and 3 years at their present school tied for highest percentage of intention to change teaching assignments (35.2\%). Teachers with 1 to 1.5 years of experience also ranked first in intention to leave the teaching profession $(58.3 \%)$ and had a job satisfaction ranking of 4.0, below the overall mean of 4.1 The high percentage of intention to change schools for teachers with 3 years at their present school 
was not consistent with their low intention rate of leaving the teaching profession $(16.6 \%)$ nor their job satisfaction rating of 4.2 , which is above the overall mean of 4.1 .

In terms of Position on Choral Staff, head directors (58.8\%) showed a higher intention of leaving their present teaching position than did assistant directors This is consistent with the 4.0 job satisfaction rating provided by head directors, compared to the assistant director rating of 4.2. Additionally, early career teachers who are the sole person on the choral staff $(64.7 \%)$ indicated a much higher rate of intention to leave their present teaching assignment than did teachers who teach with 1.5 to 3 people on staff. This is consistent with the job satisfaction rating of 4.0 for teachers at schools with 1 person on staff, compared to the rating of 4.3 for people with 1.5 to 3 people on staff.

Early career teachers intending to change schools were provided a checklist of reasons. Three of the most frequently selected factors-job stress, lack of student motivation, and lack of student discipline-were identical to the factors that appeared at the top of the list of reasons for teachers leaving the profession. Perhaps the teachers who intend to change schools feel that these factors might be reduced or eliminated in a different school environment. On the other hand, perhaps the teachers who are leaving because of these factors have either tried changing schools and found it ineffectual or simply were too discouraged to try another school.

\section{$\underline{\text { Role of Administrators }}$}

Administrative support was a factor selected by $41.3 \%$ of early career teachers as affecting their job satisfaction. Interviewees were asked to describe the nature of 
administrative support they receive in their school. Some of the interviewees' responses

are listed below:

Subject \#4 - We do have quite a bit of support. They understand that it helps the kids...We have really bad scheduling. This is just my second year, but last year, we had really, really bad scheduling, and the end of last year (last year I was very successful at UIL Concert/Sightreading).... and so I [said] I would really rather have this schedule, and I would really rather do this and they said, "We'll do what we can" and they said they would help us out a lot. I mean they are backed up against the wall with some things but as much as they can do, they usually help us. But we got our own room this year. We had to share it with the band last year and they worked it around where we could have our own room. (District E, Rural, Junior High, Conference CC, Assistant Director, $2^{\text {nd }}$ Year Teacher)

Subject \#16 - We have great administrative support. He's always there for us to go in and talk to if we need to have a chat. He really encourages the fine arts by allowing us to do multiple musicals and go on trips. (District D, Suburban, High School, Conference AAAA, Assistant Director, $1^{\text {st }}$ Year Teacher)

Subject \#24 - I have had concerts where I have not had an administrator show up at all. They could support...in assisting getting equipment and scheduling.

Scheduling is a big thing. The last couple of years the scheduling has not been conducive to my program. I would say scheduling is the biggest thing. They have cut periods of choir and they have set choir against other large electives like athletics and band which makes it impossible for kids to make choices that they don't want to make. (District C, Suburban, Middle School, Conference CCC, Head Director, $3^{\text {rd }}$ Year Teacher)

Subject \#35 - They pretty much are behind us in anything that we choose to do, especially this year. We don't actually get administrative support at our concerts. We used to. We used to always have some type of administrator at our concerts but this year we haven't had one come yet. But as far as giving us the schedule we wanted or if we needed to go somewhere, or that kind of thing, they are behind us going and they give us support that way. (District A, Urban, Junior High, Conference CCC, Assistant Director, $4^{\text {th }}$ Year Teacher)

Subject \#67 - My principal is EXTREMELY SUPPORTIVE!!! He is willing to help out in any way possible - in the past, he has video-taped concerts, chaperoned UIL trips, driven the bus on choir field trips, and he helps set up and break down my choral shell before and after every concert. I am very lucky to work with someone who is so supportive of the choir. (District B, Suburban, Middle School, Conference CC, Head Director, 3.5 Year Teacher) 
Subject \#74 - Always a presence, whether it is the principal or assistant principal, always a presence at events, school-wide, not just in choir, but feel very supported at concerts or any presentation that we do throughout the year. (District D, Suburban, High School, Conference AAAA, Head Director, $5^{\text {th }}$ Year Teacher)

Subject \#84 - We have excellent administrative support... They are supportive monetarily, they are flexible with schedules and letting kids out of class and giving them opportunities to travel. And they attend performances and let the kids know, they are visible to the kids and let them know that they are there and that they are supporting their program. (District C, Suburban, High School, Conference AAAA, Assistant Director, $5 \mathrm{t}^{\mathrm{h}}$ Year Teacher)

Subject \#5 -Right now, my current year, I am having a lot of difficulty with parent support because the previous situation they were always were allowed to make a lot of decisions for the director and so I have been complained about to my principal several times and the principal supported the parent in both situations. He didn't listen to my side or give me the professional courtesy of respecting my decision... Just in general when it comes to a parent and that administrator being out there in front of his administrator, that they are going to protect themselves, or at least this administrator is going to look out for himself rather than supporting the program and rather than supporting me. (District D, Suburban, High School, Conference AAAA, Head Director, $4^{\text {th }}$ Year Teacher)

Interviewees indicated that some of the primary ways administrators show support

for their choir program is by attending concerts and by allowing the teacher to have a schedule that maximizes their enrollment. Conversely, teachers stated that they felt lack of administrative support when principals failed to attend concerts and when their schedules eliminated potential choir members.

Additional responses regarding administrative support included provision of adequate facilities, equipment, and money and allowing students to take trips. Other interviewees mentioned the importance of the administrator being accessible and supporting the teacher when in conflict with a parent.

Administrators seemed to play an important role in teacher job satisfaction. The Spearman rank correlation procedure was conducted for each subgroup to determine the 
correlation between early career teachers' and principals' ratings of the value of various types of professional assistance. It is important to note that the subgroups that had a high level of agreement between early career teachers and their principals also reported relatively high levels of job satisfaction. The subgroups with significant positive correlation are shown in Table 5.2 below:

Table 5.2: Subgroup correlation between early career teachers and principals rating of methods of professional assistance and job satisfaction

\begin{tabular}{lcccc}
\hline Subgroup & $\mathrm{n}$ & $\mathrm{rs}$ & $\mathrm{p}$ & $\begin{array}{c}\text { Job Satisfaction } \\
\text { Mean }\end{array}$ \\
\hline Region 3 & 20 & .66 & .0008 & 4.2 \\
Region 5 & 27 & .57 & .005 & 4.1 \\
District A & 24 & .64 & .002 & 4.2 \\
District B & 21 & .69 & .0004 & 4.4 \\
District C & 25 & .54 & .01 & 4.0 \\
Suburban & 57 & .69 & .001 & 4.2 \\
Middle School & 42 & .56 & .01 & 4.1 \\
Conference CCC & 29 & .66 & .001 & 4.0 \\
1 to 1.5 years & & .53 & .008 & 4.0 \\
teaching experience & 16 & & & \\
\hline
\end{tabular}

On the other hand, rural teachers $(n=5)$ who had a score of $r s=-.005 ; p=.98$, indicating a non-significant negative correlation, had a job satisfaction ranking of 3.8 . Thus, it might be concluded that the greater amount of agreement between teachers and principals regarding the value of various methods of professional assistance, the greater 
the job satisfaction. Conversely, the lesser amount of agreement between teachers and principals, the lower the job satisfaction.

Inadequate administrative support is one of the primary reasons early career teachers in this study gave for defecting from teaching. National survey data indicate that teachers' decisions to remain in teaching are closely associated with the teachers' perceptions about administrative support (Darling-Hammond, 1997). Beginning teachers look to their principals as their primary source of guidance, instructional leadership, and support (Brock \& Grady, 1998; Colley, 2002). Chapman (1984) adds that administrators can influence attrition by "shaping the tone and quality of a new teacher's first teaching experience" (p. 655).

An additional factor that could possibly attribute to an early career teacher's intention to leave the teaching profession is the level of agreement between teacher and principal regarding their philosophy of music education. A Spearman correlation procedure comparing early career teachers' and their principals' views regarding music education revealed that only 3 out of the 12 teachers planning to leave the profession had a significant positive correlation with their principals' philosophy of music education. Perhaps a difference in philosophical views could cause teachers to leave teaching.

In the same way, a comparison of views of the value of methods of professional assistance between early career teachers who intend to leave teaching and their principals showed that only 3 out of the 12 teachers had a significant positive correlation. This indicates that $75 \%$ of the teachers and their principals did not have an agreement 
regarding professional assistance. Perhaps this difference could contribute to the teachers' decisions to leave the teaching profession.

Conversely, administrative support was selected by $48.6 \%$ of the teachers as a reason for staying in the teaching profession. This percentage is consistent with numerous studies indicating that administrative support has a strong influence on a teacher's decision to remain in the profession (Betancourt-Smith, Inman, \& Marlow, 1994; Billingsley, 1993; Bobbitt, Faupel, \& Burns, 1991; Brewster \& Railsback, 2001; Chitton \& Sistrunk, 1990; Ingeroll, 1999; Johnson \& Birkeland, 2003a; Metzke, 1988; Peck, 2002). A study by Ingersoll (2001) indicates that turnover rates are considerably lower in schools that provide strong administrative support to teachers.

Data analysis indicates that among the 17 teachers who intended to change schools, there was not one teacher who showed a significant positive correlation with their principal regarding philosophy of music education or the value of methods of professional assistance. Perhaps this lack of agreement on critical issues has an effect on the teachers' decisions to leave their current teaching position.

Administrators do appear to play an important role in teacher job satisfaction, retention and attrition. Data also indicate that teacher and administrator perception of key issues surrounding music education and methods of support are dissimilar. Perhaps the current rate of music teacher attrition could be averted by making administrators aware of the vital role they play in teacher job satisfaction and by educating them regarding what methods of assistance are of the greatest value to early career teachers. 


\section{Suggestions for Further Study}

This study focused on secondary choral directors in five geographical regions in North Texas. To make this study more comprehensive, a larger population of secondary music teachers from band, choir and orchestra should be surveyed. Generalizations of these results to other populations should be made with caution due to the limited scope of the study.

It would be interesting to revisit the teachers included in this study five years from now to determine if they are still teaching and whether their view of the variables identified in this study change based on years of teaching experience. It might also be beneficial to compare teacher perceptions of variables influencing satisfaction and retention between early career music teachers in the secondary and elementary levels.

Results from this study emphasize the importance of parent and community support on teacher job satisfaction. Perhaps a further examination of parent and community support would help to better define the nature and value of this type of support. In the same way, since support of faculty members was a major factor in teacher retention, perhaps a closer investigation of the attributes of this type of support would contribute to a better understanding of this phenomenon. A paucity of research is available regarding these two methods of support.

Finally, this study centered on early career teachers currently working in the classroom. Future research on new teacher job satisfaction, attrition, and retention should also focus on secondary music teachers who quit the teaching profession during their first five years. Specifically, those individuals could provide interesting perspectives about 
variables influencing their decision to leave the profession. Their insights could provide valuable information for secondary principals working to create environments that enhance early career teacher satisfaction and retention. 


\section{REFERENCES}

Anderman, E. M., Belzer, S., \& Smith, J. (1991, April). Teacher commitment and job satisfaction: The role of school culture and principal leadership. Paper presented at the annual meeting of the American Educational Research Association, Chicago, IL. (ERIC Document Reproduction Service No. ED 375497).

Anderson, N. (2000). Recruiting for the profession. Teaching Music, 8(2), 24-31.

Ankey, M. \& Zanville, H. (2002). Teacher attrition/retention study. Retrieved August 13, 2004 from Oregon Quality Assurance in Teaching Web site: http://www.ous.edu/aca/TEpdf/attrition7-02.pdf

Asmus, E. (1999). The increasing demand for music teachers. Journal of Music Teacher Education, 8(2), 5-6.

Bergee, M. J. \& Demorest, S. M. (2003). Developing tomorrow's music teachers today. Music Educators Journal, 89(4), 17-20.

Berry, B. (2004). Recruiting and retaining "highly qualified teachers" for hard-to-staff schools. National Association of Secondary School Principals, 87(638), pp. 5-27.

Betancourt-Smith, M., Inman, D., \& Marlow, L. (1994, November). Professional attrition: An examination of minority and nonminority teachers at-risk. Paper presented at the annual meeting of the Mid-South Educational Research Association, Nashville, TN. (ERIC Document Reproduction Service No. ED 388639).

Billingsley, B. S. (1993). Teacher retention and attrition in special and general education: A critical review of the literature. The Journal of Special Education, 27, 137-174.

Billingsley, B. S. \& Cross, L. H. (1992). Predictors of commitment, job satisfaction and intent to stay in teaching: A comparison of general and special educators. The Journal of Special Education, 25, 453-471.

Bobbitt, S. A., Paupel, E., \& Burns, S. (1991). Characteristics of stayers, movers, and leavers: Results from the Teacher Follow-up Survey: 1988-89. Washington, DC: National Center for Education Statistics. 
Boe, E. E., Bobbitt, S. A., \& Cook, L. H. (1997). Whither didst thou go? Retention, reassignment, migration, and attrition of special and general education teachers from a national perspective. Journal of Special Education, 30(4), 371-389.

Bogler, R. (1999, April). Reassessing the behavior of principals as a multiple factor in teachers' job satisfaction. Paper presented at the annual meeting of the American Educational Research Association, Montreal, Quebec, Canada. (ERIC Document Reproduction Service No. ED 432800).

Bogler, R. (2001). The influence of leadership style on teacher job satisfaction. Educational Administration Quarterly, 37(5), 662-683.

Borg, M. G. \& Riding, R. J. (1991). Occupational stress and satisfaction in teaching. British Educational Research Journal, 17(3), 263-281.

Brewster, C. \& Railsback, J. (2001). Supporting beginning teachers: How administrators, teachers and policymakers can help new teachers succeed. Portland, OR: Northwest Regional Educational Laboratory.

Brock, B. L. \& Grady, M. L. (1998). Beginning teacher induction programs: The role of the principal. Clearing House, 71(3), 179-183.

Byrne, B. M. (1992). Investigating causal links to burnout for elementary, intermediate, and secondary teachers. Ontario, Canada. (ERIC Document Reproduction Service No. ED 397060).

Carroll, S., Reichardt, R., \& Guarino, C. (2000). The distribution of teachers among California's school districts and schools. Santa Monica, CA: RAND.

Certo, J. L. \& Fox, J. E. (2002). Retaining quality teachers. High School Journal, 86(1), 57-75.

Chapman, D. W. (1983). Career satisfaction of teachers. Educational Research Quarterly, 7(3), 40-50.

Chapman, D. W. (1984). Teacher retention: The test of a model. American Educational Research Journal, 21(3), 645-658.

Chapman, D. W. \& Green, M. S. (1986). Teacher retention: A further examination. Journal of Educational Research, 7(5), 273-279.

Chapman, D. W. \& Hutcheson, S. M. (1982). Attrition from teaching careers: A discriminant analysis. American Educational Research Journal, 19(1), 93-105. 
Chapman, D. W., \& Lowther, M. A. (1982). Teachers' satisfaction with teaching. Journal of Educational Research, 75, 241-247.

Charters, W. W., Jr. (1970). Some factors affecting teachers survival rates in school districts. American Educational Research Journal, 7(1), 1-27.

Chittom, S. A. \& Sistrunk, W. E. (1990, November). The relationship between secondary teachers' job satisfaction and their perceptions of school climate. Paper presented at the annual meeting of the Mid-South Educational Research Association, New Orleans. (ERIC Document Reproduction Service Number ED 326567).

Colbert, J. \& Wolff, D. (1992). Surviving in urban schools. Journal of Teacher Education, 43, 193-199.

Colley, A. C. (2002). What can principals do about new teacher attrition? Principal, 8(4), 22-24.

Conway, C. M. (2003). An examination of district-sponsored beginning music teacher mentor practices. Journal of Research in Music Education, 51(1), 6-23.

Conway, C. M. (2002). Perceptions of beginning teachers, mentors, and administrators regarding preservice music teacher preparation. Journal of Research in Music Education, 50(1), 20-36.

Conway, C. M. (2001). What has research told us about the beginning music teacher? Journal of Music Teacher Education, 10(2), 14-22.

Conway, C., Krueger, P., Robinson, M., Haack, P., \& Smith, M. V. (2002). Beginning music teacher induction and mentor policies: A cross-state perspective. Arts Education Policy Review, 104(2), 9-17.

Curran, B., Abrahams, C., \& Manuel, J. (2000). Teacher supply and demand: Is there a shortage? Retrieved September 15, 2004 from National Governors Association Web site: http://www.nga.org/cda/files/000125TEACHERS.pdf

Daly, M. (2002, Fall). Fine-tuning a vision: New teacher training and retention in Oregon. Oregon Humanities, 20-23.

Darling-Hammond, L. (1997). Doing what matters most: Investing in quality teaching. New York: National Commission on Teaching and America's Future.

Darling-Hammond, L. (2003). Keeping good teachers: Why it matters what leaders can do. Educational Leadership, 60(8), 6-13. 
Darling-Hammond, L., Berry, B., \& Thoreson, A. (2001). Does teacher certification matter? Evaluating the evidence. Educational Evaluation and Policy Analysis, 23(1), 57-77.

Davis, G. W. (1988). Withdrawal from the teaching profession in Maricopa County, Arizona. (Unpublished doctoral dissertation, Arizona State University, Tempe, 1988). Dissertation Abstracts International, 49(05), 1010.

Deal, T. E., \& Chatman, R. M. (1989). Learning the ropes alone: Socializing new teachers. Action in Teacher Education, 11(1), 21-29.

Delgado, M. (1999). Lifesaving 101: How a veteran teacher can help a beginner. Educational Leadership, 56(8), 27-29.

DeLorenzo, L. C. (1992). The perceived problems of beginning music teachers. Bulletin of the Council of Research in Music Education, 113, 9-25.

Denzin, N. K. \& Lincoln, Y. S. (1998). Introduction: Entering the field of qualitative research. In N. K. Denzin \& Y. S. Lincoln (Eds.), Collecting and interpreting qualitative materials (pp. 1 - 34). Thousand Oaks, CA, London and New Delhi: Sage Publications.

DePaul, A. (2000). Survival guide for new teachers: How new teachers can work effectively with veteran teachers, parents, principals, and teacher educators. Washington, D.C.: United States Department of Education.

Dinham, S. (1994, September). Enhancing the quality of teacher satisfaction. Paper presented at the national conference of the Australian College of Education, Launceston, Tasmania, Australia. (ERIC Document Reproduction Service No. ED 380409).

Dinham, S., \& Scott, C. (1998). A three domain model of teacher and school executive career satisfaction. Journal of Educational Administration, 36(4), 362-378.

Eggen, B. (2002, February). Administrative accountability and the novice teacher. Paper presented at the annual meeting of the American Association of Colleges for Teacher Education, New York.

Ettorre, B. (1997). How are companies keeping the employees they want? Management Review, 86(5), 49-53. 
Firestone, W. A., Rosenblum, S., \& Webb, A. (1987). Building commitment among students and teachers: An exploratory study of ten urban high schools.

Philadelphia, PA: Research for Better Schools. (ERIC Document Reproduction Service No. ED 303535).

Fredricks, J. G. (2001). Why teachers leave. The Education Digest, 66(8), 46-48.

Fuller, E. \& Alexander, C. (2003). Teachers in Texas from different routes to teacher certification: Who are they, where do they teach, and how long do they teach? Austin, TX: Texas State Board for Educator Certification.

Gaede, O. (1978). Reality shock: A problem among first year teachers. Clearing House, 41, 405-409.

Geringer, J. (2000). In pursuit of quality teaching: Five key strategies for policymakers. Denver, CO: Education Commission of the States.

Gold, Y. (1996). Beginning teacher support: Attrition, mentoring, and induction. In J. Sikula, T. J. Buttery, \& E. Guyton (Eds.), Handbook of research on teacher education (pp. 548-594). New York: Simon \& Schuster Macmillan.

Gordon, S. P. (1991). How to help beginning teachers succeed. Alexandria, VA: Association for Supervision and Curriculum Development.

Grissmer, D. W. \& Kirby, S. N. (1987). Teacher attrition: The uphill climb to staff the nation's schools. Santa Monica, CA: RAND Corp.

Grissmer, D. W. \& Kirby, S. N. (1997). Teacher turnover and teacher quality. Teachers College Record, 99(1), 45-56.

Halford, J. M. (1998). Easing the way for new teachers. Educational Leadership, 55 (5), 33-36.

Halford, J. M. (1999). Policies to support new teachers. Educational Leadership, 56(8), 85.

Hall, B. W., Pearson, L. C., \& Carroll, D. (1992). Teachers' long-range teaching plans: A discriminant analysis. Journal of Educational Leadership, 85(4), 221-225.

Hamann, D. L. \& Daugherty, E. (1984). Teacher burnout: The cost of caring. Update, 2(3), 7-10. 
Hamann, D. L., Daugherty, E., \& Mills, C. R. (1987). An investigation of burnout assessment and potential job related variables among public school music educators. Psychology of Music, 14, 128-140.

Haycock, K. (1998). Good teaching matters: How well-qualified teachers can close the gap. Thinking K-16, 3(2), 3-14.

Haycock, K. (2000). No more settling for less. Thinking K-16, 4(1), 3-12.

Heller, W. H., Clay, R. \& Perkins, C. (1993). The relationship between teacher job satisfaction and principal leadership style. Journal of School Leadership, 3, 74-85.

Henke, R. R., Choy, S. P., Geis, S. \& Broughman, S. (1996). Schools and staffing in the United States: A statistical profile, 1993-94. Washington, DC: National Center for Education Statistics (NCES 96-124).

Henke, R. R., Chen, X., \& Geis, S. (2000). Progress through the teacher pipeline: 1992-93 college graduates and elementary/secondary school teaching as of 1997. Washington, DC: National Center for Education Statistics.

Heston, M. L., Didrick, C., Raschke, D., \& Whitehead, J. (1996). Job satisfaction and stress among band directors. Journal of Research in Music Education, 44(4), 319-327.

Heyns, B. (1988). Educational defectors: A first look at teacher attrition in the NLS-72. Educational Researcher, 17, 24-32.

Hill, W. L., Jr. (2003). The teacher shortage and policy. Music Educators Journal, 89(4), 6-7.

Hipp, K. A. \& Bredeson, P. V. (1995). Exploring connections between teacher efficacy and principal's behavior. Journal of School Leadership, 5(2), 136-150.

Holland, J. I. (1973). Making vocational choices: A theory of careers. Englewood Cliffs, NJ: Prentice Hall.

Hoffer, C. (1982). Work related attitudes and problems of Indiana music teachers. Psychology of Music, 10 (Special issue), 59-62.

Hope, W. C. (1999). Principals' orientation and induction activities as factors in teacher retention. Clearing House, 73(1), 54-56. 
Hoy, W. K. \& Miskel, C. G. (1991). Educational administration: Theory, research, and practice (4th ed.). New York: McGraw-Hill.

Huberman, M. (1989). The professional life cycle of teachers. Teachers College Record, 91(1), 31-57.

Huling-Austin, L. (1986). What can and cannot reasonably be expected from teacher induction programs. Journal of Teacher Education, 37(1), 2-5.

Huling-Austin, L. (1990). Teacher induction programs and internships. In W. R. Houston (Ed.), Handbook of Research on Teacher Education (pp. 535-548). Reston, VA: Association of Teacher Educators.

Hunt, J. \& Carroll, T. Unraveling the "teacher shortage" problem: Teacher retention is the key. Washington DC: National Commission on Teaching and America's Future.

Hylton, J. (1989). Ways to manage stress and avoid teacher burnout. Music Educators Journal, 75(6), 29-31.

Ingersoll, R. M. (1999). Teacher turnover, teacher shortages, and the organization of schools. Seattle, WA: Center for the Study of Teaching and Policy, University of Washington.

Ingersoll, R. M. (2001). Teacher turnover and teacher shortages: An organizational analysis. American Educational Research Journal, 38(3), 499-534.

Ingersoll, R. M. (2002). The teacher shortage: A case of wrong diagnosis and wrong prescription. NASSP Bulletin, 86(631), 16-31.

Ingersoll, R. M. (2003). Who controls teachers' work?: Power and accountability in America's schools. Cambridge, MA: Harvard University Press.

Ingersoll, R. M. \& Smith, T. M. (2003). The wrong solution to the teacher shortage. Educational Leadership, 60(8), 30-33.

Ingersoll, R. M. \& Smith, T. M. (2004). Do teacher induction and mentoring matter? National Association of Secondary School Principals Bulletin, 87(638), 28-40.

Ives, J. R. (2003). Should I stay or should I go? Factors in teacher retention. Dissertation Abstracts International, 42(02), 368.

Johnson, S. M. (1990). Teachers at work: Achieving success in our schools. New York: Basic Books. 
Johnson, S. M., \& Birkeland, S. (2003a). Pursuing a "sense of success": New teacher explain their career decisions. American Educational Research Journal, 40(3), 581-617.

Johnson, S. M. \& Birkeland, S. E. (2003b). The schools that teachers choose. Educational Leadership, 60(8), 20-24.

Jones, G. S. (1978). A descriptive study of problems encountered by first-year instrumental teachers in Oregon (Unpublished doctoral dissertation, University of Oregon, 1977). Dissertation Abstracts International, 39(01), 94.

Jorissen, K. T. (2002). 10 things a principal can do to retain teachers. Principal Leadership, 3(1), 48-54.

Kain, J. F., \& Singleton, K. (1996, May/June). Equality of educational opportunity revisited. New England Economic Review, 87-111.

Karge, B. D. (1993, April). Beginning teachers: In danger of attrition. Paper presented at the annual meeting of the American Educational Research Association, Atlanta, GA.

Keller, B. (2003). Question of teacher turnover sparks research interest. Education Week, 22(33), 8.

Kestner, J. L. (1994). New teacher induction: Findings of the research and implications for minority groups. Journal of Teacher Education, 45(1), 39-45.

Killian, J. N. \& Baker, V. D. (2004, April). The effect of personal and situational influences on the attrition and retention of music educators. Research Poster Session presented at the annual conference of Music Educators National Conference, Minneapolis, MN.

Kim, I., \& Loadman, W. (1994). Predicting teacher job satisfaction. Columbus: Ohio State University. (ERIC Document Reproduction Service Number ED 383707)

Kirby, S. N., \& Grissmer, D. W. (1993). Teacher attrition: Theory, evidence, and suggested policy options. Santa Monica, CA: RAND. (ERIC Document Reproduction Service Number ED 400240)

Krueger, P. J. (1999). New music teachers speak out on mentoring. Journal of Music Teacher Education, 8(2), 7-13.

Krueger, P. J. (2000). Beginning music teachers: Will they leave the profession? Update, 19(1), 22-26. 
Langdon, C. A. (1996). The third Phi Delta Kappa poll of teachers' attitudes toward the public schools. Phi Delta Kappan, 78(3), 244-250.

Lautzenheiser, T. (2001). Music teachers for the present and future. Teaching Music, 9(3), 37-40.

Little, J. W. (1996, April). Organizing schools for teacher learning. Paper presented at the annual meeting of the American Educational Research Association, New York.

Lortie, D. (1975). Schoolteacher: A sociological study. Chicago: University of Chicago.

Lucksinger, L. N. (2000). Teachers: Can we get them and keep them? The Delta Kappa Gamma Bulletin, 67(1), 11-15.

Madsen, C. K. \& Hancock, C. B. (2002). Support for music education: A case study of issues concerning teacher retention and attrition. Journal of Research in Music Education, 50(1), 6-19.

Madsen, C. K. \& Madsen, C. H. (1998). Teaching/Discipline: A positive approach for educational development. ( $4^{\text {th }}$ ed.). Raleigh, NC: Contemporary Publishing.

Mark, J. H. \& Anderson, B. D. (1978). Teacher survival rates: A current look. American Educational Research Journal, 15(3), 379-383.

Marlow, L., Inman, D., \& Betancourt-Smith, M. (1997). Beginning teachers: Are they still leaving the profession? Clearing House, 70(40), 211-214.

Mercer, R. J. \& Mercer, J. R. (1986). Band director burn-out: Strategies for survival. The Instrumentalist, 41(4), 44-52.

Merriam, S. B. (1998). Qualitative research and case study applications in education. San Francisco: Josey-Bass.

Merrow, J. (1999, October 6). The teacher shortage: Wrong diagnosis, phony cures. Education Week on the Web. Retrieved June 15, 2004 from the World Wide Web: http://www.edweek.org/ew/ewstory.cfm?slug=06merrow.h19\&keywords=shortage

Merrow, J. (2000). Brain drain. Teacher Magazine, 11(4), 50-51.

Merseth, K. K. (1992). First aid for first-year teachers. Phi Delta Kappan, 73(9), 678-683. 
Metzke, L. K. (1988). A study of the causes of teacher attrition in regular and special education in Wisconsin. Dissertation Abstracts International, 50(1), 42.

Millinger, C. S. (2004). Helping new teachers cope. Educational Leadership, 61(8), 66-69.

Murnane, R. J., Singer, J. D. \& Willett, J. B. (1988). The career paths of teachers: Implications for teacher supply and methodological lessons for research. Educational Researcher, 20, 22-30.

Murnane, R., Singer, J., Willett, J., Kemple, J., \& Olsen, R. (Eds.). (1991). Who will teach?: Policies that matter. Cambridge, MA: Harvard University.

Myton, D. V. (1984). Study on needs of beginning teachers. Salem, OR: Teacher Standards and Practices Commission. (ERIC Document Reproduction Service No. ED 275626).

Natale, J. (1993). Why teachers leave. Executive Educator, 15(7), 14-18.

National Center for Educational Statistics (1991). Characteristics of stayers, movers, and leavers: Results from the teacher follow-up survey: 1988-89.

Washington D. C.: U. S. Department of Education, Office of Educational Research and Improvement.

National Center for Educational Statistics (1997). Job satisfaction among America's teachers: Effects of workplace conditions, background, characteristics, and teacher compensation. Washington D. C.: U. S. Department of Education, Office of Educational Research and Improvement.

Norton, M. S. (1999). Teacher retention: Reducing costly teacher turnover. Contemporary Education, 70(3), 52-55.

Odell, S. J. \& Ferraro, D. P. (1992). Teacher mentoring and teacher retention. Journal of Teacher Education, 43(4), 200-204.

Peck, B. J. (2002). A high school principal's challenge: Toward work environments that enhance new teacher satisfaction and retention (Doctoral dissertation, University of Wisconsin at Madison, 2002). Dissertation Abstracts International, 63(11), 3807.

Pedhazur. E. J. \& Schmelkin, P. L. (1991). Measurement, design, and analysis: An integrated approach. Hillsdale, NJ: Lawrence Erlbaum Associates.

Ponessa, J. (1996). High teacher attrition grabs attention in North Carolina. Education Week, 15(39), 3. 
Ponick, F., Keathing, A., Pontiff, E., \& Wilcox, E. (2003). Help wanted! Teaching Music, 11(1), 24-29.

Quartz, K. H. (2003). “Too angry to leave:” Supporting new teachers' commitment to transform urban schools. Journal of Teacher Education, 54(2), 99-111.

Renard, L. (2003). Setting new teachers up for failure...or success. Educational Leadership, 60(8), 62-64.

Rinehart, J. S., Short, P. M>, Short, R. J. \& Eckley, M. (1988) Teacher empowerment and principal leadership: Understanding the influence process. Educational Administration Quarterly, 34, 630-649.

Scheib, J. W. (2002). Roles, expectations, and tension in the professional life of the school music teacher: A collective case study. (Doctoral dissertation, University of Wisconsin - Madison, 2002). Dissertation Abstracts International, 63(04), 1286.

Scheib, J. W. (2003). Role stress in the professional life of the school music teacher: A collective case study. Journal of Research in Music Education, 51(2), 124-136.

Schlecty, P. C. \& Vance, V. S. (1981). Do academically able teachers leave education? The North Carolina case. Phi Delta Kappan, 63(2), 105-112.

Schlechty, P. C. \& Vance, V. S. (1983). Recruitment, selection and retention: The shape of the teaching force. Elementary School Journal, 83(4), 469-487.

Schloss, P. J. \& Smith, M. A. (1999). Conducting research. New Jersey: Prentice-Hall.

Sclan, E. M. (1993). The effect of perceived workplace conditions on beginning teachers' work commitment, career choice commitment, and planned retention. Dissertation Abstracts International, 54(08), 2989.

Scott, L. D. (1995). Successful beginning teachers: A developmental model of support and assessment. Teacher Education Quarterly, 22(4), 93-105.

Shann, M. H. (1998). Professional commitment and satisfaction among teachers in urban middle schools. Journal of Educational Research, 92(2), 67-73.

Shen, J. (1997a). How to reduce teacher attrition in public schools: Policy implications from a national study. Educational Horizons, 76, 33-39.

Shen, J. (1997b). Teacher retention and attrition in public schools: Evidence from SASS91. Journal of Educational Research, 91(2), 81-88. 
Shin, H. S. \& Reyes, P. (1995). Teacher commitment and job satisfaction: A causal analysis. Journal of School Leadership, 5(1), 2-39.

Snapshot 2002. Texas Education Agency. Retrieved September 29, 2004 from the World Wide Web:

http://www.tea.state.tx.us/perfreport/snapshot/2002/distsize.html

State Board for Educator Certification On-Line. Retrieved August 8, 2004 from the World Wide Web:

http://www.sbec.state.tx.us./SBECOnline/certinfo/becometeacher.asp

Stubblefield, P. (1984). The relationship between stress, job satisfaction, and teaching assignments among music educators in the state of Michigan. Dissertation Abstracts International, 45(3), 782. (UMI No. 8407245).

Taylor, D. L. \& Tashakkori, A. (1994). Predicting teachers' sense of efficacy and job satisfaction using school climate and participatory decision making. Paper presented at the annual meeting of the Southwest Research Association, San Antonio, TX.

Teacher shortage at critical level. (2003). Teaching Music, 11(3), 12.

Texas Center for Educational research. (2000). The cost of teacher turnover. Austin, TX: Texas State Board for Teacher Certification.

Thompson, K. (1988, April). The responsibilities and needs of beginning music teachers. Paper presented at MENC's National Biennial In-Service Conference, Indianapolis, IN.

Ulriksen, J. J. (1996). Perceptions of secondary school teachers and principals concerning factors related to job satisfaction and job dissatisfaction (Doctoral dissertation, University of Southern California, 1996). Dissertation Abstracts International, 58(01), 127.

Veenman, S. (1984). Perceived problems of beginning teachers. Review of Educational Research, 54(2), 143-178.

Weiss, E. M. \& Weiss, S. G. (1999). Beginning teacher induction. Washington, D.C.: ERIC Clearinghouse on Teaching and Teacher Education. (ERIC Document Reproduction Service No. ED436487)

Wells, D. L. (1993). Factors affecting teachers' commitment to stay in teaching: A causal model. Dissertation Abstracts International, 54(12), 4330. 
Westfall, J. E. (2003). Relationship marketing in educational administration: An empirical study. Dissertation Abstracts International, 64(01), 223.

Whitener, S. D., Gruber, K. J., Lynch, H., Tingos, K., Perona, M. \& Fondelier, S. (1997). Characteristics of stayers, movers, and leavers: Results from the teacher followup survey: 1994-95 (NCES 97-450). Washington, DC: National Center for Education Statistics.

Wong, H. K. (2004). Induction programs that keep new teachers teaching and improving. National Association of Secondary School Principals Bulletin, 87(638), 5-27.

Yee, S. (1990). Careers in the classroom: When teaching is more than a job. New York: Teachers College.

2004 - 2005 Constitution and Contest Rules. University Interscholastic League. Retrieved February 2, 2005 from the World Wide Web: http://www.uil.utexas.edu/admin/04-05C\&CR/index.html 
APPENDIX A

THE QUESTIONNAIRE 


\section{MUSIC EDUCATION QUESTIONNAIRE}

Please react to each of the following statements by placing an $\mathbf{X}$ next to the appropriate response.

1. Music plays an integral part in the school's curriculum. Strongly Disagree Disagree Neither Agree nor Disagree Agree Strongly Agree

2. Music is essentially an extracurricular activity. Strongly Disagree Disagree Neither Agree nor Disagree Agree Strongly Agree

3. The instructional content of music classes is centered on preparation for public performances. Strongly Disagree Disagree Neither Agree nor Disagree Agree Strongly Agree

4. Music's role in schools is primarily that of providing entertainment.

__ Strongly Disagree __ Disagree __ Neither Agree nor Disagree __ Agree __ Strongly Agree

5. Frequent public performances are an important aspect of a music ensemble.

__ Strongly Disagree __ Disagree __ Neither Agree nor Disagree __ Agree __ Strongly Agree

6. The success of a choir program is determined by the ratings received at competitions.

__ Strongly Disagree __ Disagree __ Neither Agree nor Disagree __ Agree __ Strongly Agree

7. Out-of-state festivals and performances provide music students with enrichment educational opportunities.

_ Strongly Disagree __ Disagree __ Neither Agree nor Disagree __ Agree __ Strongly Agree

8. Music teachers must be certified in music in order to be effective ensemble conductors.

__ Strongly Disagree __ Disagree __ Neither Agree nor Disagree __ Agree __ Strongly Agree

9. Alternative certification negatively impacts the instructor's effectiveness in the music classroom. Strongly Disagree Disagree Neither Agree nor Disagree Agree Strongly Agree

10. Recruitment of ensemble members is an important responsibility of a director.

__ Strongly Disagree __ Disagree __ Neither Agree nor Disagree __ Agree __ Strongly Agree

11. Music ensembles should have repertoire performance-ready in case they are needed to perform with little advance notice.
Strongly Disagree
Disagree
Neither Agree nor Disagree Agree
Strongly Agree

12. Music teachers should be expected to raise funds to alleviate the burden on the school budget.

_ Strongly Disagree Disagree Neither Agree nor Disagree Agree Strongly Agree

13. Instructional content of music classes should be focused on the TEKS. Strongly Disagree Disagree Neither Agree nor Disagree Agree Strongly Agree

14. Music classes should not be considered academic classes.

__ Strongly Disagree __ Disagree __ Neither Agree nor Disagree __ Agree __ Strongly Agree

15. Music teachers should select the literature to be performed by their ensembles.

__ Strongly Disagree __ Disagree __ Neither Agree nor Disagree __ Agree __ Strongly Agree

16. Music teachers should be consulted regarding the scheduling of their classes.

__ Strongly Disagree __ Disagree __ Neither Agree nor Disagree __ Agree __ Strongly Agree 
17. Student placement in music classes should be predicated on the music teacher's recommendation.

Strongly Disagree __ Disagree __ Neither Agree nor Disagree __ Agree __ Strongly Agree

18. Music teachers should receive public and non-public recognition for "a job well done."

_ Strongly Disagree __ Disagree __ Neither Agree nor Disagree __ Agree __ Strongly Agree

\section{PROFESSIONAL ASSISTANCE FOR MUSIC TEACHERS}

A. In terms of professional support of music teachers early in their career, how useful is each of the following in your school setting? Please rate each method of assistance by placing an $\mathbf{X}$ in the appropriate blank.

In-service programs

No help __ Little help __ Moderately helpful __ Very helpful __Extremely helpful _ _ N/A New teacher orientation program

_ No help __ Little help __ Moderately helpful __ Very helpful __Extremely helpful __ N/A Fine arts supervisor

__ No help __ Little help __ Moderately helpful __ Very helpful __Extremely helpful __ N/A Other music teachers in school

_ No help __ Little help __ Moderately helpful _ _ Very helpful __Extremely helpful __ N/A Other non-music teachers in school

__ No help __ Little help __ Moderately helpful __ Very helpful ___Extremely helpful __ N/A

\section{Colleagues in music field}

__ No help __ Little help __ Moderately helpful __ Very helpful __Extremely helpful __ N/A Assigned mentor teacher (non-music)

__ No help __ Little help __ Moderately helpful __ Very helpful __ Extremely helpful __ N/A

\section{Assigned mentor teacher (music)}

__ No help __ Little help __ Moderately helpful _ _ Very helpful __Extremely helpful __ N/A

Music workshops or conferences

__ No help __ Little help __ Moderately helpful __ Very helpful __Extremely helpful __ N/A

Release time to observe experienced music teachers

__ No help __ Little help __ Moderately helpful __ Very helpful __Extremely helpful __ N/A Accessibility of administrator

__ No help __ Little help __ Moderately helpful __ Very helpful ___Extremely helpful __ N/A

\section{Administrators' visits to classroom}

__ No help __ Little help __ Moderately helpful __ Very helpful __Extremely helpful _ _ N/A

\section{Administrative assistance with classroom management}

__ No help __ Little help __ Moderately helpful __ Very helpful __Extremely helpful __ N/A 


\section{Administrative assistance with budget preparation}

_ No help __ Little help __ Moderately helpful __ Very helpful __Extremely helpful __ N/A

Assistance with administrative duties (fundraising, trips, competitions)

_ No help __ Little help __ Moderately helpful __ Very helpful __Extremely helpful __ N/A

Administrative assistance with large classes

_ No help __ Little help __ Moderately helpful __ Very helpful ___Extremely helpful __ N/A

\section{Release time to work with feeder school choirs}

_ No help __ Little help __ Moderately helpful __ Very helpful __ Extremely helpful __ N/A

Release time for performances outside of school

__ No help __ Little help __ Moderately helpful __ Very helpful __Extremely helpful __ N/A

Release time for recruiting students from other schools

No help __ Little help __ Moderately helpful _ _ Very helpful __Extremely helpful _ _ N/A

B. Place an $\mathbf{X}$ next to the methods of assistance that are provided in your school.

In-service programs

New teacher orientation program

Fine arts supervisor

Other music teachers in school

Other non-music teachers in school

Colleagues in music field

Assigned mentor teacher (non-music)

Assigned mentor teacher (music)

Music workshops or conferences

Release time to observe experienced music teachers

Accessibility of administrator

Administrators' visits to classroom

Administrative assistance with classroom management

Administrative assistance with budget preparation

Assistance with administrative duties (fundraising, trips, competitions)

Administrative assistance with large classes

Release time to work with feeder school choirs

Release time for performances outside of school

Release time for recruiting students from other schools 


\section{JOB SATISFACTION}

1. All in all, how satisfied would you say you are with your teaching position? Place an $\mathbf{X}$ next to the appropriate response.

_ 1 - Very dissatisfied

_ 2 - Somewhat dissatisfied

_ 3 - Neither dissatisfied nor satisfied

_ 4 - Somewhat satisfied

_ 5 - Very satisfied

Which of the following (if any) would increase your job satisfaction in your current teaching assignment?

Please place an $\mathbf{X}$ next to all that apply. Place an * (asterisk) next to the primary factor.

Administrative support

Support of other faculty members

Community/Parent support

Higher Salary

Fewer classes

Smaller classes

Improved school environment

Support with discipline problems

Participation in decision making

Recognition of accomplishments

Adequate educational preparation for this teaching assignment

Other (please specify) 


\section{SURVEY OF EARLY CAREER MUSIC TEACHERS}

\section{School Type}

Please place an $\mathbf{X}$ next to the response that best describes your school. Urban Suburban

Rural

1. Within the next year, how likely is it that you will stay in the teaching profession OR leave the teaching profession to go into some different occupation?

Please place an $\mathbf{X}$ next to the appropriate response.

1 - Definitely plan to leave after this year

2 - Likely to leave after this year

3 - Undecided

_ 4 - Likely to stay after this year

_ 5 - Definitely plan to stay after this year

If you plan to LEAVE, answer question \#2.

\section{If you place to STAY, answer question \#3 on the following page.}

2. What is the primary reason affecting your decision to leave the teaching profession?

Please place an $\mathbf{X}$ next to all that apply. Put an * (asterisk) next to you primary reason.

Inadequate administrative support Lack of influence over school policies

Lack of parental/community support

Lack of adequate preparation time

Poor opportunities for advancement

Lack of student motivation

Lack of student discipline

Pursue other music career

Attend graduate school in music

Pursue career outside of music

Elimination of program

Low salary

Isolation

Multi-campus duties

Workload issues

Scheduling issues

Classes too large

Unsafe environment

Reduction in staff

Pregnancy/Child care

Moving

Health

Job stress

Other (Please specify)

\section{If you answered Question \#2, you have completed the survey.}

Thank you for your assistance.

Vicki Baker 
3. What are the reasons affecting your decision to stay in the teaching profession?

Please place an $\mathbf{X}$ next to all that apply. Put an * (asterisk) next to your primary reason.

Administrative support

Influence over school policies

Parental/Community support

Adequate preparation time

Opportunities for advancement

Student motivation

Salary

Student discipline

Workload

Schedule

Class size

Environment

Support of other teachers

Other (Please specify)

4. If you plan to stay in the teaching profession, how likely is it that you will leave your

school to teach somewhere else within the next year?

Please place an $\mathbf{X}$ next to the appropriate response.

1 - Definitely plan to change schools after this year

2 - Likely to change schools after this year

_ 3 - Undecided

4 - Likely to stay at this school after this year

5 - Definitely plan to stay at this school after this year

5. If you plan to leave your school, what is the primary reason affecting your decision to change schools?

Please place an $\mathbf{X}$ next to all that apply. Put an * (asterisk) next to your primary reason.

Inadequate administrative support

Lack of influence over school policies

Lack of parental/community support

Lack of adequate preparation time

Poor opportunities for advancement

Lack of student motivation

Lack of student discipline

Elimination of program

Reduction in staff

Low salary

Other (Please specify)
Job stress

Isolation

Multi-campus duties

Workload issues

Scheduling issues

Classes too large

Unsafe environment

Moving

Pregnancy/Children

You have completed the questionnaire. Thank you for your assistance.

\section{Vicki Baker}


APPENDIX B

EARLY CAREER SECONDARY CHORAL MUSIC TEACHER SURVEY 


\section{EARLY CAREER SECONDARY CHORAL MUSIC TEACHER SURVEY}

Name

School

School Address

School Phone

Home Phone

E-mail

School District Conference $(5 \mathrm{~A}, 4 \overline{\mathrm{A} \ldots 3 \mathrm{C}, 2 \mathrm{C} \ldots})$

Principal's Name

2004-2005 begins your year to teach

How long have you taught at this school?

Total number of people on choral staff at your school

Your position Head director Assistant director

During the Fall, 2004 I will be conducting a research project entitled The Relationship between the Perception of Administrative Support and Job Satisfaction among Secondary Choral Music Educators New to the Profession.

Would you be willing to participate in the project by completing a brief questionnaire?

$$
\text { Yes }
$$

No

Would you be willing to participate in an individual interview regarding your teaching experience?

$$
\text { Yes } \quad \text { No }
$$

Please e-mail your questionnaire to vicki.d.baker@ttu.edu

Thank you for your assistance.

Vicki D. Baker

Ph.D. Candidate - Music Education

Texas Tech University

School of Music

Lubbock, Texas

vicki.d.baker@ttu.edu 
APPENDIX C

UNIVERSITY INTERSCHOLASTIC LEAGUE SCHOOL CONFERENCE POPULATION 


\section{UNIVERSITY INTERSCHOLASTIC LEAGUE SCHOOL CONFERENCE POPULATION}

High School - Grades 9 - 12

Conference

Student Population

A

AA

AAA

AAAA

AAAAA
189 and below

$190-389$

$390-899$

$900-1924$

1925 and above

Junior High School - Grades 7 - 9

Conference

B

BB

BBB
Student Population

$0-249$

$250-649$

650 and above

Middle School - Grades 7 - 8

Conference

$\mathrm{C}$
$\mathrm{CC}$
$\mathrm{CCC}$

$\mathrm{C}$

$\mathrm{CCC}$
Student Population

$0-249$

$250-649$

650 and above

(2004 - 2005 Constitution and Contest Rules) 
APPENDIX D

TEXAS EDUCATION AGENCY

SCHOOL DISTRICT

CATEGORIES 


\section{TEXAS EDUCATION AGENCY \\ SCHOOL DISTRICT \\ CATEGORIES}

\begin{tabular}{ll} 
Category $*$ & Student Population \\
\hline A & 50,000 and over \\
B & 25,000 to 49,999 \\
C & 10,000 to 24,999 \\
D & 5,000 to 9,999 \\
E & 3,000 to 4,999 \\
F & 1,600 to 2,999 \\
G & 1,000 to 1,599 \\
H & 500 to 999 \\
I & Under 500
\end{tabular}

(Snapshot 2002, Texas Education Agency)

* Districts are grouped by size into nine categories based on the number of students in membership. 
APPENDIX E

EARLY CAREER TEACHER QUESTIONNAIRE

COVER LETTER 
Dear (Name of Respondent),

According to the survey that you completed, you have agreed to be a participant in my doctoral dissertation study. I appreciate your willingness to assist me.

Attached is a questionnaire that will take approximately 15 minutes for you to complete. My deadline for collecting the questionnaires is December 17, 2004.

All information retrieved from the questionnaires will remain confidential.

Your principal will also be receiving a questionnaire as a part of my research.

My goal is for this research project to benefit both early career and experienced music educators.

Thank you for your assistance.

Vicki Baker

Doctoral Candidate

Texas Tech University 
APPENDIX F

PRINCIPALS OF EARLY CAREER TEACHERS

COVER LETTER 
December 4, 2004

My name is Vicki Baker and I am a doctoral candidate at Texas Tech University. I am seeking a Ph.D. in Music Education. My dissertation is entitled The Relationship between the Perception of Administrative Support and Job Satisfaction among Early Career Secondary Choral Music Educators.

Studies have found that $50 \%$ of beginning educators in Texas leave the profession by their $5^{\text {th }}$ year of teaching. Research indicates that administrators play a critical role in the both the attrition and retention of educators new to the profession.

Therefore, as part of my dissertation study, I would like to include your view of music education and methods of professional support for new teachers. I have received a questionnaire from the choir teacher at your school and would like to have your response to some of the same questions for comparison.

Attached is a questionnaire that will take approximately 5 minutes for you to complete. My deadline for collecting the questionnaires is December 17, 2004.

All information retrieved from the questionnaires will remain confidential. My goal for this research project is to find ways to insure the longevity of teachers new to the profession.

Thank you for your assistance.

Vicki Baker

Doctoral Candidate

Texas Tech University 
APPENDIX G

OTHER FACTORS LEADING TO GREATER JOB SATISFACTION 


\section{OTHER FACTORS LEADING TO GREATER JOB SATISFACTION}

\section{Subject \#1}

"As a new director at ISD, I spend many hours after school and on weekends with programs and competitions. I know this is part of my job as an extra-curricular teacher, but it is very difficult adequately managing home and work. I feel my own children have suffered because of it. However, I DO like my job and it is rewarding enough to remain here. I am just often torn between the 2 places."

Subject \#3

“Less 'paperwork', more computer accessibility for both me and my students.”

Subject \# 5

"Ownership over the program"

Subject \#8

"Bigger budget"

Subject \#11

"Community/Parent Support and Improved School Environment are both equal components. I'm finding it extremely frustrating to get irresponsible students with irresponsible parents to be accountable for themselves. Very low school morale overall."

Subject \#16

"Not being the assistant."

Subject \#19

"More limited 'duty' assignments, i.e. hall, door gym, cafeteria."

Subject \#36

"Better flexibility and support with benefits administrator." 


\section{Subject \#37}

"An adequate understanding of the importance of sweepstakes award and music education in general would behoove administration. An understanding by administration that removing students from their elective classes in order to 'double dip' them in a core class isn't always in the best interest of the students."

Subject \#39

"More interested students"

Subject \#40

"More schedule input, regulated budget procedures, need team conference time."

Subject \#41

"Feeling more comfortable and prepared by getting more EXPERIENCE"

\section{Subject \#42}

"Administrative help with budget and fundraising, and release time for students to help with recruitment."

\section{Subject \#46}

"Consistency in hone school and maybe change in position from Assistant Director to Head Director, but I'm somewhat satisfied being an assistant."

\section{Subject \#47}

"Students who are raised to respect and are motivated to learn and contribute to the classroom environment instead of take away from it."

\section{Subject \#48}

"I wish I was at 1 school not 2."

Subject \#53

"Being consulted about student placement in certain classes" 


\section{Subject \#54}

"Allowing me to arrange my classes as needed i.e. getting to select the students that go into 'select' choir, placing all boys in one class together if I have four in one class and four in another against $20+$ girls per class. Not using choir as a 'dump' class for students that only need fine arts credit, but do not want to be in a performance-based class.

\section{Subject \#56}

"Budget, instruments, music and other teaching resources make a world of difference."

Subject \#57

"Scheduling is a major problem. I cannot get the students I need in my choir classes. I teach a total of 28 students all day. So, I have turned all classes into choir."

Subject \#60

"A head director who is easier to work with."

Subject \#66

"More ideal classroom. I am split schools, so to be at one school would be much more ideal."

Subject \#72

"More training for at-risk students, behavioral management and much more emphasis on encouragement for me"

Subject \#74

"Restructure middle school feeder programs. Currently choir and orchestra are taught by the same teachers at the middle schools. (Recruitment)"

Subject \#79

"Improved feeder schools (students need to be more adequately prepared)"

Subject \#81

"Help with paperwork/fundraising/etc." 


\section{Subject \#83}

"I am currently asking for more choir classes and to be full-time. I am working full-time to get everything that needs to be done accomplished, but I am only getting paid half-time pay. My principal is behind me, but the administration doesn't realize how things need to be. I am in the process of trying to educate them."

Subject \#87

"Having a boy's choir class." 
APPENDIX H

OTHER REASONS FOR STAYING IN

THE TEACHING PROFESSION 


\section{OTHER REASONS FOR STAYING IN THE TEACHING PROFESSION}

\section{Subject \#1}

"My children will be on campus next year."

Subject \#3

"This year I have a great group of students. IT is such a pleasure for me to teach them after having classes from the $27^{\text {th }}$ level of hell for my first three years. I am still the 'dump' class for my school, but I now have a 'dump' class of my own where I can put those students who have no desire to either perform or be part of a group. This class is general music."

Subject \#8

"Develop my skills to move up in music (HS, college)"

Subject \#17

"I want to try to build, not just quit because some days are tough."

Subject \#18

"The students and how they enjoy choir."

Subject \#21

"Enjoy making a difference in students' lives."

Subject \#22

"Love to teach kids music."

Subject \#31

"Love the students."

Subject \#34

"I love music-that's the ONLY reason I stay." 
Subject \#37

"I will stay because I love the students."

Subject \#41

"Need to stick in one place to gain experience."

Subject \#42

"I enjoy seeing the students learn about music."

Subject \#48

"Because I keep telling myself next year has to be different."

Subject \#52

"I have time to be a good father."

Subject \#59

"Benefits"

Subject \#65

"I want to stay somewhere log enough to build a program that is mine I figure that after three years in one school, I can assess if I feel that teaching really fits me as a permanent career. Also, my husband is VERY supportive of my teaching career. It definitely helps me to have the wonderful family support at home."

Subject \#69

"Mortgage payments"

Subject \#71

"We own a home and I'm the primary provider."

Subject \#83

"I am a teacher for the intrinsic reward of it. I love to teach music and I love kids." 
APPENDIX I

OTHER REASONS FOR CHANGING SCHOOLS 


\section{OTHER REASONS FOR EARLY CAREER TEACHERS INTENDING TO CHANGE SCHOOLS}

Subject \#6

"Wanting to move to a larger city, perhaps a school with older students (High School). Lots of discipline frustrations in Middle School."

Subject \#11

"School closing. Will definitely teach next year, possibly in same district."

Subject \#16

"Opportunity for better position."

Subject \#18

"Increase in stipend."

Subject \#20

"Desire to teach older age group"

Subject \#37

"If our AYP scores do not improve, there is talk that every teacher will be fired or moved to another school. This of course is based on 3 or 4 special ed students who did not test on grade level and the number of regular ed students who showed up to take the math TAKS."

Subject \#58

"I currently teach primarily $9^{\text {th }}$ graders, I would like to teach older students, perhaps even college."

Subject \#66

"Split schools"

Subject \#69

“Too far from my house" 


\section{Subject \#79}

"Not sure if I have what it takes for UIL and teaching in general."

Subject \#83

"Not being full-time." 
APPENDIX J

TRANSCRIPT OF INTERVIEWS 


\section{TRANSCRIPT OF INTERVIEWS}

Subject \#16 - February 9, 2005

Researcher - In your school would you say that you do or do not have community and parent support?

Subject - We have a lot of community and parent support.

R. - Could you please define for me what community and parent support is?

S. - Well, we have parents literally come into the classroom and help us with CPA work, get money organized. They help us with background scenes, settings for the musical. Help get us costumes-many things like that.

R. - Would you say in your school you do or do not have administrative support?

S. - We have great administrative support.

R. - Could you tell me a little bit about ways your administrator supports you?

S. - He's always there for us to go in and talk to if we need to have a chat. He really encourages the fine arts by allowing us to do multiple musicals and go on trips like this and taking a trip to New York we'll be taking and he's even accompanying us on the trip. So, yes, we have a lot of support. And a big budget.

R. - What do you mean by big budget?

S. - We have a nice sized budget that we are allowed to use freely-buy music or whatever is going to better the choir program or music program in general.

R. - Would you say that you do or do not have support of other faculty members at your school?

S. - Oh, yeah, we have support from other faculty members. One of my best friends is the band director. He's always there for me to talk to, and give me help, and, you know, encourages the choir program, as well as the band. And the other faculty members are real excited about what we do because it's not like general education, it's more, you know, kind of fun. They like to be involved in the musical and do things like that with us too.

R. - Would you say that you have a good or a bad school environment? 
S. - We have a great school environment. All the kids are pretty well-behaved. There's few, but it's nothing an inner-city school or anything like that.

R. - Do you plan to stay or leave teaching after this year.

S. - I plan to stay after this year.

R. - And why is that?

S. - 'Cause I enjoy it.

R. - Enjoy teaching?

S. - Yes.

R. - Do you plan to stay or leave your present position after this year?

S. - After this year, I plan to stay for right now.

R. - And why do you plan to stay?

S. - Because I need-I feel like there are things that I still need to learn and things like that.

R. - Thank you. 
Subject \#84 - February 9, 2005

Researcher - Would you say that you do or do not have community and parent support at your school?

Subject - We do have support.

R. - And how would you describe the support that you have at your school?

S. - We have a very good parent support system. Our boosters are very supportive and very active and they are major players in the community so they are good at getting the community involved - kind of a go-between between the school and the community.

R. - Do you or do you not have administrative support?

S. - We have excellent administrative support.

R. - Could you talk about that a little bit?

S. - Well, they are supportive monetarily, they are flexible with schedules and letting kids out of class and giving them opportunities to travel. And they attend performances and let the kids know, they are visible to the kids and let them know that they are there and that they are supporting their program.

R. - How about other faculty members at your school, would you say that they're supportive?

S. - The fine arts, the other fine arts teachers are supportive, the academic teachers, I think we are trying to bridge the gap between the two, because there are few of them that do not understand the importance of the fine arts and that we are actually assisting them in what they do in the classroom, but the principal is kind of helping to smooth that transition.

R. - How about the school environment at your school, would you say it is a good or bad environment?

S. - I think it is a positive environment.

R. - Could you talk about that a little bit? In what way?

S. - I think there is more camaraderie this year because of the new principal. He makes sure that all areas-academics, athletics and the fine arts—are equally supported and equally recognized and that everyone feels that they are working towards a common goal 
and everything they do is important, no matter if it is the head coach of the football team or cosmetology class. Everyone is supported.

R. - Do you plan to stay or leave teaching?

S. - Stay.

R. - And what are your reasons for wanting to stay in teaching?

S. - The students- that would be my number one reason.

R. - Do you plan to stay in your present position?

S. - Yes.

R. - What are your reasons for wanting to stay in your present position?

S. - Again, the students, the principal, and the other teachers that I work with. It's just a good overall situation.

R. - Thank you. 
Subject \#67 - February 10, 2005

Researcher - Do you or do you not have parent and community support for your choir program?

Subject - I feel like I have pretty good parent support for my choir program -the parents here are very good about coming to concerts and being involved in fundraising, etc... The only thing that the parents here lack is the willingness to donate time for chaperoning and volunteering, etc... I also think that it would be nice to have more support from the high school director. She is not very supportive and doesn't get very involved. I would like to think that building up the middle school choir programs would be important to her, but it seems like recruiting comes as an afterthought. I would also appreciate more leadership and direction on her part about what the kids should accomplish by the time they get to high school.

R. - Do you have administrative support?

S. - My principal is EXTREMELY SUPPORTIVE!!! He is willing to help out in any way possible - in the past, he has video-taped concerts, chaperoned UIL trips, driven the bus on choir field trips, and he helps set up and break down my choral shell before and after every concert. I am very lucky to work with someone who is so supportive of the choir.

R. - Do administrators give you the schedule you request?

S. - Yes.

R. - Do you have support from other faculty members?

S. - The other faculty members are somewhat supportive of the program, However, there is one area that I would like to see improve - I would love to see more faculty members attend our concerts.

R. - Is your school environment positive or negative?

S. - I would say very positive. Personally, I feel respected on campus by the kids and other teachers, and I have strong administrative support. Also, I think that in general, my school tries to offer a positive environment for everyone who is here - students and teachers alike. I have never seen a staff that so obviously is interested in educating the "whole child" The kids here have many opportunities to get involved and be a part of something. For example, there are many teacher/student competitions and social activities (tournaments, field trips, etc...) where students can get to know teachers outside of the classroom; there are lots of dances and social events outside of class; and the teachers as a whole are open and available for students before and after school. 
Also, it is obvious that the administration here has a vested interest in trying to improve student achievement and also in increasing parent/community ties to the school. Another example is, this year, all teachers have started printing out weekly progress reports to send home to parents. The progress reports are detailed and list each individual assignment and corresponding grade. The parents have been told at the beginning of the year to expect the progress reports. This way, each parent can see exactly what their student is doing in each class - which classes they are not turning in work, which classes they are struggling in, what their test scores look like, etc.... Although it is a great deal more work for most teachers, I think this is a great system that really shows parents and students that we are interested in keeping the communication open, and are looking out for the best interest of the child. I think that all of this contributes to a positive environment for the students and makes the teachers jobs easier. Also, as a staff, there are many get-togethers and social opportunities for teachers and staff members to get to know one another. Last year, my principal wrote a murder mystery dinner game for the whole staff! (That's just one example.) Overall, this is a really positive place to be.

R. - Do you plan to remain in teaching?

S. - I love teaching. I like the summers off, of course, but more than that, I feel like I am really good at bonding with middle school students (hopefully not a tribute to my own maturity level) and I know that I really care about these kids. It is a profession where no two days are alike, and I enjoy being able to form relationships with my students. I honestly never thought that I would enjoy this career as much as I do, and especially at the middle school age level, however, I surprise myself almost every day by looking forward to the day and to what I am going to do in the classroom. (And surprisingly, I actually miss going to school during the nice long summers!)

R. - Do you plan to stay at your present school next year? Why or why not?

S. - For personal reasons, I am actually possibly moving to the Seattle, Washington area over the summer. If I do not move, of course I will stay at my present school, however, if I do move, (obviously) I will not stay. I can say though, that the "wonderfulness" of my current situation is making the moving decision a very tough choice to make.

R. - Thank you. 
Subject \#24 - February 10, 2005

Researcher - Would you say at your school you do or do not have parent and community support?

Subject - I do have parent and community support. Very active, very helpful support from many of my parents, at least from the more wealthy parents, because I live in a wealthy district. My low socio-economic group is not as active.

R. - And what are some of the specific ways your parents provide support?

S. - I have parent volunteers for concerts and trips, and as far as chaperones, helping put concerts together, publicity, for our pop show they do scenery, help get props together and things like that.

R. - At your school would you say that you do or do not have administrative support?

S. - It depends on the activity. If the activity is just choir, not so much. If it is choir plus other activities, there's a little bit more.

R. - Could you give me more specifics?

S. - For example, at my concerts, I have had concerts where I have not had an administrator show up at all. And then if we do a joint thing with choir and band or choir and drama, we usually have one show up.

R. - Are there any other ways that the administration could you support you and doesn't?

S. - They could support, not in financial way, but in assisting getting equipment and scheduling. Scheduling is a big thing. The last couple of years the scheduling has not been conducive to my program. I would say scheduling is the biggest thing.

R. - And how has it not really worked with your program?

S. - They have cut periods of choir and they have set choir against other large electives like athletics and band which makes it impossible for kids to make choices that they don't want to make.

R. - Would you say that you have support of other faculty members at your school?

S. - I do. I do have a lot of support from faculty members. I have a lot of faculty members who volunteer in all areas to help out with shows and they help with getting my kids to extra rehearsals and if they need extra tutoring before contest and things like that. 
R. - And how would you describe the school environment-is it positive, negative, what?

S. - This year it has been very good, very good. A good community atmosphere, the kids are well-disciplined and on-task.

R. - To what would you attribute the positive environment?

S. - This year I would attribute it to a discipline plan that was put together by the teachers themselves, and we had a lot of discussion about what we felt needed to be done over the summer and changes that were made from last year and it has helped a lot.

R. - Do you plan to stay in teaching or leave teaching?

S. - I plan to stay.

R. - Why?

S. - Honestly, I don't see myself doing anything else. This is what I love to do. No matter what comes up.

R. - Do you plan to stay in your present position?

S. - At the moment I plan to stay in my present position.

R. - Why do you plan to stay?

S: - Location-close to home, I've got a good program started that I would like to finish building, good kids, good parent support, good music faculty around me to be supportive-all of those things.

R. - Thank you. 
Subject \#35 - February 10, 2005

Researcher - Would you say that you do or do not have community and parent support in your school?

Subject - Well, as a whole school environment I would say there is probably not a lot of community support. But we do have quite a few parents that are involved in the choir portion.

R. - Could you describe for me the way parent involvement is used to support your choir program?

S. - If we are going on trips, they help chaperone the trips, they help us when we feed the kids - we feed them a lot - they help us feed the children. You know, if you ever need, we run the All-City contest, and Greg Haugen, the gentleman I work with, he's going to be the Region Chair, so we'll be running All-Region contest, as well, and we get all the parents together and they help us run those contests.

R. - And thinking about administrative support in your school, would you say that you do or do not have administrative support?

S. - I do.

R. - Can you tell me the ways the administration supports the choir program?

S. - They pretty much are behind us in anything that we choose to do, especially this year. We don't actually get administrative support at our concerts. We used to. We used to always have some type of administrator at our concerts but this year we haven't had one come yet. But as far as giving us the schedule we wanted or if we needed to go somewhere, or that kind of thing, they are behind us going and they give us support that way.

R. - How about other faculty members giving you support, would you say that they do or do not support the choir program?

S. - I would say some do and some don't.

R. - Tell me about the people who do support the program, what do they do to help?

S. - They allow children to come to us during advisory classes so we can work with our mixed group. They help us out any way that they can. If we need to know the grades they are willing to give us the grades. And a lot of the people who are helpful or supportive have either had children go through band, choir, and orchestra programs and so they know what it takes, and there are some young ones who have younger children 
that want to have them involved in that kind of thing so they are very interested in what we do and are very helpful. But there are quite a few that don't think we do anything.

R. - Would you say that is the main way that they are not supportive, but just thinking that you don't do anything?

S. - Yea. In other words, just music teachers, just a place for the kids to run around and sing. They don't think that we, I mean they know we go to contest and they know that we get Sweepstakes, but they don't understand what all of that means. They think anyone can go and get whatever. They just don't understand.

R. - Talk to me about your school environment. Would you say you have a positive or negative school environment?

S. - Positive school environment.

R. - To what do you attribute the positive school environment?

S. - A lot of supportive teachers. There is just a welcoming feeling that you get when you walk inside of our school. And there is a lot of PTA involvement. There are always parents up there helping behind the desk and if there is ever anything you need you can ask the PTA. There are a lot of other schools that are built the exact same way as is and walking into the other schools that are built just the same way I just don't feel the warmth that I felt the first time I walked into I had the opportunity to choose where I wanted to go work and that was one of the reasons I chose to go to because of the warm feeling, the atmosphere that school provides.

R. - Do you plan to stay or leave teaching? What are the reasons for your decision?

S. - I plan to stay. I enjoy working with the junior high kids. I just enjoy seeing them enjoy something throughout their day, especially this year when they only have one elective as $7^{\text {th }}$ graders and we are used to them having 2 electives, but it is just so amazing that they have this one class that they enjoy coming to and we have a good time. So, I like to see what they can produce.

R. - Do you plan to stay in your present teaching position?

S. - I do as long as we have the numbers to supply, because this year they doubleblocked math and we are on block scheduling, one of the few junior highs that is that way and they started double-blocking math in seventh grade so they took away one elective and they are going to begin double-blocking it in eighth grade so they are taking away one elective, so, but we have so many electives at our school, we have like nine electives, so I would love to stay if I can, if it happens that way. 
Subject \#63 - February 11, 2005

Researcher - Do you or do you not have parent and community support for your choir program?

Subject - We have a wonderful booster club that helps us out a great deal. They take care of payments, uniforms, fundraisers, etc. I would say the community tends to support the sports programs a little bit more than the music programs here. However, we always have packed houses for all of our concerts (although I think this is all of the parents).

R. - Do you have administrative support?

S. - The administration does support the choir program. Anything that happens at competitions, etc., they send out in an email to all of the teachers. However, there have been huge school wide send offs for all of the sports and band going to state, but never for choir (hmmmm.)

R. - Do administrators give you the schedule you request?

S. - Yes, I know that the head director is satisfied with the schedule given.

R. - Do you have support from other faculty members?

S. - I think so. They are supportive when I see them in the hallways, and they are always understanding when students have to be out of class for performance reasons.

R. - Is your school environment positive or negative?

S. - I think overall the school environment is very positive. The teachers and administrators are very positive people, and create a safe, healthy environment for the students to learn.

R. - How is discipline handled at your school?

S. - It depends on the offense. If it is chewing gum in class or things of that nature, they have a detention with me. If they are tardy to any class more than three times, they have a detention with the school.

R. - Do you plan to remain in teaching? If so, why, if not, why not?

S. - I enjoy it. It fulfills my life, and I hope that I am fulfilling others with the language of music. 
R. - Do you plan to stay at your present school next year? Why or why not?

S. - Nope. Going back to grad school. Ready to continue on with my higher education. 
Subject \#4 - February 11, 2005

Researcher - Can you tell me whether or not you have parent and community support at your school?

Subject - I have some parent support—-the kids who have really committed themselves, they have a lot of support from their parents. We do have a little bit of community support. That is growing as we perform for things, but generally ___ does not have a whole lot of support for the arts. So, that is a struggle and we're working on it and dealing with it the best that we can.

R. - You said that you had some parent support, what ways do parents support you?

S. - When we go to competitions and stuff we have to have parents come and help us, you know, some kind of chaperones, and they are always willing to come and help. They help us decorate for the concerts and that kind of stuff. They do stay involved when we have out of school time things.

R. - And you said that the community really doesn't support the arts very much. What exactly do you mean?

S. - They don't really, like we have a sixth grade choir, well not really a choir, a sixth grade vocal group, and they, every time they perform it's really big and isn't really big anyway, so when they have a big group of kids coming together to sing, they do a lot of pop stuff, but the recordings that they have for it have one track with the people singing and the other track without the people singing and they always perform with the people. And so when they hear true singing, you know, from when they get into the higher grades, they don't appreciate it because it's not loud, they can't hear it as much, and you know, it's not the same kind of stuff that they hear all of the time so they really don't appreciate different genres of music. They just want to hear their one kind of music and that's it. You know, that's what they want to hear so we really don't get a lot of support for the stuff that we should be teaching.

R. - Tell me about administrative support in your school. Would you say that you do or do not have administrative support?

S. - We do have quite a bit of support. They understand that it helps the kids. I mean, they have their struggles as well, but we do have quite a bit of support for music.

R. - In what ways does your administration support music?

S. - We have really bad scheduling. This is just my second year, but last year, we had really, really bad scheduling, and the end of last year, last year I was very successful at UIL Concert/Sightreading and stuff, and so I was like, you know, I would really rather 
have this schedule, and I would really rather do this and they said, "We'll do what we can" and they said they would help us out a lot. I mean they are backed up against the wall with some things but as much as they can do, they usually help us. But we got our own room this year. We had to share it with the band last year and they worked it around where we could have our own room.

R. - Talk to me about fellow faculty member, would you say that they do or do not support you?

S. - When it does not require something that is out of their way, yes, they are very supportive. When it is concerts, there's a few that are already musically inclined and understand where we're coming from, and understand music and they do come and support, or if they have a student that they would particularly like to see succeed, then they come, but very seldom do they come outside of school time. But if it's something during the day, then they will support us.

R. - Are there any of them that volunteer to help with things?

S. - Our art teachers helps out quite a bit. She does most of our decorations and that kind of stuff. They do try to encourage people to support the choir, they just don't actually show them. But the art teacher does quite a bit and there are a few others that are in church choirs and they know the other directors and they kind of support us.

R. - Talk to me about your school environment. Would you say that you have a good or a bad school environment?

S. - We have a lot of low-income kids and so we have a lot of struggle with that. So that is kind of frustrating. And I think a lot of times our school, our district, kind of caters to the children and the parents' whims whether it is legitimate or not. They're kind of like, "Oh, we'll do what you need us to do" and they sometimes do that at the expense of the teachers, so the kids get away with things that they shouldn't at all.

R. - Do you mean in terms of discipline?

S. - Discipline, yeah, noticeably discipline, probably.

R. - Tell me how the large number of low-income children impacts your school.

S. - A lot of times you see that the kids come to school so they can get a meal. They don't care about their success. They are just there to survive. They are just in survival mode. And then there's the others, the select few, that are in the same situation as the others and are coming for a meal, but they kind of cling onto you because they feel that love from you, they feel that support, and they know that they can succeed because they 
are taking our word, you know, they are feeling it inside. They have a little more drive than the other kids.

R. - Do you plan to stay in teaching?

S. - I'm kind of one of those who would rather stay home with my kids. I just had a baby and I would really rather stay home with her until she gets into school. When she starts to school, I would love to come back to school, but right now I feel like my priority is family and home.

R. - When you return to teaching, would your consider coming back to the school where you are now?

S. - I think it depends. I really, really like working with the high school choir director. We just have a good chemistry, we work really well together. She has a personality that is just enough different from mine that she can attract certain students and I can attract certain students. That's really nice. Now this is my first teaching experience and I really haven't had a hard time with it because I work so well with her. I wouldn't mind coming back to this school. The few problems that I have I could deal with because I have such a good time with her and the program is growing and I think that helps too.

R. - Thank you. 
Subject \#74 - February 12, 2005

Researcher - Would you say that you do or do not have community and parent support at your school?

Subject - I do.

R. - Explain to me how the community and parents support you.

S. - When I arrived at this job, the booster club was already established and I get a lot of support from the booster club. Especially the senior parents are really involved. They take on a lot of responsibility, especially with fund raising for scholarships, helping out with the variety show we do once a year. That's it.

R. - Do you or do you not have administrative support at your school?

S. - I do.

R. - Can you tell me how your administration supports you?

S. - Mainly, any concerns that I've needed to be addressed have been addressed quickly and supportably, especially when it comes to area finances or needs of the choral department. I just recently put in a request for two Wenger practice rooms, probably in the range of fifty to sixty thousand dollars by the time remodeling is done and they will be very supportive of that. They have put the paperwork in motion to get that done.

R. - Other than financial support, are there any other ways the administrators show support?

S. - Always a presence, whether it is the principal or assistant principal, always a presence at events, school-wide, not just in choir, but feel very supported at concerts or any presentation that we do throughout the year.

R. - Talk to me about scheduling. Are they supportive of you in terms of your scheduling of choirs?

S. - Yes.

R. - Are other faculty members at your school supportive of the choir program?

S. - Yes, very much so. In a school as large as , the turnover in other areas has been a concern. Knowing teachers in areas other than fine arts has been a challenge. At the beginning of the year-who is that person-I don't know who they are. But especially in the fine arts the teachers have been very supportive. 
R. - And why do you think there has been such a turnover in the other areas?

S. - Honestly, in _ I I feel like it is the growth of the city. Of course, in a metropolitan area there is always going to be a lot of that, but in the North Dallas area, where I am, spouse's jobs would be one of the primary reasons.

R. - How would you describe your school environment?

S. - A relaxed and a tight ship all at the same time. I don't feel-I guess this is going back to administration again, I don't feel like it is micro-managed. I feel like if things are going well the administration knows to step back and let the teachers do what they need to do. The discipline is carried out very swiftly and good. Parental contact is made at many levels - teachers and administrators.

R. - Do you plan to stay in teaching?

S. - I do.

R. - And why is that?

S. - I think the number-one thing has got to be the relationship with the kids, and all of these other factors that we talked about go into that. It has a direct correlation with that. I think if you are having problems with administration, finances, and things like that, it distracts from having time with the kids and letting the music and the kids be the focus of the program, which has to be core and central

R. - Do you plan to stay in your same teaching position next year?

S. - Yes.

R. - What are your reasons?

S. - Right now I think it is the best combination for my experience level, which is just a few years teaching, that I can develop that and feel like I can make a difference in the program, along with learning more administrative aspects. The middle school scheduling is not set up the way I want it to be right now. I think it will be a good learning experience how I will address administrators at the district level to address some of those things-middle school scheduling the way I would like it to be. And the kids are great and it is just rewarding overall. It's a good fit. I don't know how many teachers can say that, especially young, new teachers. 
Subject \#5 - February 12, 2005

Researcher - Could you talk to me a little about parent and community support in your school?

Subject - Well, it is a very important part of a program. Right now, my current year, I am having a lot of difficulty with parent support because the previous situation they were always were allowed to make a lot of decisions for the director and so I have been complained about to my principal several times and the principal supported the parent in both situations. He didn't listen to my side or give me the professional courtesy of respecting my decision.

R. - Could you tell me about those instances with the parents?

S. - Yes. One parent filed a complaint, which I was told was a level-one grievance against me because I moved her daughter to the alto section and she had been singing soprano for the last few years. And I moved her because she loses pitch about C5 where pretty much all soprano parts lie. And so after vocalizing her, myself and my assistant determined that we needed her to sing alto. So we moved her. Her mother went right past me, didn't even speak to me about it, went straight to the principal and complained. Said a bunch of lies basically about what I had said and how I had treated her daughter. And the assistant principal approached me and asked me if I was willing to move her back and I told him, "No, I'm not willing to move her back because I made the decision that was best for the choir." The parent continued to pursue it, went to my principal. The principal said, "Have you talked with Ms. ___ ? and she said, "No," and he said you need to go talk to Ms.___ before anything happens at this level. So we scheduled a conference, told her why I made my decision and she said why she was against it and she said basically, point blank, "Either you move her back or she will quit choir and I will continue this grievance." So I met with my principal after that. He told me that he would not advise me to continue in the process because the school board would not support me because she made a I on a Class 1 solo at State for a soprano. And I explained that they were not classified as soprano, alto, it is treble - tenor bass. And he said the board would not understand that. They would see that she had had success and being as she is a senior they would think it was more important for her to be in the class and continue in a program that she has been in for 5 years than to lose her over something that they would see as insignificant-putting her in a different section. So he told me that some principals will back their teachers no matter what they do but he was not that principal and that if he could not win it at the school board level that we would not support me. He told me to take it home over the weekend and think about what I wanted to do. Pick my battles wisely. He said that I'm new to the district, I'm on a one-year contract and they could choose not to renew it for any reason. And he said that a senior was not worth that battle because she would graduate in the end. So I went home, I called some peers, I 
called some professional people and they pretty much told me that if the principal is not going to support me, be accommodating and then look for another job. Basically. That's the long version.

R. - That's fine. Can you tell me about the other instance that you had difficulty with parents?

S. - I worked with a student quite a bit outside of class to prepare for All-State and the parent was frustrated because I was not allowing the student to work on the music during class. And so she complained before that they had always done all of their All-State music in class and I was not being accommodating. And her daughter had learninglanguage disabilities where she struggled learning and so I made all of these extra rehearsals outside of the school day to help that student. But in the end she still complained that it wasn't enough. But it was kind of resolved because I did make an effort to meet with her-it was just outside of class time.

R. - Apart from these two parents have you had support from the other parents?

S. - I've had support in the sense that after the concert they will come up and say the choir is really improving, we're glad you're here, we appreciate you being here. As far as I sent out booster club stuff and didn't get any response. Basically I have one parent in the booster club and that is a previous parent from the year before who has basically said, "Well, I'm the only one here willing to do something."

R. - Well, I guess you have already addressed the issue of administrative support. Are there any other things that you can say about whether or not your administration supports you?

S. - Just in general when it comes to a parent and that administrator being out there in front of his administrator, that they are going to protect themselves, or at least this administrator is going to look out for himself rather than supporting the program and rather than supporting me. And he told me when he hired me that the expectation was that I would build the program and that it would grow and be successful. And obviously now I feel like how can I have a successful program when I couldn't even voice my students. And I told him that I really didn't feel good about this decision because you have taken all of the power away from me and the parents get to decide who sings what part. He told me that in my handbook at the beginning of the year I need to put in that the director reserves the right to voice students as she sees fit, have the parents sign it and then I have a document that support that choice. A lot of people don't have to do that, but obviously, at this point, in my case, I have no option but to do that.

R. - How would you describe the support of other faculty members at your school? 
S. - I feel that they have been very supportive. They know that the choir program has not been successful and they want to see it successful.

R. - Are there any specific ways that they show support for the program—anything that they do in particular to show support?

S. - I had one send an e-mail to me to tell my students what a wonderful job they did and I hear students say teachers mention how much better the choir is and how they are improving. So that means a lot.

R. - Do your administrators attend your concerts?

S. - At my first concert—two administrators and at the second one—one.

R. - How would you describe the environment at your school—positive or negative?

S. - It is borderline between negative and positive. There's a lot of unresolved issues and it's kind of at a place where they need to have some changes to move forward, so I sense a lot of hostility in the lounge and workroom.

R. - So you are saying that teachers are negative about the environment?

S. - Yes.

R. - Does student discipline play a role in their feelings about their environment?

S. - Yes it does. They feel like the rules continue to change. You know, they post dress code and then they come back two weeks later and say, "Let's do it this way." They tell us to document, document, send them to the office, send them to the office, or you will be held accountable and when you send them to the office the principal will turn around and send them back and say there is not a problem with the dress code. Those kinds of things.

R. - Do you plan to stay in teaching?

S. - Yes, I do.

R. - What is your main reason for planning to stay?

S. - The difficulty that I have experienced is not enough to take away the joy I get from seeing my kids being successful, in spite of everything else.

R. - Are you planning to stay at this school next year? 
S. - As of right now, yes, because I feel like it's my first year and I don't want to give up on it yet.

R. - So you think things will improve where you will gain ownership of your program?

S. - Yes, I think so. I think I will have to be more specific and more legal-minded in everything I send home and in everything I say and do which was not a concern in which was a small community and the parent were like "Is my kid having fun? You're doing a good job? Oh, well." And these parents are a lot more knowledgeable about law and they hold you to everything. So I think it is an opportunity for me to grow as a professional, because if I were to go somewhere else, who is to say that the same problems would not arise? I certainly don't want to appear as if I am someone who hops from job to job. That's not going to reflect positively on me.

R. - Thank you.

S. - Thank you. 